\title{
Surface-Water/Ground-Water Interaction of the Spokane River and the Spokane Valley/Rathdrum Prairie Aquifer, Idaho and Washington
}

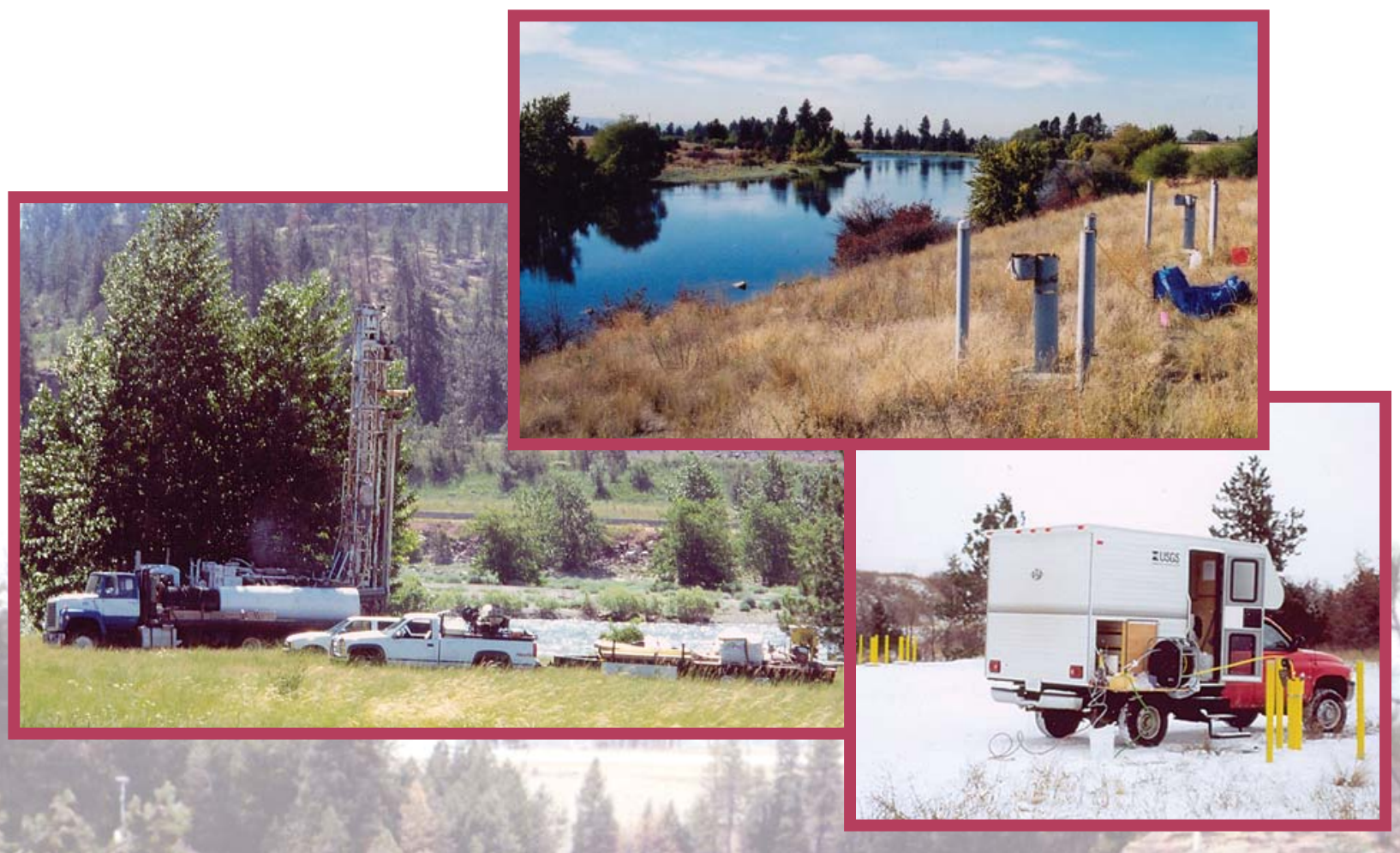

National Water-Quality Assessment Program 
U.S. Department of the Interior

U.S. Geological Survey

Surface-Water/Ground-Water Interaction of the Spokane River and the Spokane Valley/Rathdrum Prairie Aquifer, Idaho and Washington

by Rodney R. Caldwell and Craig L. Bowers

Water-Resources Investigations Report 03-4239

Helena, Montana

October 2003 


\section{U.S. Department of the Interior}

GALE A. NORTON, Secretary

U.S. Geological Survey

Charles G. Groat, Director

Any use of trade, product, or firm name in this publication is for descriptive purposes only and does not imply endorsement by the U.S. Government

For additional information write to:

District Chief

U.S. Geological Survey

3162 Bozeman Avenue

Helena, MT 59601-6456

Copies of this report can be purchased from:

\section{U.S. Geological Survey \\ Information Services \\ Box 25286, Federal Center \\ Denver, CO 80225-0286}

Information regarding the National Water-Quality Assessment (NAWQA) Program is available on the Internet via the World Wide Web using the URL:

http://water.usgs.gov/nawqa 


\section{FOREWORD}

The U.S. Geological Survey (USGS) is committed to serve the Nation with accurate and timely scientific information that helps enhance and protect the overall quality of life, and facilitates effective management of water, biological, energy, and mineral resources (http://www.usgs.gov/). Information on the quality of the Nation's water resources is of critical interest to the USGS because it is so integrally linked to the long-term availability of water that is clean and safe for drinking and recreation and that is suitable for industry, irrigation, and habitat for fish and wildlife. Escalating population growth and increasing demands for the multiple water uses make water availability, now measured in terms of quantity and quality, even more critical to the long-term sustainability of our communities and ecosystems.

The USGS implemented the National WaterQuality Assessment (NAWQA) Program to support national, regional, and local information needs and decisions related to water-quality management and policy (http://water.usgs.gov/nawqa/). Shaped by and coordinated with ongoing efforts of other Federal, State, and local agencies, the NAWQA Program is designed to answer: What is the condition of our Nation's streams and ground water? How are the conditions changing over time? How do natural features and human activities affect the quality of streams and ground water, and where are those effects most pronounced? By combining information on water chemistry, physical characteristics, stream habitat, and aquatic life, the NAWQA Program aims to provide science-based insights for current and emerging water issues and priorities. NAWQA results can contribute to informed decisions that result in practical and effective water-resource management and strategies that protect and restore water quality.

Since 1991, the NAWQA Program has implemented interdisciplinary assessments in more than 50 of the Nation's most important river basins and aquifers, referred to as Study Units (http://water.usgs.gov/ nawqa/nawqamap.html). Collectively, these Study Units account for more than 60 percent of the overall water use and population served by public water supply, and are representative of the Nation's major hydrologic landscapes, priority ecological resources, and agricultural, urban, and natural sources of contamination.

Each assessment is guided by a nationally consistent study design and methods of sampling and analysis. The assessments thereby build local knowledge about water-quality issues and trends in a particular stream or aquifer while providing an understanding of how and why water quality varies regionally and nationally. The consistent, multi-scale approach helps to determine if certain types of waterquality issues are isolated or pervasive, and allows direct comparisons of how human activities and natural processes affect water quality and ecological health in the Nation's diverse geographic and environmental settings. Comprehensive assessments on pesticides, nutrients, volatile organic compounds, trace metals, and aquatic ecology are developed at the national scale through comparative analysis of the Study-Unit findings (http://water.usgs.gov/nawqa/ natsyn.html).

The USGS places high value on the communication and dissemination of credible, timely, and relevant science so that the most recent and available knowledge about water resources can be applied in management and policy decisions. We hope this NAWQA publication will provide you the needed insights and information to meet your needs, and thereby foster increased awareness and involvement in the protection and restoration of our Nation's waters.

The NAWQA Program recognizes that a national assessment by a single program cannot address all water-resource issues of interest. External coordination at all levels is critical for a fully integrated understanding of watersheds and for cost-effective management, regulation, and conservation of our Nation's water resources. The Program, therefore, depends extensively on the advice, cooperation, and information from other Federal, State, interstate, Tribal, and local agencies, non-government organizations, industry, academia, and other stakeholder groups. The assistance and suggestions of all are greatly appreciated.

\author{
Robert M. Hirsch \\ Associate Director for Water
}




\section{CONTENTS}

Foreword

Abstract

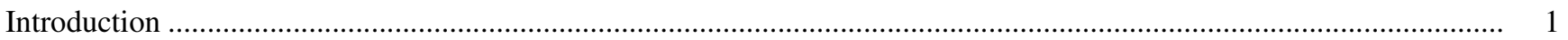

Purpose and Scope

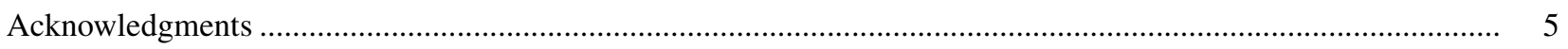

Description of Study Area

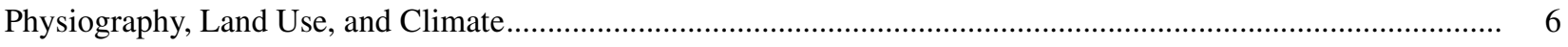

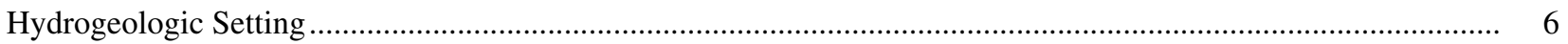

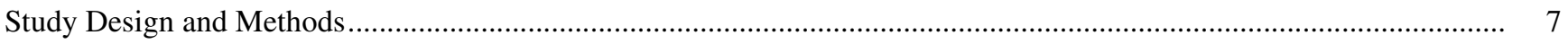

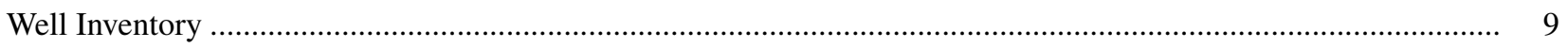

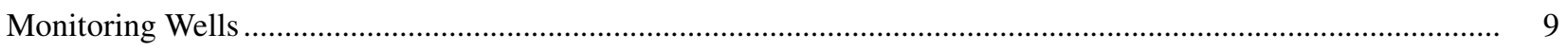

Streamflow and Calculated Losses .................................................................................................... 9

Water-Level, River-Stage, Water-Temperature, and Specific Conductance Monitoring .......................................... 9

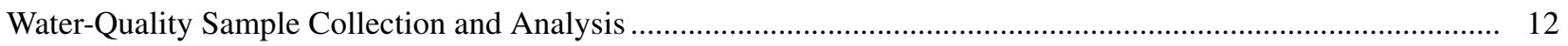

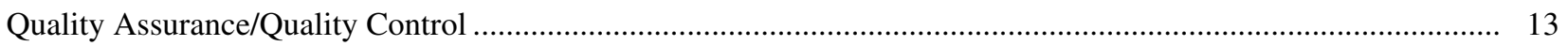

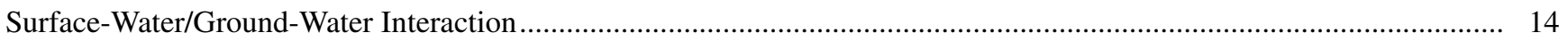

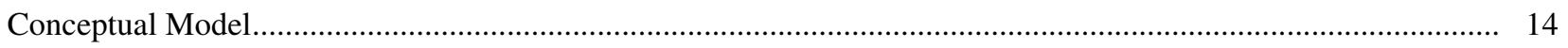

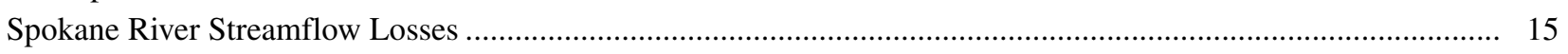

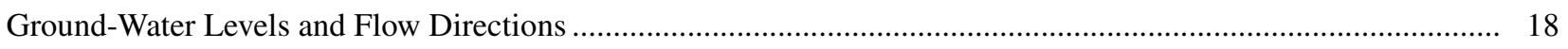

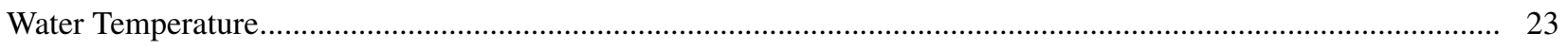

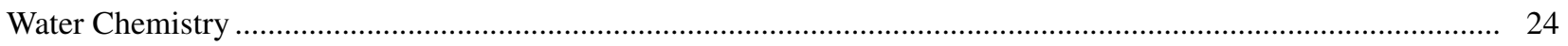

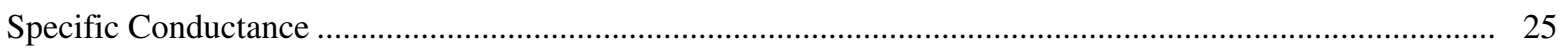

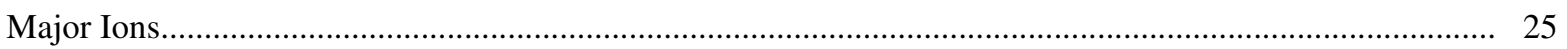

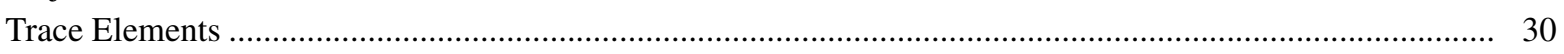

Stable Isotopes

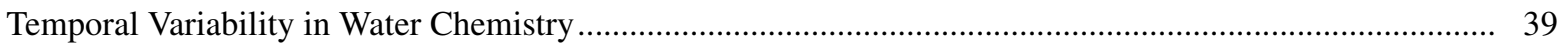

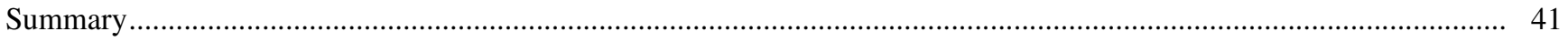

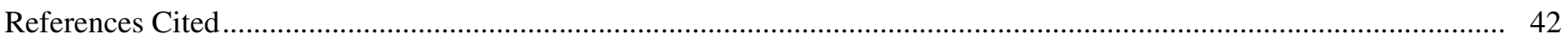

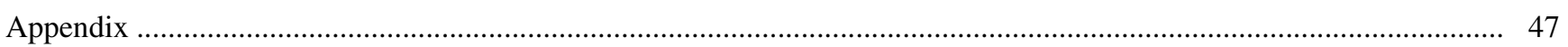

\section{FIGURES}

Figures 1-4. Maps showing:

1. Location of Northern Rockies Intermontane Basins Study Unit, Montana, Idaho, and Washington

2. Location of Spokane Valley/Rathdrum Prairie aquifer and detailed study area of northern Idaho and eastern Washington....

3. Location of monitoring wells and gaging stations in the detailed study area utilized in the surface-water/ground-water interaction study of the Spokane Valley/Rathdrum

Prairie aquifer between Post Falls, Idaho, and Spokane, Washington.

4. Generalized geology and ground-water flow directions of the Spokane Valley/Rathdrum

Prairie aquifer and surrounding basin-fill aquifers

5. Graph showing ground-water and Spokane River sample-collection dates and streamflow

of the Spokane River at Post Falls, Idaho, 1999-2001. 


\section{FIGURES-Continued}

Figure 6. Graph showing Spokane River streamflow and water temperature at Post Falls, Idaho, and calculated streamflow losses between Post Falls, Idaho (station 12419000), and Otis Orchards, Washington (station 12419500), water year 2001

7. Map showing generalized water table of the Spokane Valley/Rathdrum Prairie aquifer between Post Falls, Idaho, and Spokane, Washington

8. Generalized hydrogeologic sections of the Spokane River channel and Spokane Valley/Rathdrum Prairie aquifer showing selected monitoring wells including water levels and inferred water table

9-12. Graphs showing:

9. Spokane River stage, water levels in representative wells, and calculated streamflow loss, water year 2001

10. Generalized hydrologic section showing temperature range of the Spokane River measured at Post Falls, Idaho, and ground water from wells 11 through 16, water year 2001

11. Temperature record of the Spokane River measured at Post Falls, Idaho, and ground water from wells 11 through 16, water year 2001

12. Temperature record of the Spokane River measured at Post Falls, Idaho, and ground water from wells 1, 19, 21, and 22, water year 2001

13. Map showing specific conductance of ground-water samples from the Spokane Valley/

Rathdrum Prairie aquifer, Idaho and Washington .....

14. Trilinear diagram showing major-ion composition of the Spokane River at Post Falls, Idaho, and ground water from 25 monitoring wells from the Spokane Valley/Rathdrum Prairie aquifer between Post Falls, Idaho, and Spokane Washington

15. Map of median dissolved-solids concentrations of samples collected from the Spokane River at Post Falls, Idaho, and ground water classified as river-source, transitional, and regional ground water in the Spokane Valley/Rathdrum Prairie aquifer, Idaho and Washington, 1999-2001.

16. Boxplots summarizing dissolved-solids concentrations of samples collected from the Spokane River at Post Falls, Idaho (water years 1999 through 2001), and ground water identified as river source, transitional, or regional (June 2000 through August 2001) from the Spokane Valley/Rathdrum Prairie aquifer between Post Falls, Idaho, and Spokane, Washington

17. Boxplots summarizing dissolved concentrations of selected trace elements in samples collected from the Spokane River at Post Falls, Idaho, and ground water identified as river source, transitional, or regional from the Spokane Valley/Rathdrum Prairie aquifer between Post Falls, Idaho, and Spokane, Washington, water year 2001

18. Map of dissolved zinc concentrations of samples collected from the Spokane River at Post Falls, Idaho, and ground water from the Spokane Valley/Rathdrum Prairie aquifer between Post Falls, Idaho, and Spokane, Washington, water year 2001

19. Map of median dissolved arsenic concentrations of samples collected from the Spokane River at Post Falls, Idaho, and ground water from the Spokane Valley/Rathdrum Prairie aquifer between Post Falls, Idaho, and Spokane, Washington, water year 2001

20-24. Graphs showing:

20. Dissolved concentrations of cadmium, lead, and zinc in samples collected from the Spokane River at Post Falls, Idaho, and ground water identified as river source from the Spokane Valley/Rathdrum Prairie aquifer between Post Falls, Idaho, and Spokane, Washington, water year 2001 


\section{FIGURES-Continued}

Figure 21. Median dissolved-solids and dissolved zinc concentrations of the Spokane River measured at Post Falls, Idaho, and ground water from wells 11 through 16, water year 2001

22. Relation between $\delta \mathrm{D}$ and $\delta^{18} \mathrm{O}$ in water from the Spokane River and ground water from the Spokane Valley/Rathdrum Prairie aquifer of Idaho and Washington classified as river source, transitional, and regional based on concentrations of dissolved solids, 1999-2001

23. $\delta^{18} \mathrm{O}$ of samples from the Spokane River at Post Falls, Idaho, ground water influenced by recharge from the Spokane River, and regional ground water of the Spokane alley/Rathdrum Prairie aquifer, 1999-2001

24. Dissolved-solids and zinc concentrations of the Spokane River at Post Falls, Idaho, and ground water from selected monitoring wells within the Spokane Valley/Rathdrum

Prairie aquifer between Post Falls, Idaho, and Spokane, Washington, 1999-2001

25. Graphs showing ground-water altitude and water temperature measured in 25 monitoring wells within the Spokane Valley/Rathdrum Prairie aquifer between Post Falls, Idaho, and Spokane, Washington, water year 2001

\section{TABLES}

Table 1. Selected site information for monitoring wells utilized in the surface-water/ground-water interaction detailed study of the Spokane River and the Spokane Valley/Rathdrum Prairie aquifer between Post Falls, Idaho, and Spokane, Washington, 2000-01

2. Trace elements detected in ground-water field blank samples, 2000-01

3. Trace elements with relative percent differences greater than 20 percent or with differences greater than 1 microgram per liter in ground-water replicate sample pairs, 2000-01

4. Monthly mean streamflow, calculated losses, and water temperature of the Spokane River between Post Falls, Idaho, and Spokane, Washington, water years 2000-01

5. Median specific conductance, $\mathrm{pH}$, and major-ion concentrations of the Spokane River and ground water from monitoring wells within the Spokane Valley/Rathdrum Prairie aquifer, 1999-2001

6. Summary of selected trace element data collected from the Spokane River and ground water from monitoring wells within the Spokane Valley/Rathdrum Prairie aquifer, 1999-2001

7. Total-recoverable and dissolved cadmium, lead, and zinc concentrations of ground-water samples from monitoring wells within the Spokane Valley/Rathdrum Prairie aquifer, 2000-01.....

8. Selected trace-element concentrations of the Spokane River at Post Falls, Idaho, and ground water from monitoring wells within the Spokane Valley/Rathdrum Prairie aquifer, 1999-2001 


\section{CONVERSION FACTORS, DATUM, ABBREVIATED WATER-QUALITY UNITS, AND ACRONYMS}

\begin{tabular}{|c|c|c|}
\hline Multiply & By & To obtain \\
\hline \multicolumn{3}{|c|}{ Length } \\
\hline inch & 2.54 & centimeter \\
\hline foot & 0.3048 & meter \\
\hline mile & 1.609 & kilometer \\
\hline \multicolumn{3}{|c|}{ Area } \\
\hline acre & 4,047 & square meter \\
\hline \multicolumn{3}{|c|}{$\underline{\text { Mass }}$} \\
\hline pound & 0.454 & kilogram \\
\hline \multicolumn{3}{|c|}{ Flow } \\
\hline cubic feet per second $\left(\mathrm{ft}^{3} / \mathrm{s}\right)$ & 0.02832 & cubic meter per second \\
\hline gallon per minute & 0.06309 & liter per second \\
\hline \multicolumn{3}{|c|}{ Hydraulic conductivity } \\
\hline foot per day & 0.3048 & meter per day \\
\hline \multicolumn{3}{|c|}{ Transmissivity } \\
\hline foot squared per day & 0.0929 & meter squared per day \\
\hline
\end{tabular}

Temperature can be converted from degrees Celsius $\left({ }^{\circ} \mathrm{C}\right)$ to degrees Fahrenheit $\left({ }^{\circ} \mathrm{F}\right)$ by using the following equation:

$$
\mathrm{F}=9 / 5\left({ }^{\circ} \mathrm{C}\right)+32
$$

Horizontal coordinate information is referenced to North American Datum of 1983 (NAD 83), unless otherwise noted. Vertical coordinate information is referenced to the National Geodetic Vertical Datum of 1929 (NGVD 29).

Abbreviated water-quality units and related terms used in this report:

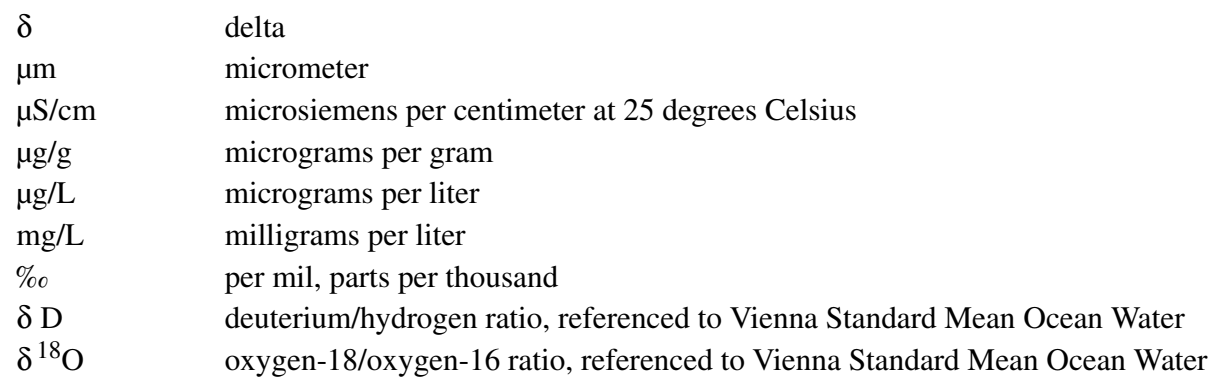

Acronyms used in this report:

$\begin{array}{ll}\text { AL } & \text { U.S. Environmental Protection Agency Action Level } \\ \text { GPS } & \text { Global Positioning System } \\ \text { LHA } & \text { U.S. Environmental Protection Agency Lifetime Health Advisory } \\ \text { LRL } & \text { Laboratory Reporting Level } \\ \text { MCL } & \text { Maximum Contaminant Level } \\ \text { MRL } & \text { Minimum Reporting Level } \\ \text { NAWQA } & \text { National Water-Quality Assessment } \\ \text { NROK } & \text { Northern Rockies Intermontane Basins } \\ \text { PVC } & \text { Polyvinyl Chloride } \\ \text { RPD } & \text { Relative Percent Difference } \\ \text { SDWR } & \text { U.S. Environmental Protection Agency Secondary Drinking-Water Regulation } \\ \text { SVRP } & \text { Spokane Valley/Rathdrum Prairie } \\ \text { USEPA } & \text { U.S. Environmental Protection Agency } \\ \text { USGS } & \text { U.S. Geological Survey } \\ \text { VSMOW } & \text { Vienna Standard Mean Ocean Water }\end{array}$




\title{
Surface-Water/Ground-Water Interaction of the Spokane River and the Spokane Valley/Rathdrum Prairie Aquifer, Idaho and Washington
}

\author{
By Rodney R. Caldwell and Craig L. Bowers
}

\section{ABSTRACT}

Historical mining in the Coeur d'Alene River Basin of northern Idaho has resulted in elevated concentrations of some trace metals (particularly cadmium, lead, and zinc) in water and sediment of Coeur d'Alene Lake and downstream in the Spokane River in Idaho and Washington. These elevated trace-metal concentrations in the Spokane River have raised concerns about potential contamination of ground water in the underlying Spokane Valley/Rathdrum Prairie aquifer, the primary source of drinking water for the city of Spokane and surrounding areas. A study conducted as part of the U.S. Geological Survey's National Water-Quality Assessment Program examined the interaction of the river and aquifer using hydrologic and chemical data along a losing reach of the Spokane River. The river and ground water were extensively monitored over a range of hydrologic conditions at a streamflow-gaging station and 25 monitoring wells situated from 40 to 3,500 feet from the river. River stage, ground-water levels, water temperature, and specific conductance were measured hourly to biweekly. Water samples were collected on nearly a monthly basis between 1999 and 2001 from the Spokane River and were collected up to nine times between June 2000 and August 2001 from the monitoring wells.

Hydrologic and chemical data indicate that the Spokane River recharges the Spokane Valley/ Rathdrum Prairie aquifer along a 17-mile reach between Post Falls, Idaho, and Spokane, Washington. Ground-water levels in the near-river aquifer (less than 300 feet from the river) indicate variably saturated conditions below the river and a ground-water flow gradient away from the losing reach of the river. Calculated monthly mean losses, during water years 2000 and 2001 along a nearly 7-mile reach between two gages, ranged from near 69 to 810 cubic feet per second. Losses generally increased with increased streamflow. However, late summer warm water temperatures also appear to be a factor as losses increased due to lower viscosity as water temperatures increased. Chemical data indicated that river recharge may influence ground-water chemistry as far as 3,000 feet from the river, but ground water within a few hundred feet of the river is most affected. Major-ion concentrations, stable isotopes, and temperature of the river and ground water from near-river wells were similar and exhibited similar temporal trends, whereas ground water from wells located farther from the river generally had higher major-ion concentrations and more stable temperatures and chemistry.

Although trace-element concentrations sometimes exceeded aquatic-life criteria in the water of the Spokane River and were elevated above national median values in the bed sediment, trace-element concentrations of all river and ground-water samples were at levels less than U.S. Environmental Protection Agency drinking-water standards. The Spokane River appears to be a source of cadmium, copper, zinc, and possibly lead in the near-river ground water. Dissolved cadmium, copper, and lead concentrations generally were less than 1 microgram per liter $(\mu \mathrm{g} / \mathrm{L})$ in the river water and ground water. During water year 2001, dissolved zinc concentrations were similar in water from near-river wells $(17-71 \mu \mathrm{g} / \mathrm{L})$ and the river water $(22-$ $66 \mu \mathrm{g} / \mathrm{L}$ ), but were less than detection levels in wells farther from the river. Arsenic, found to be elevated in ground water in parts of the aquifer, does not appear to have a river source. Although the river does influence the ground-water chemistry in proximity to the river, it does not appear to adversely affect the ground-water quality to a level of human-health concern.

\section{INTRODUCTION}

Historical mining activities within the South Fork Coeur d'Alene River Basin (fig. 1) of northern Idaho resulted in large quantities of trace-metal enriched tailings that were placed directly in or along 
streams during ore processing (Long, 1998). These tailings have resulted in elevated trace-metal concentrations in water and sediment within the South Fork Coeur d'Alene River Basin and downstream along and within the Coeur d'Alene River (Spruill, 1993; Bookstrom and others, 2001), the lakebed of Coeur d'Alene Lake (Horowitz and others, 1995; Woods and Beckwith, 1997), and the Spokane River (Maret and Skinner, 2000; Grosbois and others, 2001; Woods, 2001; Beckwith, 2002, 2003; Box and Wallis, 2002) (fig. 1). Maret and Skinner (2000) and Beckwith (2002) reported elevated concentrations of arsenic, cadmium, copper, lead, mercury, and zinc in Spokane River bed sediment. Grosbois and others (2001) reported that streambed sediment (less than the 63 -micrometer $(\mu \mathrm{m})$ fraction) was enriched in some trace elements relative to local background levels, with the maximum enrichment in the upper Spokane River near Coeur d'Alene Lake. Some of the elevated concentrations were high enough to present potential aquatic and human-health problems.

The Spokane Valley/Rathdrum Prairie (SVRP) aquifer is the primary source of drinking water for the rapidly growing population of Spokane, Washington, and nearby communities (fig. 2). The Spokane River recharges the SVRP aquifer in places, and ground water discharges to the river in other places (Drost and Seitz, 1978; Bolke and Vaccaro, 1981; and Gearhart and Buchanan, 2000). Although gaining and losing reaches of the Spokane River have been delineated and gains and losses have been calculated, there are still uncertainties including the quantification of the gains to or losses from the river, temporal variations of gains and losses due to changes in streamflow and (or) groundwater levels, and the conditions (saturated or unsaturated) beneath losing reaches of the river. An increased understanding of the surface-water/ground-water interaction along the Spokane River is needed to address the overall significance of the Spokane River in the water budget and water quality of the SVRP aquifer.

There is concern that the trace elements in the water and sediment of the Spokane River could contaminate the SVRP aquifer. Temporal variations in ground-water chemistry in response to changes in river chemistry and streamflow also are of concern. Zheng (1995) examined water quality of the area and noted that trace-metal concentrations in ground water generally were very low, but also reported consistently high zinc concentrations in the river. Marti and Garrigues (2001) provided baseline data of the physical and chemical influences of the Spokane River on part of the SVRP aquifer in Washington. Cadmium, lead, and zinc were found to be elevated in the near-river ground water, but all concentrations were less than drinkingwater standards. Both Zheng (1995) and Marti and Garrigues (2001) recommended that further study be conducted to better define the interactions between the river and aquifer.

A study of the interaction between the Spokane River and the SVRP aquifer in Idaho and Washington was conducted as part of the Northern Rockies Intermontane Basins (NROK) Study Unit of the U.S. Geological Survey's (USGS) National Water-Quality Assessment (NAWQA) Program (figs. 1 and 2). Specific objectives of this study were to: (1) increase the understanding of the dynamics of the surfacewater/ground-water interaction along the Spokane River; (2) quantify the occurrence, distribution (vertical and areal), and source of trace elements in ground water adjacent to the Spokane River; and (3) investigate temporal variations in ground-water quality in response to fluctuating streamflow and chemistry of the Spokane River. This study was conducted on two general scales: (1) a detailed study of a 17-mile reach of the Spokane River between Post Falls, Idaho, and Spokane, Washington, and the surrounding SVRP aquifer up to 3 miles from the river (fig. 3), and (2) a reconnaissance study of the entire SVRP aquifer (fig. 2) using primarily existing data to provide a hydrogeologic framework to better understand the detailed study area. A small area of basin-fill aquifer extends beyond the established southern boundary of the SVRP aquifer within the detailed study area (fig. 2). For brevity, this area is hereinafter included within the SVRP aquifer in the text and figures regarding the detailed study area.

The NROK Study Unit is located in western Montana, northern Idaho, and northeastern Washington (fig. 1) and is one of more than 50 study units selected for assessment under the NAWQA Program. The major goals of the NAWQA Program are to assess the status and trends of our Nation's water quality, and the natural and human factors that can affect these resources (Gilliom and others, 1995). NAWQA ground-water investigations have focused on waterquality conditions in major aquifers, with an emphasis on recently recharged ground water associated with present and recent human activities (Gilliom and others, 1995). Study activities in the NROK Study Unit began in late 1996. The study area for this report is nested within a regional ground-water quality assessment area (fig. 2) conducted as part of the NAWQA Program (Bowers and others, 2003). 


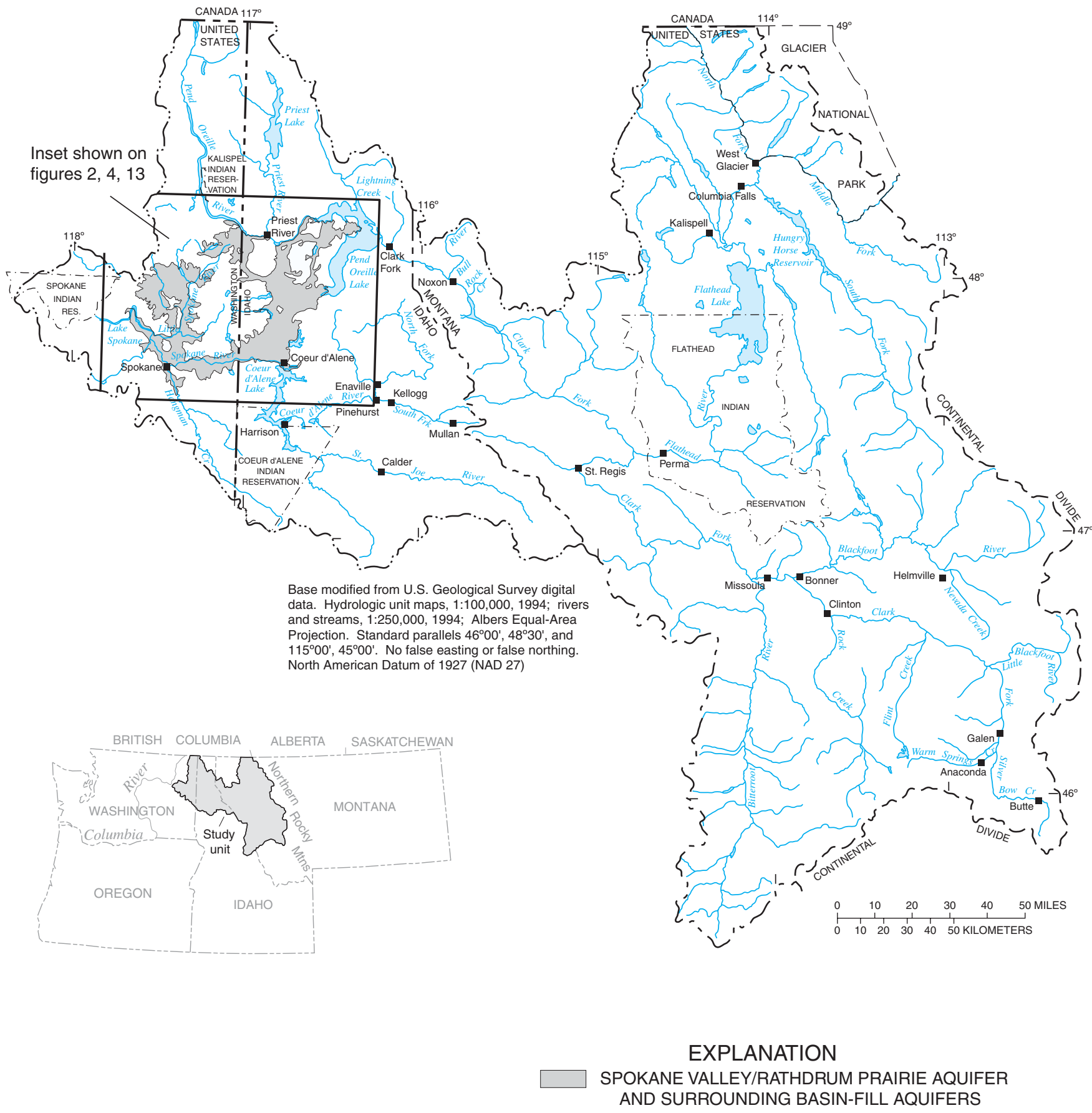

Figure 1. Location of the Northern Rockies Intermontane Basins Study Unit, Montana, Idaho, and Washington. 


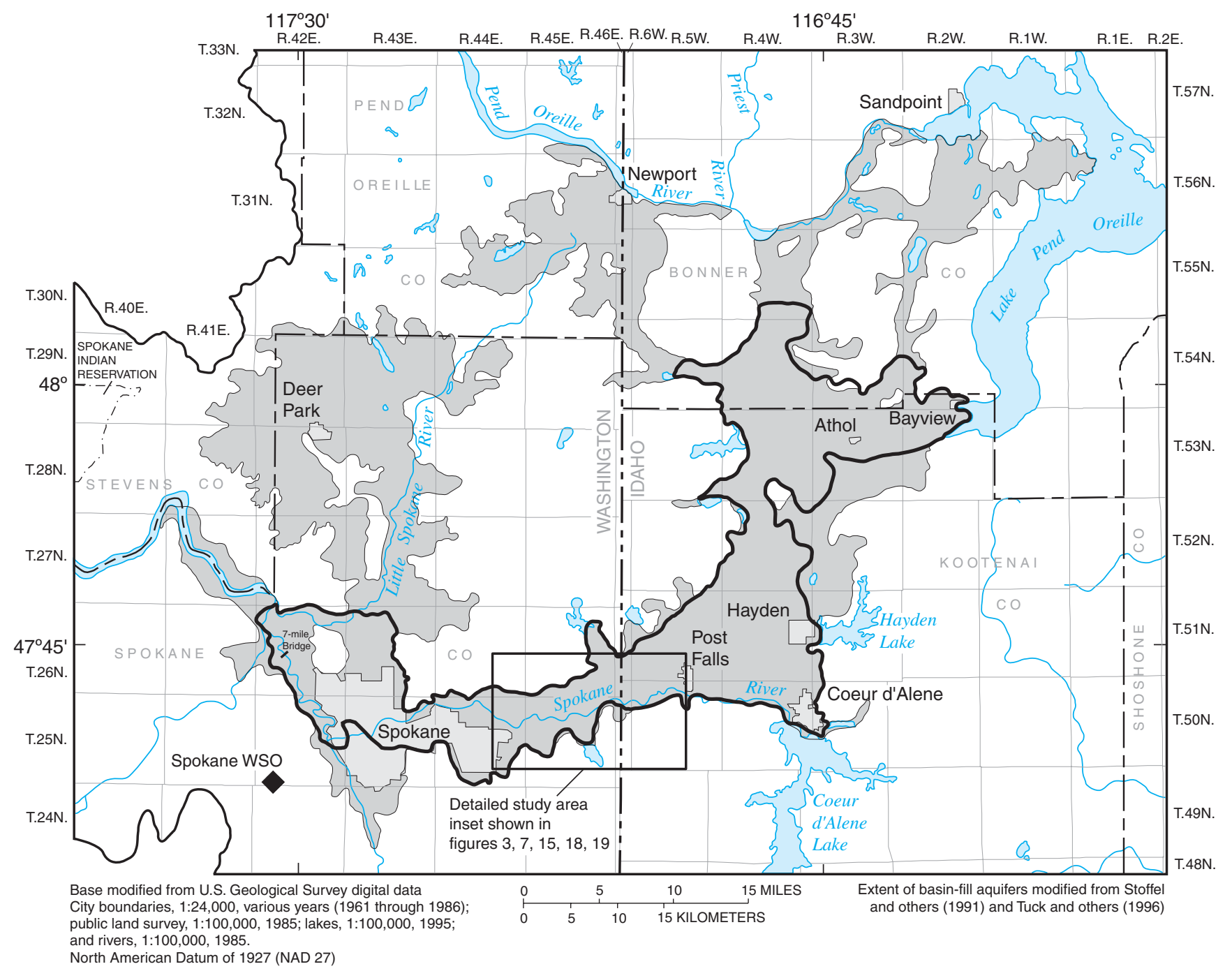

EXPLANATION

GENERAL EXTENT OF BASIN-FILL AQUIFERS. REGIONAL GROUND-WATER QUALITY ASSESSMENT AREA OF BOWERS AND OTHERS (2003)

APPROXIMATE BOUNDARY OF SPOKANE VALLEY/

RATHDRUM PRAIRIE AQUIFER

Spokane WSO

WEATHER STATION AND NAME

Figure 2. Location of Spokane Valley/Rathdrum Prairie aquifer and detailed study area of northern Idaho and eastern Washington. 


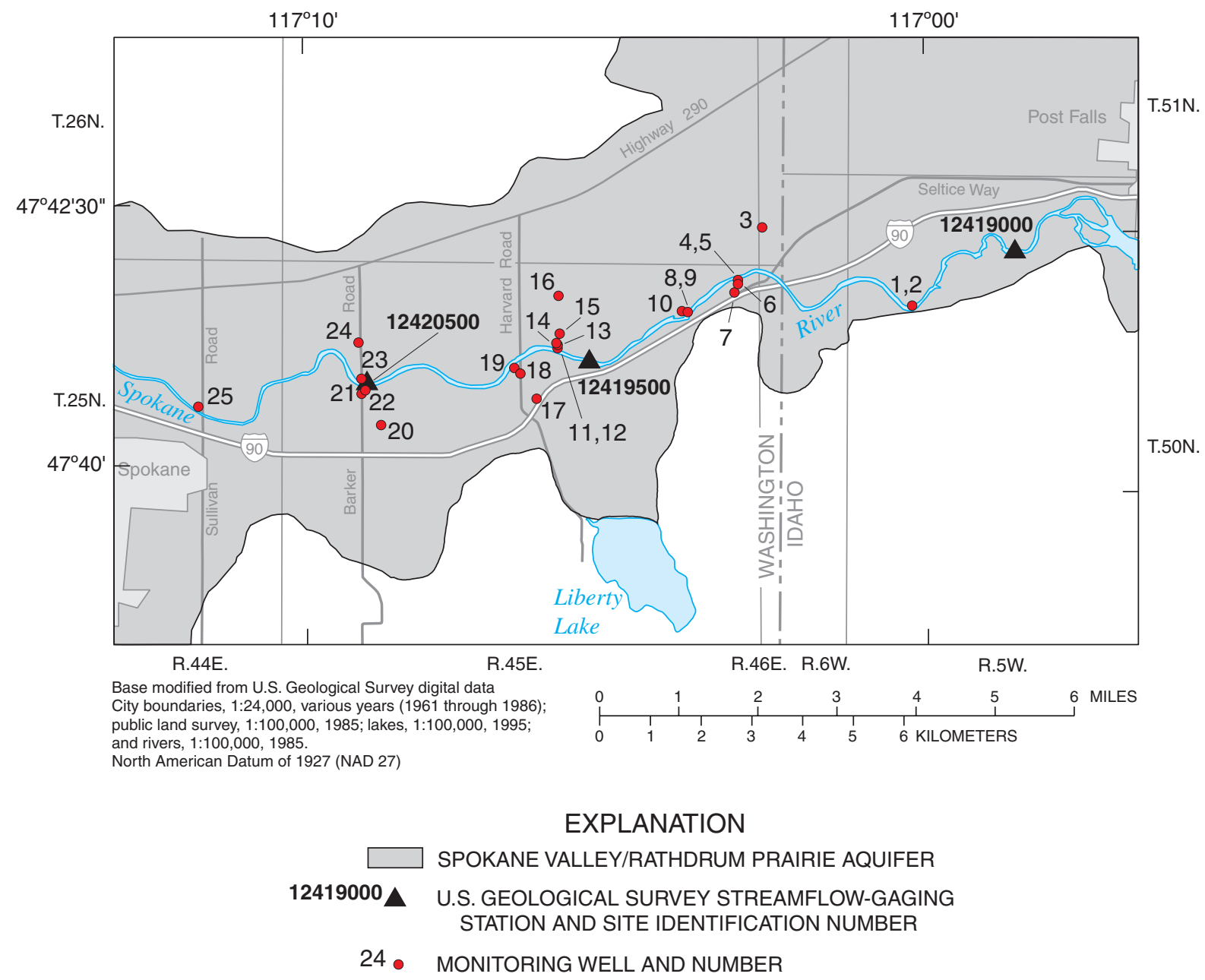

Figure 3. Location of monitoring wells and gaging stations in the detailed study area utilized in the surface-water/ground-water interaction study of the Spokane Valley/Rathdrum Prairie aquifer between Post Falls, Idaho, and Spokane, Washington.

\section{Purpose and Scope}

The purpose of this report is to describe the magnitude and extent of influence of the Spokane River on ground-water flow and chemistry of the SVRP aquifer in Idaho and Washington (fig. 2). The surfacewater/ground-water interactions are described using a variety of hydrologic information including calculated streamflow losses from the Spokane River, groundwater levels measured in a network of observation wells, and water-temperature and water-chemistry data from surface and ground water. This report presents results of hydrologic and chemical measurements and sampling conducted between March 1999 and August 2001.

\section{Acknowledgments}

The authors gratefully acknowledge the local well owners for access to their wells for data collection. The study would not have been possible without the support of David and Nancy Traner, Inland Empire Paper Company, Liberty Lake Sewer and Water District, University of Idaho Research Park, Consolidated Irrigation District, Washington State Parks and Recreation Commission, and the Washington Department of Transportation for allowing us to drill wells on their property. Stan Miller, Reanette Boese, and Beatrice Lackaff of the Spokane County Public Works Department, and John Roland and John Covert of the Washington Department of Ecology were helpful with 
local support and knowledge of the area. Jerry Simms and Jim McLefresh of the Spokane County Public Works Department were extremely gracious with their time and equipment to assist in surveying altitudes of several area wells. Thanks to USGS personnel Fred A. Bailey, Rick L. Backsen, C. Lee Chambers, Angela Frandsen, Karen L. Payne, and Galen J. Schuster for help in the field on this project. A special thanks goes to USGS hydrologic technician Keith L. Hein, who spent many days in the field on every aspect of this study.

\section{DESCRIPTION OF STUDY AREA}

The study area is included within eastern Washington and northern Idaho (fig. 2). The most extensive data collection occurred along a 17-mile reach of the Spokane River between Post Falls, Idaho, and Spokane, Washington, and the surrounding SVRP aquifer up to 3 miles from the river (fig. 3). The primary drinkingwater resource in the area is the SVRP aquifer, which supplies water to over 400,000 people (Idaho Department of Environmental Quality, 2000). The U.S.

Environmental Protection Agency (USEPA) designated the aquifer as a Sole Source Aquifer as defined under section 1424(e) of the Safe Drinking Water Act of 1974 (U.S. Environmental Protection Agency, 2000). The USEPA defines such an aquifer as one that supplies at least 50 percent of the drinking water consumed in the area overlying the aquifer (U.S. Environmental Protection Agency, 2000). People depending on a Sole Source Aquifer generally do not have a viable alternative drinking-water source.

\section{Physiography, Land Use, and Climate}

The SVRP aquifer underlies a relatively flat, alluvium-covered valley. Land-surface altitudes in the valley range from about 1,900 to nearly 2,400 feet above the National Geodetic Vertical Datum of 1929 (NGVD 29). The valley is surrounded by bedrock highlands. Several lakes are located along the margins of the aquifer, the largest of which are Coeur d'Alene Lake and Lake Pend Oreille in Idaho. The valley generally is void of perennial streams other than the Spokane and Little Spokane Rivers.

Ground-water use in the area is primarily public supply, irrigation, commercial, industrial, and domestic (U.S. Geological Survey, 2001). Primary land-cover types overlying the aquifer in the area include agricul- ture and urban (Nakagaki, Hitt, and McNamara, U.S. Geological Survey, written commun., 2001). The uplands surrounding the aquifer area primarily are covered with coniferous forests and residential housing. Agricultural land use consists predominantly of hay, wheat, grass seed, barley, oats, and pasture. Cities in the area include parts of the Spokane metropolitan area in Washington and Coeur d'Alene and Post Falls in Idaho. Residential and commercial development is rapidly increasing in the area as evidenced between the 1990 and 2000 censuses, with a 16-percent population increase in Spokane County, Washington, and nearly a 56-percent increase in Kootenai County, Idaho (U.S. Census Bureau, 2002).

The climate throughout the study area varies from subhumid to semiarid with warm, dry summers and cool, moist winters (Molenaar, 1988). Mean annual (1961-1990) precipitation was 16.5 inches per year at the Spokane WSO Airport (Western Regional Climate Center, 1998) (fig. 2). Most of the precipitation falls as snow during the 5-month period from November through March (Molenaar, 1988).

\section{Hydrogeologic Setting}

The Spokane River is the only surficial outflow of Coeur d'Alene Lake. The river flows out of the northern end of Coeur d'Alene Lake and then westward into the alluvium-covered valley and through the city of Spokane, Washington. Between the lake and the IdahoWashington State line, the river flows adjacent to bedrock uplands to the south or through narrow bedrock channels in places. Near the Idaho-Washington State line and westward, the river flows through a relatively narrow valley incised within the alluvium. Flow from Coeur d'Alene Lake into the Spokane River is regulated by a set of dams at Post Falls; therefore, streamflow below the dams does not always represent the concurrent inflows to the lake. During normal years, the dam gates are usually open between December and June, and streamflow rises during the spring snowmelt and subsides in June. During most of the summer, the dam gates are set to maintain specific water levels in Coeur d'Alene Lake. Because of below-average precipitation and reduced inflow to the lake during water year 2001 (October 1, 2000, through September 30, 2001), the gates were closed earlier than usual to maintain lake levels. From late September through December, the gates typically are incrementally opened 
to lower the lake to its natural level (Box and Wallis, 2002). The Spokane River at Post Falls has been gaged by the USGS since 1913.

The SVRP aquifer (fig. 4) is composed of unconsolidated coarse-grained sand, gravel, cobbles, and boulders primarily deposited by a series of catastrophic glacial outburst floods during the Pleistocene Epoch (Molenaar, 1988). The sediment deposited in this highenergy depositional environment is coarser grained than is typical for most basin-fill deposits, resulting in one of the most productive aquifers in the United States (Molenaar, 1988). Although much of the area includes the coarse-grained flood deposits of high permeability, fine-grained sedimentary material of lower permeability is present locally. The aquifer is underlain and laterally bounded by relatively impermeable metamorphic, igneous, sedimentary, and metasedimentary bedrock of Precambrian to Tertiary age, which is exposed as highlands at several locations (fig. 4). Although some water-supply wells are completed in the bedrock, these units are not considered to be major aquifers.

The saturated thickness of the SVRP aquifer is not well defined, but is reported to range from less than 50 feet in places along the aquifer margin and northwest of Spokane to more than 400 feet in the central part of the aquifer near the Idaho-Washington State line east of Spokane, Washington (Bolke and Vaccaro, 1981; Gerstel and Palmer, 1994). Depth to water ranges from less than 50 feet along the Spokane River near Spokane to more than 400 feet below land surface near Athol, Idaho (Bolke and Vaccaro, 1979; Berenbrock and others, 1995; Briar and others, 1996; and Stone and others, 1996). The slope of the water table generally reflects the local surface topography, resulting in a general southward direction of ground-water flow from the area near the southern end of Lake Pend Oreille, towards the city of Coeur d'Alene, and then westward towards the city of Spokane (Drost and Seitz, 1978; Molenaar, 1988). Most of this ground water either discharges to the Spokane and Little Spokane Rivers or is withdrawn by wells (Drost and Seitz, 1978; Molenaar, 1988). Generalized ground-water flow directions in the SVRP aquifer are illustrated in figure 4. Recharge to the aquifer occurs by infiltration of precipitation, irrigation water and septic tank effluent, subsurface inflow from adjoining highlands and tributary valleys, and leakage from adjacent and overlying surface-water sources (Molenaar, 1988).
Wells completed in the saturated coarse-grained deposits rarely extend more than 100 feet into the saturated zone, but can yield several thousand gallons per minute (Bolke and Vaccaro, 1979; Stone and others, 1996). Estimated transmissivity values range from several thousand to several million feet squared per day, with estimated ground-water velocities exceeding 60 feet per day in some areas (Drost and Seitz, 1978).

Several investigations reported that water from the Spokane River recharges the SVRP aquifer in places. Piper and La Rocque (1944) noted that the stage in the upper reach of Spokane River to a point 4 miles west of the Idaho-Washington State line (near Spokane) appeared to be higher than the regional water table. More recently, Gearhart and Buchanan (2000) examined the hydraulic connection between the Spokane River and the aquifer. They concluded that the river had a losing reach between Post Falls and near Spokane (the Barker Road bridge, fig. 3) with unsaturated flow conditions between the river and aquifer. From the Barker Road bridge downstream to the Sullivan Road bridge (fig. 3), the river was transitional as it varied from losing to gaining based on periodic measurements of ground-water levels and river stage.

\section{STUDY DESIGN AND METHODS}

The primary focus of the study described in this report was to examine the influence of surface water on ground water in the SVRP aquifer in areas where the Spokane River loses streamflow. The first step in the study was to use historical gaging-station and ground-water level data to determine which reaches of the Spokane River likely lose water to the groundwater system. These reaches were identified from information collected during an inventory of existing wells and from streamflow-gaging records. Once the losing reaches were identified, the following methods were used in a detailed study of the near-river area to examine and quantify the surface-water/ground-water interaction. Monitoring wells were installed in areas with no existing wells, particularly in areas near the Spokane River. River stage, ground-water levels, specific conductance, and water temperature were monitored. Water-chemistry samples were collected over a range of streamflow conditions. USGS datacollection and processing procedures were followed for quality control/quality assurance. 


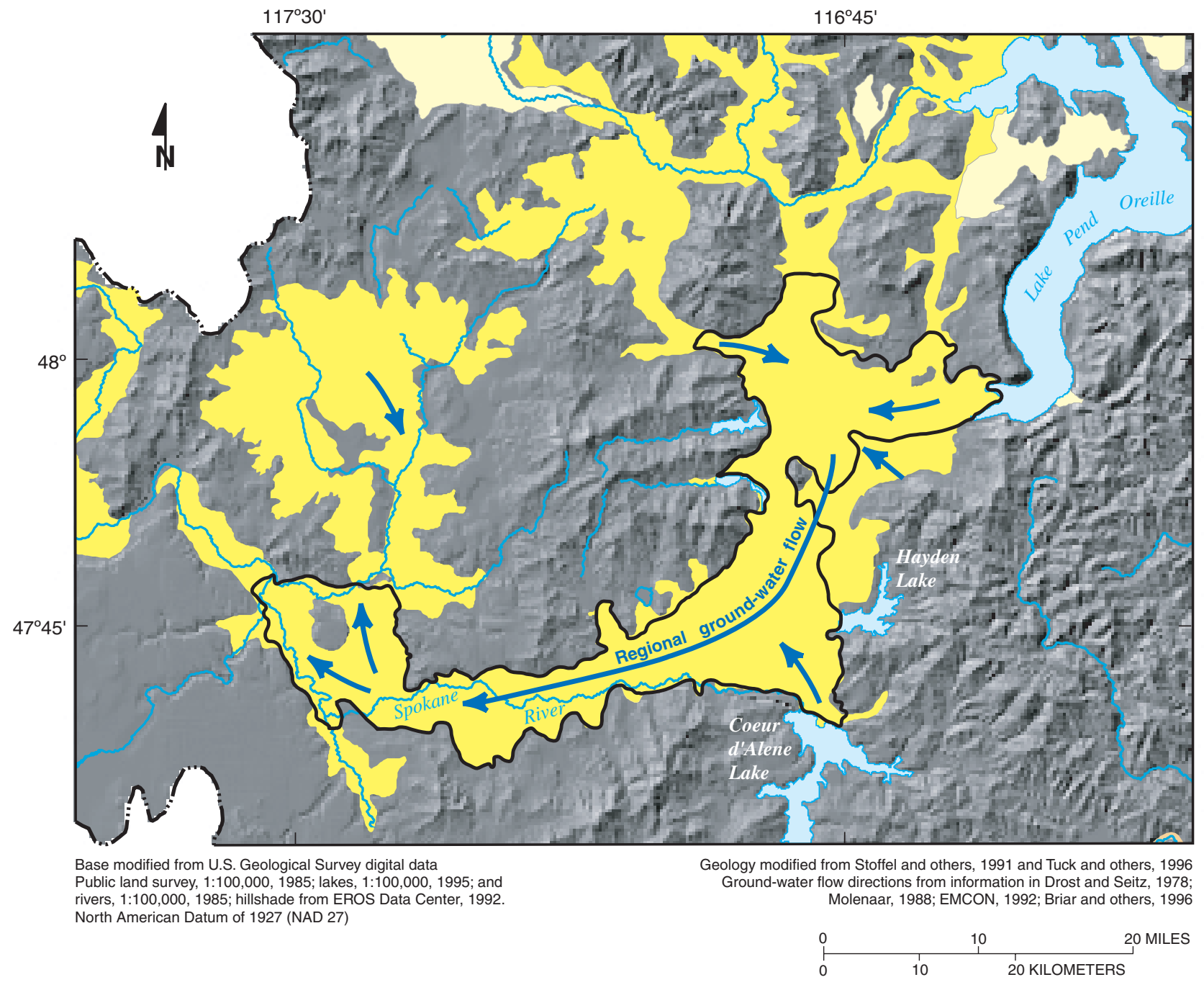

EXPLANATION

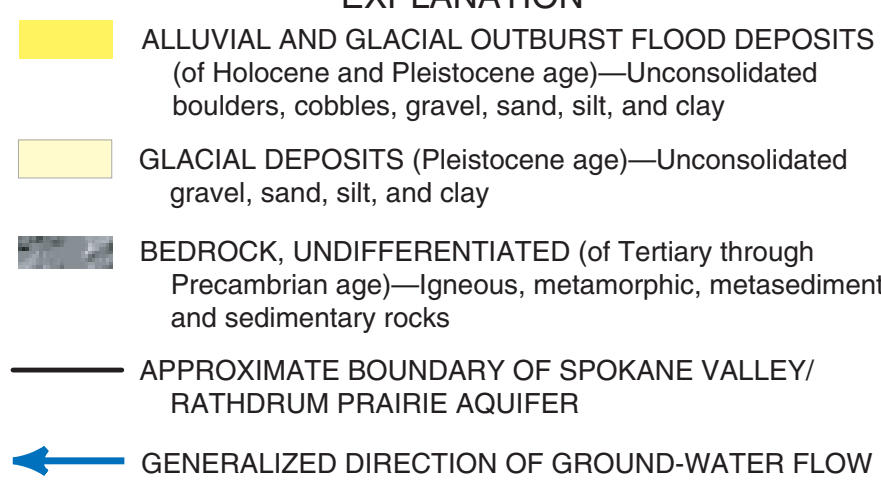

Figure 4. Generalized geology and ground-water flow directions of the Spokane Valley/Rathdrum Prairie aquifer and surrounding basinfill aquifers. 


\section{Well Inventory}

One spring and 111 existing domestic, irrigation, public supply, and monitoring wells were inventoried between August 1999 and January 2001 (Bowers and others, 2003). Locations were determined using global positioning system (GPS). Most land-surface altitudes of the wells (especially wells near the Spokane River) were determined using standard differential leveling procedures or with GPS equipment with accuracies of less than 1 foot. Land-surface altitudes of some wells farther from the river were interpreted from USGS 7.5minute topographic maps with accuracies generally less than 10 feet. Synoptic measurements of water levels and specific conductance for the inventoried wells and spring were made to help determine the local groundwater flow regime and to further refine the extent of the losing reaches of the Spokane River. Water levels were measured to an accuracy of 0.01 foot. Specific conductance was measured in samples collected as near as possible to the well head.

\section{Monitoring Wells}

Twenty-five monitoring wells were utilized for this study (table 1), 18 of which (wells 1, 2, 4-19) were installed between June and September 2000. The newly installed wells filled spatial and vertical gaps in the existing well network, especially close to the river (fig. 3). Pre-existing wells (wells 3, 20-25) were drilled between 1996 and 1998. Newly installed wells were located at various distances from the river in five general locations where the Spokane River was suspected of recharging the aquifer. These wells were installed at various depths below the water table. Four sets of nested well pairs (wells 1 and 2, 4 and 5, 8 and 9, 11 and 12) were completed at different depths to examine the vertical distribution of water levels and water chemistry (fig. 3). All wells consisted of 2-inch diameter polyvinyl chloride (PVC) casing, with PVC screen lengths of 5 to 10 feet (wells drilled for this study) or 30 to 40 feet (pre-existing wells) set at the bottom of the wells. Wells installed for this study were drilled with an air rotary drill rig and had 6-inch diameter steel casing driven to temporarily keep the hole open. Silica sand was placed from the bottom of the borehole to about 5 feet above the top of the screen. About 1 foot of bentonite pellets were placed immediately on top of the sand, and the remainder of the annulus was filled with bentonite grout. The temporary steel casing was incrementally pulled out as the sand and bentonite material was placed in the annulus between the PVC and steel casing.

\section{Streamflow and Calculated Losses}

Differences in streamflow between USGS streamflow-gaging stations on the Spokane River were used to determine the amount of leakage in the river reach between Post Falls, Idaho, and the eastern city limits of Spokane, Washington (fig. 3). This section of the river potentially loses water to the underlying aquifer at all times because the water-table altitude in the area is lower than the river surface.

Measurement errors in streamflow for the Post Falls, Idaho (station 12419000), and Otis Orchards, Washington (station 12419500) gages determined from the stage-discharge relation for each station are estimated to be within \pm 5 percent. Measurements at the Greenacres, Washington gage (station 12420500) have an estimated error of up to \pm 10 percent based on hydrologic conditions (Galen Schuster, U.S. Geological Survey, oral commun., 2002).

\section{Water-Level, River-Stage, Water- Temperature, and Specific Conductance Monitoring}

Ground-water level, water temperature, and specific conductance were measured hourly to biweekly in the 25 monitoring wells (fig. 3). Water level, specific conductance, and temperature were manually measured biweekly at all wells. Water levels were measured to an accuracy of 0.01 foot with an electric or steel tape. Temperature and specific conductance were measured downhole or during sample collection in a flow-through cell. Pressure transducers were installed in 10 monitoring wells to record water levels hourly. Sixteen monitoring wells were instrumented to record water temperatures hourly. Specific conductance, temperature, and river stage (gage height) of the Spokane River near the Post Falls (station 12419000, fig. 3) gage were recorded hourly during water year 2001. 
Table 1. Selected site information for monitoring wells utilized in the surface-water/ground-water interaction detailed study of the Spokane River and the Spokane Valley/Rathdrum Prairie aquifer between Post Falls, Idaho, and Spokane, Washington, 2000-01

[All wells are screened within Quaternary-age alluvium glacial-outburst flood deposits and constructed of 2-inch diameter polyvinyl chloride casing. Remarks: W, instrumented with digital water-level recorder; T, instrumented with digital temperature recorder; NR, no recorder installed]

\begin{tabular}{|c|c|c|c|c|c|}
\hline $\begin{array}{c}\text { Well } \\
\text { number } \\
\text { (fig. 3) }\end{array}$ & $\begin{array}{l}\text { Location } \\
\text { number }^{1}\end{array}$ & $\begin{array}{c}\text { Site } \\
\text { identification } \\
\text { number }\end{array}$ & $\begin{array}{r}\text { Latitude }^{2} \\
\text { (degrees, }\end{array}$ & Longitude $^{2}$ & $\begin{array}{c}\text { Altitude of } \\
\text { land surface } \\
\text { (feet above } \\
\text { NGVD 29) }\end{array}$ \\
\hline 1 & 50N05W07DABC01 & 474134117002201 & 474134.3 & 1170022.4 & $2,069.46$ \\
\hline 2 & 50N05W07DABC02 & 474134117002202 & 474134.6 & 1170022.3 & $2,070.32$ \\
\hline 3 & 26N46E31CBBC01 & 474226117024801 & 474225.6 & 1170248.1 & $2,090.20$ \\
\hline 4 & 25N45E01ABDD01 & 474151117031101 & 474150.7 & 1170310.8 & $2,035.41$ \\
\hline 5 & 25N45E01ABDD02 & 474151117031102 & 474150.7 & 1170310.8 & $2,035.27$ \\
\hline 6 & 25N45E01ABDD03 & 474149117031101 & 474149.4 & 1170311.5 & $2,034.90$ \\
\hline 7 & 25N45E01ACAD01 & 474144117031401 & 474144.2 & 1170314.1 & $2,045.75$ \\
\hline 8 & 25N45E01CBBD02 & 474130117035902 & 474130.1 & 1170358.8 & $2,025.02$ \\
\hline 9 & 25N45E01CBBD01 & 474130117035901 & 474130.1 & 1170358.8 & $2,024.89$ \\
\hline 10 & 25N45E01CBBC01 & 474131117040401 & 474130.9 & 1170403.5 & $2,031.22$ \\
\hline 11 & 25N45E10BAAA01 & 474106117060501 & 474106.3 & 1170605.0 & $2,030.62$ \\
\hline 12 & 25N45E10BAAA03 & 474107117060502 & 474106.6 & 1170605.2 & $2,031.47$ \\
\hline 13 & 25N45E10BAAA02 & 474107117060501 & 474107.3 & 1170604.9 & $2,036.51$ \\
\hline 14 & 25N45E03CDDD01 & 474110117060601 & 474109.6 & 1170605.8 & $2,033.10$ \\
\hline 15 & 25N45E03CDDA01 & 474115117060301 & 474115.1 & 1170603.1 & $2,040.18$ \\
\hline 16 & 25N45E03BDDA01 & 474140117060401 & 474140.2 & 1170604.3 & $2,052.57$ \\
\hline 17 & 25N45E10CBDA01 & 474033117062501 & 474033.5 & 1170625.2 & $2,037.95$ \\
\hline 18 & 25N45E09ADAD01 & 474050117064201 & 474050.4 & 1170641.7 & $2,023.05$ \\
\hline 19 & 25N45E09ADAB01 & 474053117064701 & 474053.5 & 1170646.6 & $2,021.28$ \\
\hline 20 & 25N45E17BBAA05 & 474016117085601 & 474015.5 & 1170855.8 & $2,035.60$ \\
\hline 21 & 25N45E08CBBC02 & 474037117091301 & 474037.2 & 1170913.1 & $2,018.00$ \\
\hline 22 & 25N45E08CBBC01 & 474038117091201 & 474038.2 & 1170912.0 & $2,017.50$ \\
\hline 23 & 25N45E07ADDD01 & 474046117091501 & 474045.5 & 1170914.9 & $2,001.50$ \\
\hline 24 & 25N45E07AAAA04 & 474109117091701 & 474109.3 & 1170917.1 & $2,021.70$ \\
\hline 25 & 25N44E11DDAC01 & 474026117115301 & 474025.6 & 1171153.2 & $1,965.90$ \\
\hline
\end{tabular}

\footnotetext{
${ }^{1}$ Described in the appendix.

${ }^{2}$ Referenced to North American Datum of 1983 (NAD 83).
} 


\begin{tabular}{|c|c|c|c|c|c|c|c|}
\hline \multirow{2}{*}{$\begin{array}{c}\text { Depth of } \\
\text { well } \\
\text { (feet below } \\
\text { land surface) }\end{array}$} & \multirow{2}{*}{$\begin{array}{c}\text { Top of } \\
\text { casing } \\
\text { (feet above } \\
\text { land surface) }\end{array}$} & \multicolumn{2}{|c|}{ Screened interval } & \multirow{2}{*}{$\begin{array}{c}\text { Approximate } \\
\text { distance from } \\
\text { Spokane River } \\
\text { (feet) }\end{array}$} & \multirow[b]{2}{*}{ County } & \multirow[b]{2}{*}{ State } & \multirow[b]{2}{*}{ Remarks } \\
\hline & & $\begin{array}{c}\text { Top } \\
\text { (feet below } \\
\text { land surface) }\end{array}$ & $\begin{array}{c}\text { Bottom } \\
\text { (feet below } \\
\text { land surface) }\end{array}$ & & & & \\
\hline 79.3 & 2.6 & 69.0 & 79.0 & 100 & Kootenai & Idaho & $\mathrm{W}, \mathrm{T}$ \\
\hline 45.8 & 2.8 & 35.4 & 45.4 & 100 & Kootenai & Idaho & $\mathrm{W}, \mathrm{T}$ \\
\hline 151 & 1.7 & 112 & 147 & 2,700 & Spokane & Washington & NR \\
\hline 74.3 & 2.3 & 63.9 & 73.9 & 40 & Spokane & Washington & $\mathrm{W}, \mathrm{T}$ \\
\hline 60.7 & 2.8 & 55.3 & 60.3 & 40 & Spokane & Washington & NR \\
\hline 77.8 & 2.7 & 67.4 & 77.4 & 130 & Spokane & Washington & $\mathrm{T}$ \\
\hline 86.9 & 2.8 & 76.4 & 86.4 & 700 & Spokane & Washington & $\mathrm{T}$ \\
\hline 32.9 & 2.7 & 22.6 & 32.6 & 80 & Spokane & Washington & $\mathrm{W}, \mathrm{T}$ \\
\hline 76.1 & 2.7 & 65.8 & 75.8 & 80 & Spokane & Washington & $\mathrm{W}, \mathrm{T}$ \\
\hline 71.0 & 2.9 & 60.6 & 70.6 & 400 & Spokane & Washington & $\mathrm{T}$ \\
\hline 71.6 & 2.6 & 61.2 & 71.2 & 100 & Spokane & Washington & $\mathrm{W}, \mathrm{T}$ \\
\hline 136.7 & 2.8 & 126.3 & 136.3 & 100 & Spokane & Washington & $\mathrm{W}, \mathrm{T}$ \\
\hline 75.5 & 2.7 & 65.1 & 75.1 & 200 & Spokane & Washington & $\mathrm{T}$ \\
\hline 88.8 & .0 & 78.4 & 88.4 & 475 & Spokane & Washington & $\mathrm{W}, \mathrm{T}$ \\
\hline 97.5 & .2 & 87.1 & 97.1 & 900 & Spokane & Washington & $\mathrm{T}$ \\
\hline 117.3 & 2.7 & 107.0 & 117.0 & 3,500 & Spokane & Washington & $\mathrm{W}, \mathrm{T}$ \\
\hline 97.1 & 2.6 & 86.8 & 96.8 & 2,600 & Spokane & Washington & NR \\
\hline 77.4 & 2.9 & 67.0 & 77.0 & 640 & Spokane & Washington & $\mathrm{T}$ \\
\hline 70.9 & 2.7 & 60.5 & 70.5 & 80 & Spokane & Washington & $\mathrm{W}, \mathrm{T}$ \\
\hline 113 & 2.2 & 82.5 & 112.5 & 2,500 & Spokane & Washington & NR \\
\hline 98 & 1.6 & 61 & 96 & 200 & Spokane & Washington & NR \\
\hline 97 & 2.2 & 62 & 97 & 100 & Spokane & Washington & NR \\
\hline 80 & .0 & 40 & 80 & 100 & Spokane & Washington & NR \\
\hline 100 & 1.7 & 70 & 100 & 2,500 & Spokane & Washington & NR \\
\hline 67 & 1.3 & 26 & 66 & 100 & Spokane & Washington & NR \\
\hline
\end{tabular}




\section{Water-Quality Sample Collection and Analysis}

Periodic water-quality samples were collected from 25 monitoring wells and the Spokane River at Post Falls to investigate temporal and spatial variations in water chemistry with stream-stage fluctuation (fig. 5). Monitoring wells were sampled as many as eight times between June 2000 and August 2001 (fig. 5). All samples were collected using documented NAWQA sampling procedures (Shelton, 1994; Koterba and others, 1995). Prior to sampling each well, the water level was measured to the nearest 0.01 foot with an electric or steel measuring tape. Samples were collected after a minimum of three well-bore volumes were purged and after field measurements of $\mathrm{pH}$, dissolved oxygen, temperature, turbidity, and specific conductance had stabilized. Samples were collected from the monitoring wells using a 1.75-inch diameter stainless-steel submersible pump with Teflon impellers, tubing, and valves and stainless-steel connections.

Spokane River samples were collected approximately monthly between March 1999 and August 2001 (fig. 5) using depth and width-integrated sampling techniques. Sampling procedures are described in more detail by Bowers and others (2003).

Samples were analyzed for physical properties and major ions, trace elements, and stable isotopes. Physical properties measured onsite included water temperature, dissolved oxygen, $\mathrm{pH}$, specific conductance, and turbidity. Samples for analysis of alkalinity and dissolved major ions and trace elements were filtered onsite through a 0.45 - $\mu \mathrm{m}$ pore-size capsule filter. Both filtered and total-recoverable (whole-water, unfiltered) samples were collected at some sites to examine the potential of colloidal transport of trace elements to and through the aquifer. All samples were processed in the field within 1 hour of sample collection. Alkalinity, major-ion, and trace-element samples were analyzed at the USGS National Water-Quality Laboratory (Denver, Colo.) by various methods (Fishman and Friedman, 1989; Faires, 1993; Fishman, 1993; McLain, 1993; Hoffman and others, 1996; Garbarino and Struzeski, 1998; Garbarino, 1999; Jones and Garbarino, 1999). Alkalinity of selected samples also was determined in the field using the incremental titration method (Wilde and Radtke, 1998).

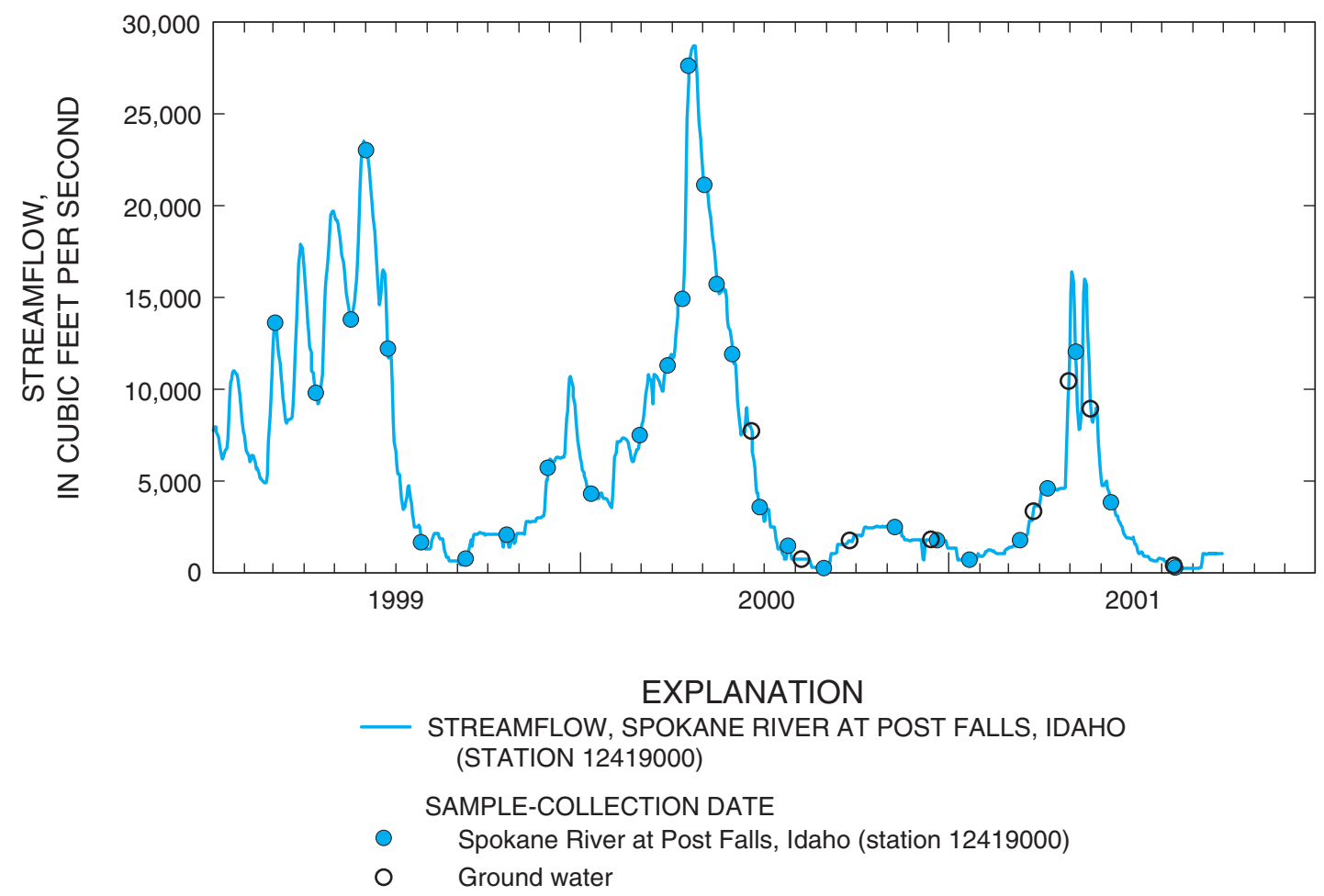

Figure 5. Ground-water and Spokane River sample-collection dates and streamflow of the Spokane River at Post Falls, Idaho, 1999-2001. 
Selected samples were analyzed for the isotopic ratios of ${ }^{2} \mathrm{H} / \mathrm{H}$ and ${ }^{18} \mathrm{O} /{ }^{16} \mathrm{O}$ to investigate the use of the relatively conservative tracers to distinguish between ground water with a Spokane River source and ground water from the regional ground-water flow system. Values are reported as delta $(\delta) \mathrm{D}\left(\right.$ deuterium, $\left.{ }^{2} \mathrm{H}\right)$ and $\delta^{18} \mathrm{O}$ in comparison to the standard reference composition of Vienna Standard Mean Ocean Water (VSMOW), where $\delta$ is expressed in units of per mil (\%o, parts per thousand). The $\delta \mathrm{D}$ analyses were performed using a hydrogen equilibrium technique (Coplen and others, 1991), and the $\delta^{18} \mathrm{O}$ analyses were performed using a carbon dioxide equilibrium technique (Epstein and Mayeda, 1953) at the USGS Isotope Laboratory (Reston, Va.). Water-quality and isotopic data for all water samples are listed in Bowers and others (2003).

\section{Quality Assurance/Quality Control}

Quality-assurance/quality-control procedures consisted of collection and analysis of field blanks and replicates to evaluate the accuracy and precision of the analytical results. Procedures used for collecting quality-assurance samples are described in Koterba and others (1995) and Mueller and others (1997). Qualityassurance samples comprised about 10 percent of the samples and were collected, preserved, and analyzed using the same equipment, procedures, and analytical methods as the environmental samples. In addition, internal quality-assurance practices are performed systematically at the USGS National Water Quality Laboratory (Pritt and Raese, 1995). Quality-assurance data collected for this study are included in Bowers and others (2003).

Field blanks were analyzed for trace elements and used to evaluate potential contamination from the cleaning of equipment, sampling procedures, and/or laboratory analysis. Trace elements were detected infrequently in blanks, and when detected, concentrations generally were very low, indicating that field and laboratory procedures generally did not introduce contamination into the environmental samples. Trace-element concentrations in a field blank from the Spokane River at Post Falls during water year 2001 were all less than reporting levels. A summary of trace elements detected in ground-water blank samples (at concentrations greater than estimated values) are listed in table 2 .

Replicate ground-water samples were analyzed for major ions and trace elements to assess variability in results caused by sample-collection procedures and laboratory analysis. Results of the replicate samples indicate good agreement, with the greatest relative percent differences (RPDs) generally occurring when sample concentrations were low. The RPDs for major ions were less than 10 percent. Trace element RPDs generally were less than 20 percent and/or concentrations were less than 1 microgram per liter $(\mu \mathrm{g} / \mathrm{L})$ different between replicate pairs. Exceptions included some analyses of dissolved aluminum and boron, and total-recoverable iron, manganese, and zinc (table 3). In general, the replicate data indicate an acceptable level of precision for most analyses. No replicate samples were collected from the Spokane River near Post Falls for this study.

Table 2. Trace elements detected in ground-water field blank samples, 2000-01

[ $\mu \mathrm{g} / \mathrm{L}$, micrograms per liter; $\mu \mathrm{m}$, micrometer; MRL, minimum reporting level; LRL, laboratory reporting level; e, estimated value, $<$, less than]

\begin{tabular}{|c|c|c|c|c|c|}
\hline Constituent & $\begin{array}{c}\text { Number } \\
\text { of } \\
\text { blanks }\end{array}$ & $\begin{array}{c}\text { Number of } \\
\text { blanks with } \\
\text { detectable } \\
\text { concentrations }\end{array}$ & $\begin{array}{l}\text { MRL or LRL of } \\
\text { environmental } \\
\text { samples } \\
(\mu \mathrm{g} / \mathrm{L})\end{array}$ & $\begin{array}{c}\text { Highest blank } \\
\text { concentration } \\
(\mu \mathrm{g} / \mathrm{L})\end{array}$ & $\begin{array}{c}\text { Range of } \\
\text { concentrations in } \\
\text { ground-water } \\
\text { samples } \\
(\mu \mathrm{g} / \mathrm{L})\end{array}$ \\
\hline Boron $-0.45-\mu \mathrm{m}$ filtration & 8 & 2 & 2.0 to 13 & 2.5 & $<2.0$ to 25 \\
\hline Cobalt $-0.45-\mu \mathrm{m}$ filtration & 8 & 1 & 0.02 to 1.0 & .03 & $\mathrm{e} 0.01$ to 0.18 \\
\hline Copper $-0.45-\mu \mathrm{m}$ filtration & 8 & 2 & 0.20 to 1.0 & .35 & $<0.20$ to 7.4 \\
\hline Nickel $-0.45-\mu \mathrm{m}$ filtration & 8 & 1 & 0.06 to 1.0 & .21 & $<0.06$ to 9.8 \\
\hline Zinc $-0.45-\mu \mathrm{m}$ filtration & 8 & 1 & 1 & 2.0 & $<1.0$ to 71 \\
\hline Zinc - whole water & 1 & 1 & 1 & 1.1 & $<1.0$ to 74 \\
\hline
\end{tabular}


Table 3. Trace elements with relative percent differences greater than 20 percent or with differences greater than 1 microgram per liter in ground-water replicate sample pairs, 2000-01

[RPD, relative percent difference; $\mu \mathrm{g} / \mathrm{L}$, micrograms per liter; <, less than; >, greater than; --, not applicable]

\begin{tabular}{|c|c|c|c|c|c|}
\hline & $\begin{array}{c}\text { Aluminum, } \\
\text { dissolved }\end{array}$ & $\begin{array}{l}\text { Boron, } \\
\text { dissolved }\end{array}$ & $\begin{array}{l}\text { Iron, total } \\
\text { recoverable }\end{array}$ & $\begin{array}{l}\text { Manganese, } \\
\text { total } \\
\text { recoverable }\end{array}$ & $\begin{array}{l}\text { Zinc, total } \\
\text { recoverable }\end{array}$ \\
\hline Number of replicate samples & 10 & 10 & 3 & 3 & 3 \\
\hline $\begin{array}{l}\text { Number of RPDs }{ }^{1} \text { exceeding } 20 \text { percent } \\
\text { or differences between replicate pairs } \\
\text { of greater than } 1 \mu \mathrm{g} / \mathrm{L}\end{array}$ & 3 & 2 & 1 & 1 & 1 \\
\hline Environmental sample $(\mu \mathrm{g} / \mathrm{L})$ & 5.0 & 11 & 133 & 9.3 & 43 \\
\hline Replicate sample $(\mu \mathrm{g} / \mathrm{L})$ & $<1.0$ & $<7.0$ & 78 & 5.6 & 32 \\
\hline $\mathrm{RPD}^{1}$ & $>133$ & $>44$ & 52 & 50 & 29 \\
\hline Environmental sample $(\mu \mathrm{g} / \mathrm{L})$ & 3.9 & $<7.0$ & -- & -- & -- \\
\hline Replicate sample $(\mu \mathrm{g} / \mathrm{L})$ & $<1.0$ & 9.8 & -- & -- & -- \\
\hline $\mathrm{RPD}^{1}$ & $>118$ & $>\mathbf{3 3}$ & -- & -- & -- \\
\hline Environmental sample $(\mu \mathrm{g} / \mathrm{L})$ & $<1.0$ & -- & -- & -- & -- \\
\hline Replicate sample $(\mu \mathrm{g} / \mathrm{L})$ & 4.6 & -- & -- & -- & -- \\
\hline $\mathrm{RPD}^{1}$ & $>129$ & -- & -- & -- & -- \\
\hline
\end{tabular}

${ }^{1}$ Relative percent difference equals the difference between concentrations of environmental and replicate samples divided by the average of concentrations of the environmental and replicate samples. Concentrations less than reporting levels were set equal to reporting levels for RPD calculation.

\section{SURFACE-WATER/GROUND-WATER INTERACTION}

The conceptual model of the interaction of the Spokane River and SVRP aquifer and the results from this study are presented in this section. The conceptual model describes the basic dynamics of the relation between surface water and ground water in an unconfined-aquifer setting. Calculated streamflow losses, water-table mapping, ground-water hydraulic gradients, ground-water level and river-stage fluctuations, and water-temperature data are discussed to improve the understanding of the surface-water/ground-water interaction of the study area. Results of the waterquality monitoring are discussed with regard to the effect, area of influence, and temporal variability of water leaking from the Spokane River on the water quality of the SVRP aquifer.

\section{Conceptual Model}

The conceptual model for the losing section of the Spokane River between Post Falls and Spokane is either that the river is separated from the ground-water system by an unsaturated zone or that the zone beneath the river is saturated and the hydraulic gradient from the river to the aquifer is steep. The streambed of the Spokane River along this reach is composed primarily of cobbles and boulders (Box and Wallis, 2002). Below the surface of the streambed, the coarse material contains interstitial fine silt and clay (Box and Wallis, 2002). The fine-grained material, some of which may have been transported with the leaking water from the river, likely reduces the permeability of the streambed and underlying substrate. This zone of reduced permeability acts as a leaky layer between the river and the underlying aquifer. 
When the altitude of the river stage is higher than altitudes of ground-water levels in the nearby area, water flows from the river to the aquifer (a losing reach). Conversely, when the altitudes of ground-water levels are higher than the altitude of the river stage, water flows from the aquifer to the river (a gaining reach). The rate at which water flows between the river and the aquifer is dependent upon several factors including the hydraulic properties of the streambed and adjoining aquifer, the depth of penetration of the river into the aquifer, and the hydraulic gradient between the river and aquifer. Leakage to or from a river is computed using principles of Darcy's Law as follows (from Prudic, 1989):

$$
Q=\operatorname{CSTR}(\mathrm{Hs}-\mathrm{Ha})
$$

where

$Q=$ leakage to or from the aquifer through the streambed (length ${ }^{3} /$ time );

$H s=$ hydraulic head in the stream (length);

$H a=$ hydraulic head in the aquifer side of the streambed (length); and

CSTR = conductance of the streambed (length ${ }^{2} /$ time$)$, which is the hydraulic conductivity $(\mathrm{K})$ of the streambed (length/time) multiplied by the product of the width of the stream and its length divided by the thickness of the streambed.

When the water table is below the streambed, unsaturated conditions exist below the river, and leakage from the river is unaffected by the hydraulic head in the aquifer. In other words, the amount of leakage from the river remains the same regardless of how far the water table is below the river bottom. Therefore, if unsaturated conditions exist beneath the river, $\mathrm{Ha}$ is equal to the altitude of the river bottom in equation 1. Also, increased streamflow corresponds to a greater area of submerged streambed, resulting in increased streambed conductance (CSTR) and leakage.

The occurrence and magnitude of fluctuations in ground-water levels in response to changes in river stage are indicators of the relation between the ground water and the river. Ground-water level fluctuations indicate varying rates of recharge and discharge (change in storage); a rise in ground-water levels indicates at least a temporary rate of recharge that exceeds the rate of discharge. A ground-water level rise in response to an increase in river stage is consistent with increased recharge to the aquifer from river leakage. Therefore, water-level fluctuations in the near-river aquifer in response to changes of river stage are expected if the river is a local source of recharge to the aquifer.

Conceptually, as a river loses water to an aquifer, the physical and chemical properties of the river may affect those of the ground water. Depending on the occurrence of geochemical processes such as sorption and precipitation, surface water leaking to an aquifer may transport dissolved or possibly particulate constituents to the ground water. Depending on the relative chemistry, this may cause a decrease or increase in constituent concentrations in the ground water. Similarly, water temperature may be a useful tracer of river water recharging the aquifer. Surfacewater temperatures are generally more temporally variable than ground-water temperatures. Therefore, the temperature of ground water affected by local recharge from a river is likely to be more variable than the temperature of ground water of a more regional system. In addition, temporal changes in leakage could influence the distance that river water and its physical and chemical properties are transmitted into the aquifer. During high streamflow and resulting high leakage conditions, the river water may travel farther laterally out into the aquifer than during low streamflow.

\section{Spokane River Streamflow Losses}

The mean annual flow of the Spokane River near Post Falls over the period of record (1913 through $2001)$ is about 6,200 cubic feet per second $\left(\mathrm{ft}^{3} / \mathrm{s}\right)$. Annual mean flow during water year 2001 (October 1, 2000, through September 30, 2001) was about $2,700 \mathrm{ft}^{3} / \mathrm{s}$, or 44 percent of normal. Monthly mean losses for water years 2000 and 2001 based on the differences in streamflow between the gage at Post Falls and two downstream gages at Otis Orchards and Greenacres, Washington, are included in table 4. Calculations based on the streamflow values between the Post Falls and Otis Orchards gages consistently indicated losses, whereas gains were calculated in a few cases using data from the Greenacres gage. Because ground-water levels along the reach of river between the Post Falls and Greenacres gages are below the river, streamflow gains along this reach are not possible. Also, because of the greater confidence in the accuracy of measurements at the Otis Orchards gage relative to the Greenacres gage, there is a greater confidence in the calculated losses for data from the Post Falls and Otis Orchards gages. 
Table 4. Monthly mean streamflow, calculated losses, and water temperature of the Spokane River between Post Falls, Idaho, and Spokane, Washington, water years 2000-01

$\left[\mathrm{ft}^{3} / \mathrm{s}\right.$, cubic feet per second; --, missing data; negative loss indicates a gain]

\begin{tabular}{|c|c|c|c|c|c|c|c|}
\hline \multirow[b]{2}{*}{ Date } & \multicolumn{3}{|c|}{ Monthly mean streamflow ( $\left.\mathrm{ft}^{3} / \mathrm{s}\right)$} & \multicolumn{2}{|c|}{$\begin{array}{l}\text { Calculated monthly mean } \\
\text { streamflow loss }\left(\mathrm{ft}^{3} / \mathrm{s}\right)\end{array}$} & \multirow{2}{*}{$\begin{array}{c}\text { Loss of } \\
\text { streamflow } \\
\text { between } \\
\text { stations } \\
12419000 \text { and } \\
12419500 \\
\text { (percent) }\end{array}$} & \multirow{2}{*}{$\begin{array}{c}\text { Monthly } \\
\text { mean water } \\
\text { temperature } \\
\text { at station } \\
12419000 \\
\text { (degrees } \\
\text { Celsius) }\end{array}$} \\
\hline & $\begin{array}{c}\text { Spokane River } \\
\text { near Post Falls, } \\
\text { Idaho } \\
\text { (station } \\
\text { 12419000) }\end{array}$ & $\begin{array}{l}\text { above Liberty } \\
\text { Bridge near } \\
\text { Otis Orchards, } \\
\text { Washington } \\
\text { (station } \\
\text { 12419500) }\end{array}$ & $\begin{array}{c}\text { Spokane River } \\
\text { at Greenacres, } \\
\text { Washington } \\
\text { (station } \\
\text { 12420500) }\end{array}$ & $\begin{array}{c}\text { Between } \\
\text { stations } \\
12419000 \text { and } \\
12419500\end{array}$ & $\begin{array}{c}\text { Between } \\
\text { stations } \\
12419000 \text { and } \\
12420500\end{array}$ & & \\
\hline $10 / 1999$ & 1,952 & 1,705 & 1,628 & 247 & 324 & 12.7 & -- \\
\hline 11/1999 & 3,042 & 2,765 & 2,616 & 277 & 426 & 9.1 & -- \\
\hline $12 / 1999$ & 7,489 & 6,913 & 6,738 & 576 & 751 & 7.7 & -- \\
\hline $01 / 2000$ & 4,423 & 4,138 & 4,100 & 285 & 323 & 6.4 & -- \\
\hline $02 / 2000$ & 6,602 & 6,171 & 6,068 & 431 & 534 & 6.5 & -- \\
\hline $03 / 2000$ & 10,260 & 9,725 & 9,558 & 535 & 702 & 5.2 & -- \\
\hline $04 / 2000$ & 20,750 & 20,210 & 20,030 & 540 & 720 & 2.6 & -- \\
\hline $05 / 2000$ & 16,920 & 16,110 & 16,150 & 810 & 770 & 4.8 & -- \\
\hline $06 / 2000$ & 7,231 & 6,716 & 6,646 & 515 & 585 & 7.1 & -- \\
\hline $07 / 2000$ & 1,850 & 1,647 & 1,632 & 203 & 218 & 11.0 & -- \\
\hline $08 / 2000$ & 522 & 391 & 432 & 131 & 90 & 25.1 & 23.2 \\
\hline $09 / 2000$ & 1,338 & 1,148 & 1,158 & 190 & 180 & 14.2 & 17.8 \\
\hline $10 / 2000$ & 2,383 & 2,199 & 2,159 & 184 & 224 & 7.7 & 12.7 \\
\hline $11 / 2000$ & 2,147 & 1,978 & 1,994 & 169 & 153 & 7.9 & 7.1 \\
\hline $12 / 2000$ & 1,666 & 1,514 & 1,591 & 152 & 75 & 9.1 & 3.7 \\
\hline $01 / 2001$ & 903 & 834 & 945 & 69 & -42 & 7.6 & 2.8 \\
\hline $02 / 2001$ & 1,116 & 1,010 & 1,118 & 106 & -2 & 9.5 & 2.6 \\
\hline $03 / 2001$ & 2,206 & 2,028 & 2,075 & 178 & 131 & 8.1 & 4.4 \\
\hline $04 / 2001$ & 4,938 & 4,678 & 4,593 & 260 & 345 & 5.3 & 5.9 \\
\hline $05 / 2001$ & 11,190 & 10,850 & 10,830 & 340 & 360 & 3.0 & 11.1 \\
\hline $06 / 2001$ & 3,395 & 3,145 & 3,124 & 250 & 271 & 7.4 & 16.3 \\
\hline $07 / 2001$ & 1,039 & 717 & 780 & 322 & 259 & 31.0 & 22 \\
\hline $08 / 2001$ & 366 & 149 & 150 & 217 & 216 & 59.3 & 22.6 \\
\hline $09 / 2001$ & 800 & 516 & 494 & 284 & 306 & 35.5 & 19.5 \\
\hline Minimum & 366 & 149 & 150 & 69 & -42 & 2.6 & 2.6 \\
\hline Maximum & 20,750 & 20,210 & 20,030 & 810 & 770 & 59.3 & 23.2 \\
\hline Median & 2,295 & 2,114 & 2,117 & 255 & 288 & 7.8 & 11.9 \\
\hline
\end{tabular}

${ }^{1}$ Hourly temperature data were recorded July 31, 2000, through September 30, 2001. 
Daily mean Spokane River streamflow values (water years 2000 and 2001) from the Post Falls and the Otis Orchards gages (Kimbrough and others, 2001, 2002) indicated that daily losses ranged from 10 to $900 \mathrm{ft}^{3} / \mathrm{s}$, with a median of $240 \mathrm{ft}^{3} / \mathrm{s}$, although some daily losses were within the estimated 5-percent range of measurement error. Some daily loss estimates may be affected by the time of travel between Post Falls and Otis Orchards because streamflow changes rapidly on some days due to releases at the dam at Post Falls. Therefore, streamflow losses based on daily values may be underestimated or overestimated during periods of rapidly fluctuating streamflow. Calculating losses using monthly mean streamflow values reduces the effect of traveltime between the two gages.

Monthly mean losses between the Post Falls and Otis Orchards gages during water years 2000 and 2001 ranged from 69 to $810 \mathrm{ft}^{3} / \mathrm{s}$, with a median of $255 \mathrm{ft}^{3} / \mathrm{s}$ (table 4). Estimates of monthly mean streamflow loss over the 6.8-mile reach between the two gages ranged from about 10 to $119 \mathrm{ft}^{3} / \mathrm{s}$ per river mile. Losses determined from this study are somewhat similar to those calculated by Gearhart and Buchanan (2000), who used streambed areas and Darcy's Law for the reach between the Idaho-Washington State line and the Sullivan Road bridge (losses of $104 \mathrm{ft}^{3} / \mathrm{s}$ during low flow conditions to $571 \mathrm{ft}^{3} / \mathrm{s}$ during high flow conditions).

The greatest losses during water years 2000 and 2001 occurred when streamflow was greatest, consistent with increased leakage as a result of increased streambed area and streambed conductance. However, losses during relatively low late-summer flows were greater than during some other parts of the year with similar or greater streamflow (fig. 6). For example, the mean streamflow for July 2001 was $1,039 \mathrm{ft}^{3} / \mathrm{s}$ with a calculated loss of $322 \mathrm{ft}^{3} / \mathrm{s}$ between Post Falls and Otis Orchards. The mean streamflow for February 2001 was higher $\left(1,116 \mathrm{ft}^{3} / \mathrm{s}\right)$, but the calculated loss was lower $\left(106 \mathrm{ft}^{3} / \mathrm{s}\right)$. With the exception of October 1999 , the greatest relative percentage of streamflow loss occurred during the summer months (July, August, and September) with the warmest water temperatures (table 4). The change of water viscosity with

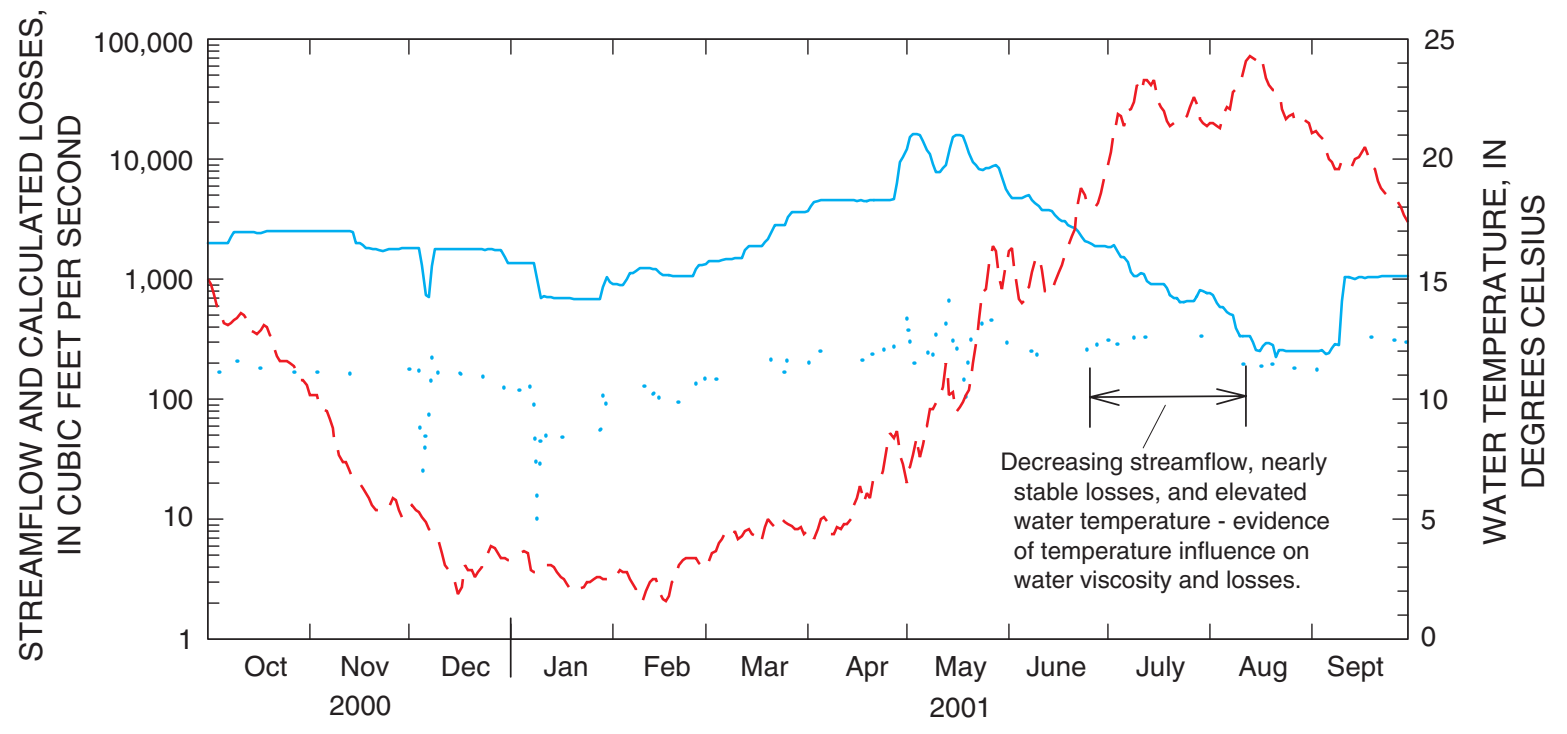

WATER YEAR 2001

EXPLANATION

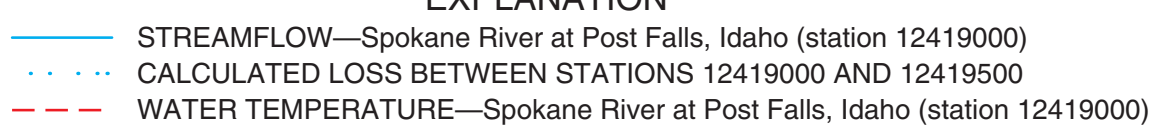

Figure 6. Spokane River streamflow and water temperature at Post Falls, Idaho, and calculated streamflow losses between Post Falls, Idaho (station 12419000), and Otis Orchards, Washington (station 12419500), water year 2001. 
temperature may explain why summer low flows have a relatively high percentage of streamflow loss. The hydraulic conductivity of a porous material (including streambed material) is influenced by water temperature; as water temperature increases, the viscosity of water decreases. Constanz and Murphy (1991) reported that an increase of water temperature from 0 to 25 degrees Celsius $\left({ }^{\circ} \mathrm{C}\right)$ results in a doubling of ponded-infiltration rates through streambeds.

\section{Ground-Water Levels and Flow Directions}

Water levels in monitoring wells and inventoried wells ranged from about 12 feet to more than 200 feet below land surface (Bowers and others, 2003). Water levels in about 70 alluvial wells measured primarily during August and September 2000 were used to construct the water-table map of the area between Post Falls and Spokane (fig. 7). Based on the generalized

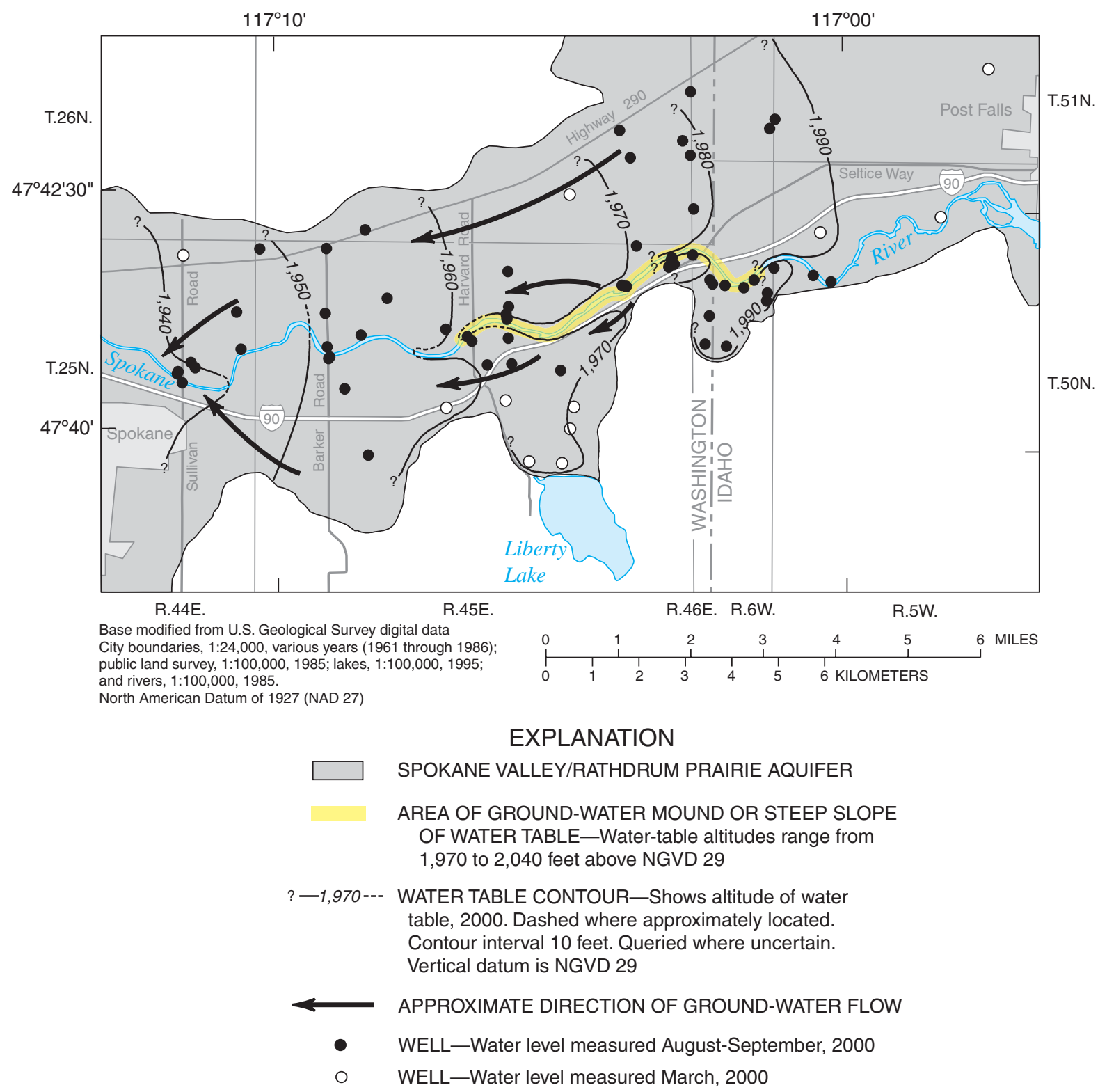

Figure 7. Generalized water table of the Spokane Valley/Rathdrum Prairie aquifer between Post Falls, Idaho, and Spokane, Washington. 
water-table contours (fig. 7), the hydraulic gradient for the regional flow system in the central part of the valley is about 0.001 (5.4 feet per mile), which is consistent with the reported high transmissivity for the aquifer. However, the hydraulic gradient determined using data for the monitoring wells near the losing reach of the river is more than an order of magnitude larger ( 0.08 or 422 feet per mile). This large hydraulic gradient results from localized recharge from the river and possibly less-permeable, near-river aquifer material. A possible cause of the lower permeability in the near-river part of the aquifer (near-river aquifer) is a larger proportion of fine-grained material, which had been transported into the interstitial spaces of the aquifer by leakage from the river.

Figure 8 displays generalized hydrogeologic sections of the SVRP aquifer showing selected monitoring wells. Water levels in nearly all of the wells were below that of the river, and the slope of the water table was away from the river (fig. 8), which indicates that water was flowing from the river into the aquifer. These findings are consistent with a study by Gearhart and Buchanan (2000), who concluded that the river lost streamflow between Post Falls and the Barker Road bridge near Spokane (fig. 3) with unsaturated conditions between the river and aquifer. Downstream near well 25 (fig. 3), Gearhart and Buchanan (2000) determined that the river was transitional as it varied from losing to gaining as the water table and river stage fluctuated.

Because water levels in most wells were tens of feet below the river, previous investigations concluded that unsaturated conditions exist between the river and the water table along most of the upper Spokane River. However, previous studies did not have wells located as close to the river as this study did. Water levels in nearriver wells indicate that saturated conditions may exist below some parts of the losing reach of the Spokane River. Conditions appear saturated below the river in the vicinity of wells 1 and 2, as the water-level altitude in the shallow well (2) is similar to the altitude of the bottom of the river channel (fig. 8a). Saturated conditions also may exist at locations shown in figures $8 \mathrm{~b}$, $8 \mathrm{c}$, and $8 \mathrm{~d}$. The water table would intercept the river at those locations if the water table measured in the nearriver wells were extended towards the river along a similar gradient. Farther downstream (figs. 8e and 8f), the slope of the water table is relatively flat and well below the river, especially for the August 2001 data, and likely indicates unsaturated conditions in that area.
Conditions beneath the river may not only vary from saturated to unsaturated spatially, but also with time and river stage. There is considerable variability in the observed hydraulic gradients in the near-river aquifer indicating that leakage, streambed conductance, and/or aquifer properties may vary along the losing reach of the river. Hydraulic gradients at the more downstream wells (figs. 8e and 8f) were nearly flat (less than 0.01) during low streamflow in August 2001, indicating that less water is leaking from the river within those areas or that the near-river aquifer is more permeable as compared to upstream. However, during May 2001 when streamflow was large and leakage increased, the water table would intercept the river based on the water-table gradient at wells 18 and 19 (fig. 8e). Unsaturated conditions beneath the river still appeared to exist at the downstream wells (fig. 8f) during May 2001.

Downward components of flow are large where water enters the ground as recharge, as would be expected along a losing reach of the Spokane River. Water levels in pairs of shallow and deep near-river wells (wells 1 and 2, 4 and 5, 8 and 9, and 11 and 12) indicate a large downward component of flow in the near-river aquifer. Water-level altitudes were lower in the deep near-river wells and higher in the shallow wells. A downward component of flow is smaller in wells completed at different depths farther from the river, indicating dominant horizontal flow representative of the regional flow system.

Hydrographs for water year 2001 for the monitoring wells are presented in figure 25 in the appendix. Temporal water levels for individual monitoring wells (based on hourly to biweekly measurements) varied from 4.7 to 18.4 feet during water year 2001. The water-level variations primarily represent the response to changes in recharge, pumping, and river stage. Water levels in most of the wells $(3,4,6,7,12,14,15$, $16,17,18,20,21,22,23,24$, and 25) followed the same general trend, whereas water levels in the shallow near-river wells $(1,2,5,8,9,10,11,13$, and 19) often deviated from that trend (fig. 25).

Figure 9 illustrates river stage of the Spokane River at Post Falls, calculated streamflow losses, and water levels in a representative shallow near-river well (11) and a representative regional ground-water system well (14). The river stage is used as a relative measure of streamflow, with higher stages corresponding to greater streamflows. 
A. Wells 1 and 2
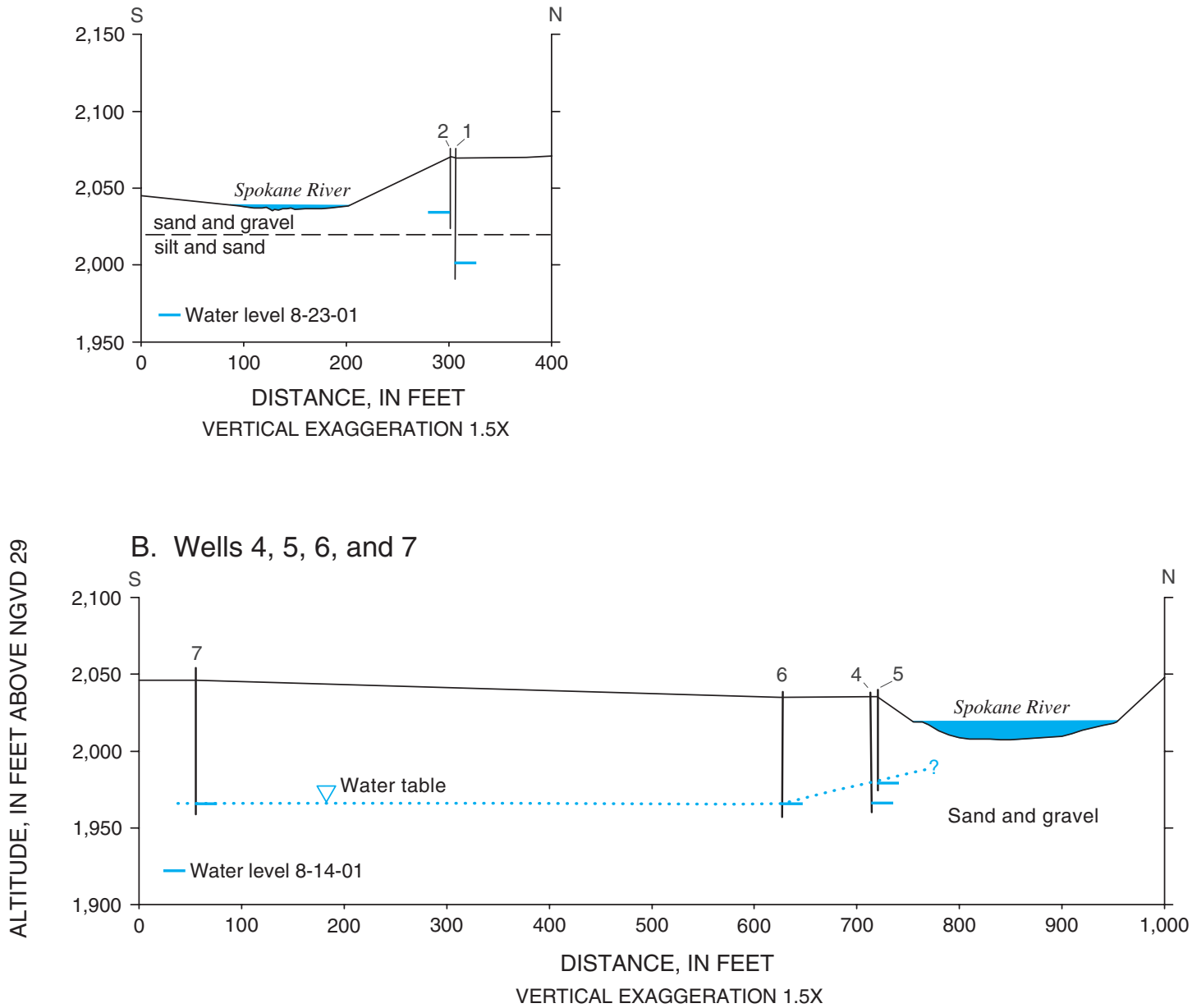

C. Wells 8,9 , and 10

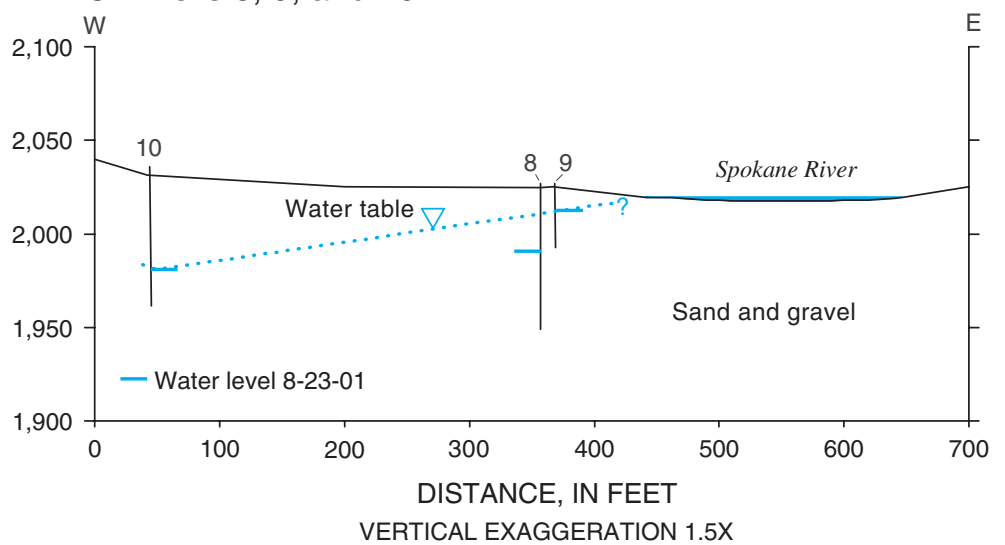

Figure 8. Generalized hydrogeologic sections of the Spokane River channel and Spokane Valley/Rathdrum Prairie aquifer showing selected monitoring wells including water levels and inferred water table. Well locations are shown in figure 3. 

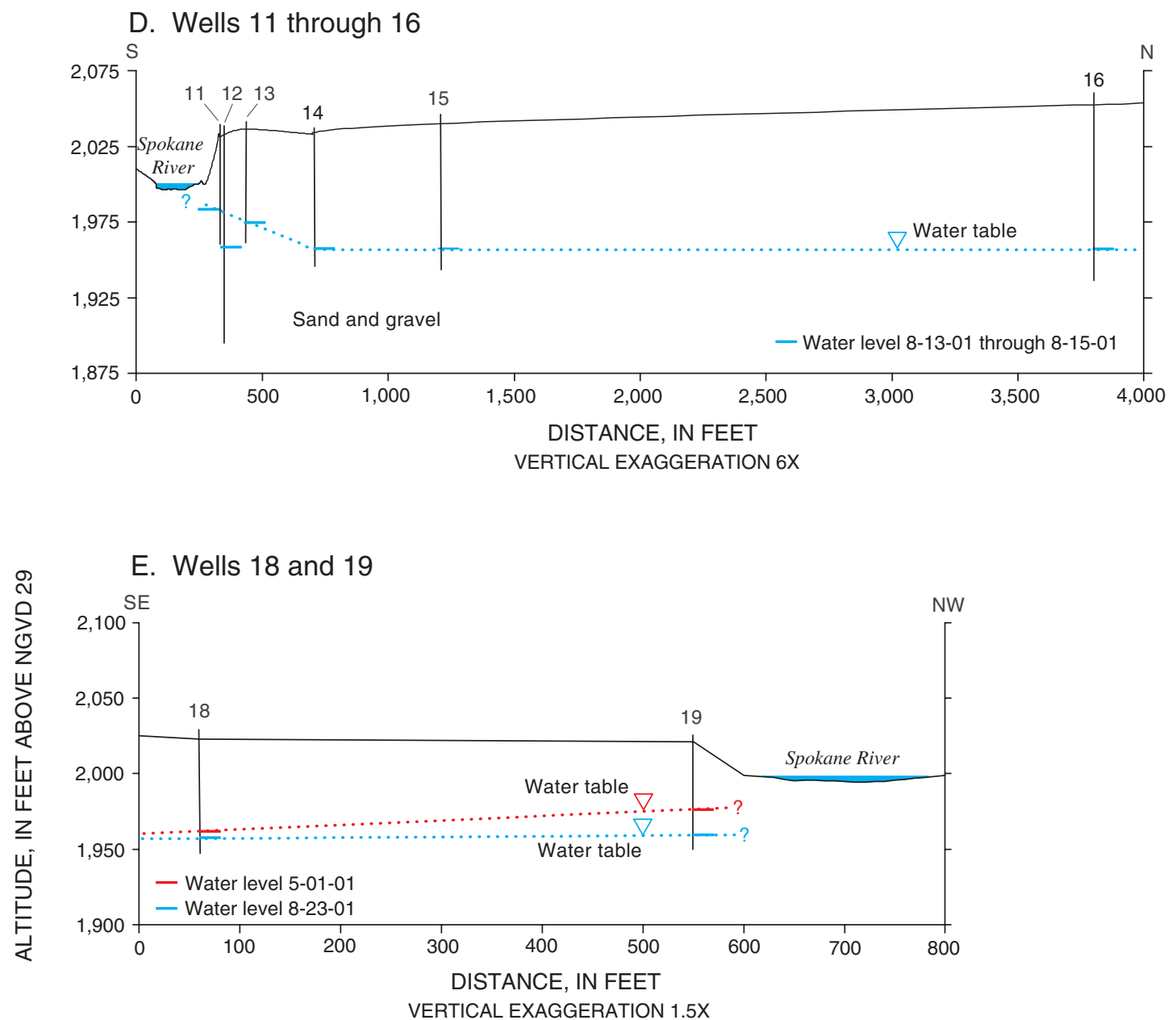

F. Wells 20 through 24

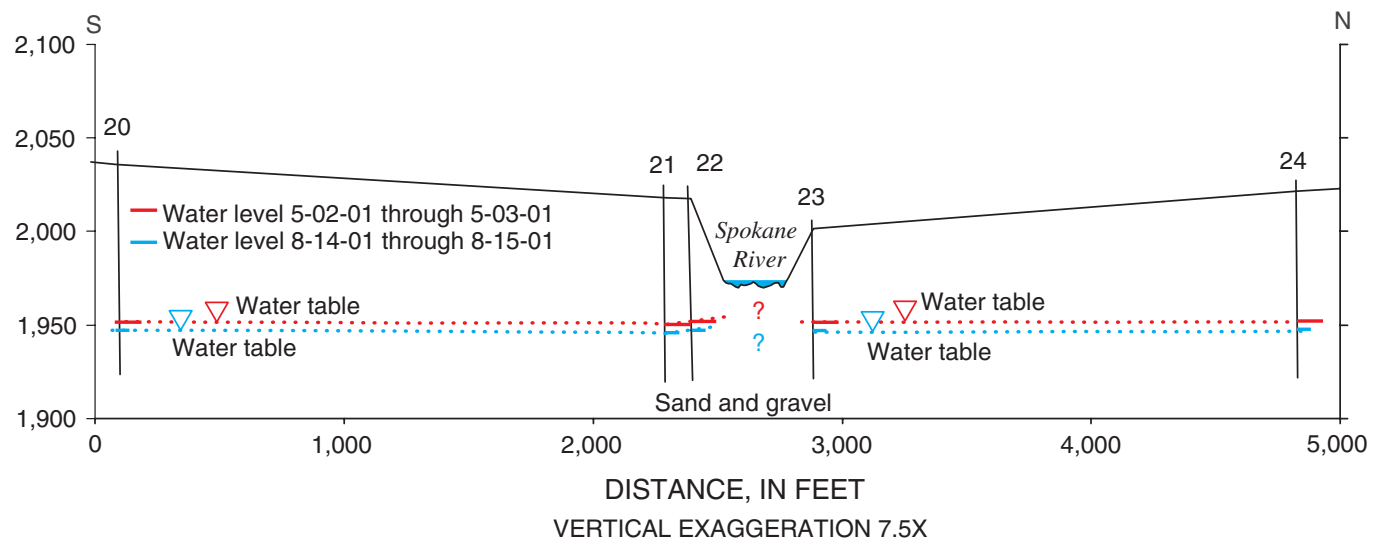

Figure 8. Generalized hydrogeologic sections of the Spokane River channel and Spokane Valley/Rathdrum Prairie aquifer showing selected monitoring wells including water levels and inferred water table. Well locations are shown in figure 3 (Continued). 


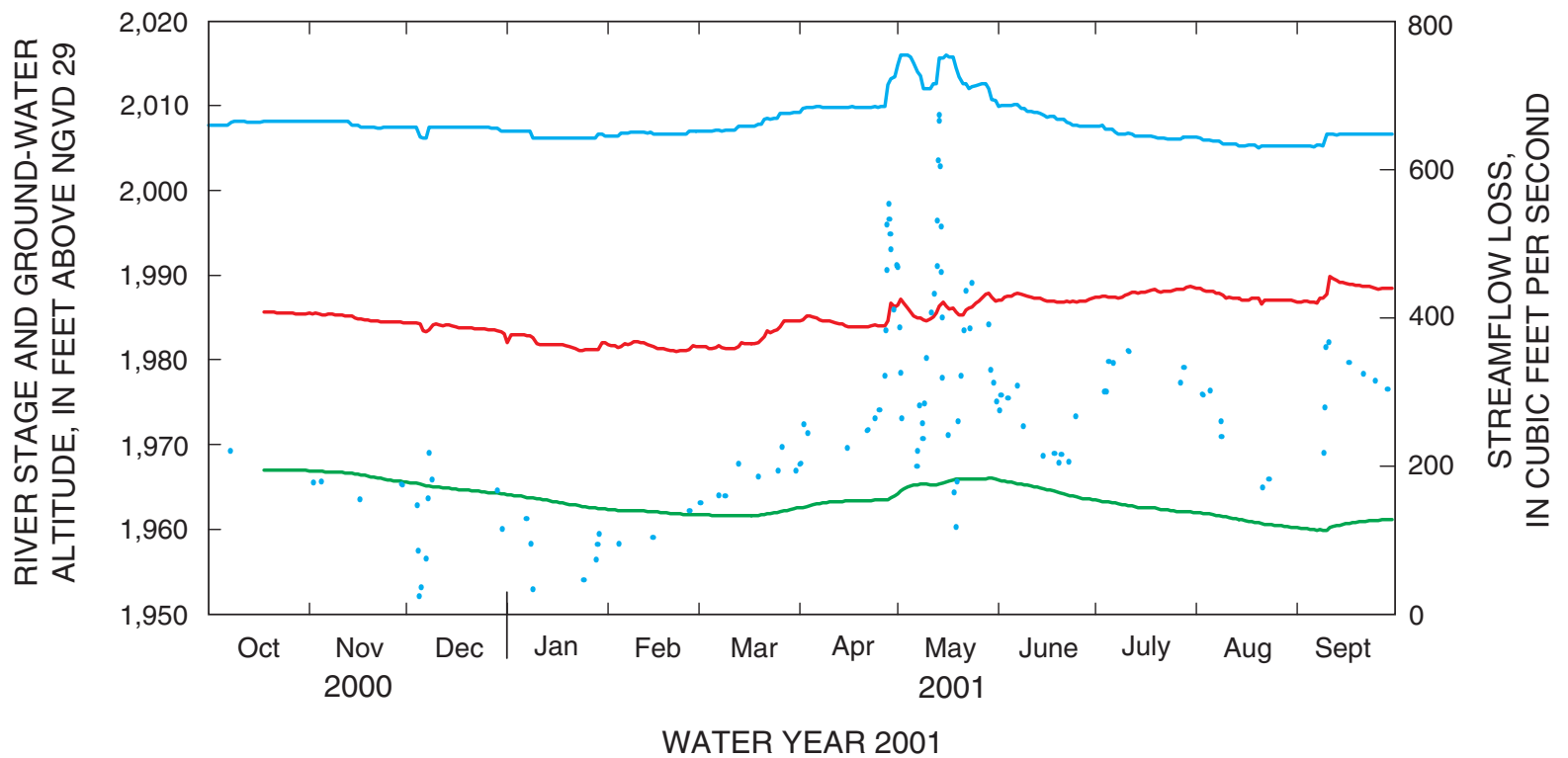

EXPLANATION

RIVER STAGE-Spokane River at Post Falls, Idaho (station 12419000)

WELL 11-100 feet from river (shallow)

WELL $14-475$ feet from river

- - DAILY MEAN STREAMFLOW LOSS-Calculated between Post Falls, Idaho (station 12419000), and Otis Orchards, Washington (station 12419500)

Figure 9. Spokane River stage, water levels in representative wells, and calculated streamflow loss, water year 2001.

Water levels in all wells increased coincident with the high streamflow events in April and May 2001 (example wells 11 and 14, fig. 9). These ground-water level rises are consistent with increased recharge to the aquifer from river leakage, but also may be consistent with increased regional recharge to the aquifer from precipitation and snowmelt during those months. More conclusive evidence of direct river influence on groundwater levels is the rise in water levels in all monitored wells in response to a distinct and abrupt change in river stage as flow was increased at the Post Falls dam during September 2001 (fig. 9). Piper and La Rocque (1944) observed this phenomenon during one of the initial investigations of the aquifer. They noted that groundwater level fluctuations were similar to fluctuations of stage in the river and primarily were a backwater effect of fluctuating river stage. Water moves between a river and a hydraulically connected aquifer depending on the head gradient. As the stage rises to a level higher than the water level in the adjacent hydraulically connected aquifer, water flows from the river to the aquifer and water levels in the near-river aquifer increase. The combination of increased stage (where hydraulically connected) and increased recharge along the losing reach of the river are both contributors to the rise in the water table that is propagated throughout the study area.

Although river stage and streamflow loss are strongly associated, water levels in most near-river wells continued to rise or remain stable coincident with declining river stage during the summer (example well 11, fig. 9). This rise of the near-river water table during the summer apparently resulted from increased recharge from the river due to the decrease in water viscosity as the water temperatures increased. In contrast, the summer water levels in deeper wells and in wells farther from the river appeared to follow the downward trend representative of the regional ground-water system (example well 14, fig. 9). Conceptually, ground water in the shallow near-river aquifer has a steep gradient away from the river or is a mound of the water table underlying the river that exists only because of 
recharge from the river. Therefore, water levels in the near-river aquifer are controlled by hydraulic properties of the aquifer material and the amount of local recharge from the river, in combination with waterlevel fluctuations of the regional system.

Water levels in near-river wells 2, 4, 8, 9, 11, and at times well 19 responded very rapidly to changes in river stage and/or streamflow loss (fig. 25; well 11, fig. 9). The rapid response to changes in stage in the near-river wells is consistent with saturated conditions or a thin unsaturated zone between the river and the underlying aquifer at those locations. The difference in the magnitude of the response to river-stage fluctuations among the near-river wells may result from differing hydraulic properties in the near-river aquifer and streambed material, and the resulting amount of leakage from the river.

Water levels in near-river wells downstream indicate unsaturated or transitional conditions between the river and underlying aquifer. Water levels in well 19 varied from obvious responses to changes in river stage during the spring high-flow conditions to more subtle or delayed responses at other times (fig. 25). The variation in response to river stage and the temporal change in the hydraulic gradient (discussed previously) indicate that conditions may vary from saturated to unsaturated below the river at that location. Ground-water levels obtained during this study and continuous data from Gearhart and Buchanan (2000) showed only small-scale or delayed responses to fluctuations in river stage at the downstream wells (wells 21-23, fig. 8f), indicative of unsaturated conditions or less leakage from the river at that location.

\section{Water Temperature}

Water temperature appears to be a useful tracer of the ground-water recharge from the Spokane River. Measured water temperatures for each of the 25 monitoring wells are included in figure 25 . Temperatures varied about $22^{\circ} \mathrm{C}$ from near 2 to $24^{\circ} \mathrm{C}$ in the river at Post Falls during water year 2001 (fig. 6). Groundwater temperature variations for individual wells ranged from $0.1^{\circ} \mathrm{C}$ (well 16) to $23.4^{\circ} \mathrm{C}$ (well 9) during the year. More stable ground-water temperatures characterized the regional system, whereas water temperatures in near-river wells were more variable, indicative of local recharge.

Temperature ranges observed in the river and wells along a generalized hydrologic section are illustrated in figure 10, and temporal variations are shown in figure 11. The greatest range of temperatures occurred in the Spokane River, and in wells 11 through 14 (fig. 10). Temperatures in wells farther from the river (wells 15 and 16) were relatively constant. The temperature variations in the river and wells 11 through
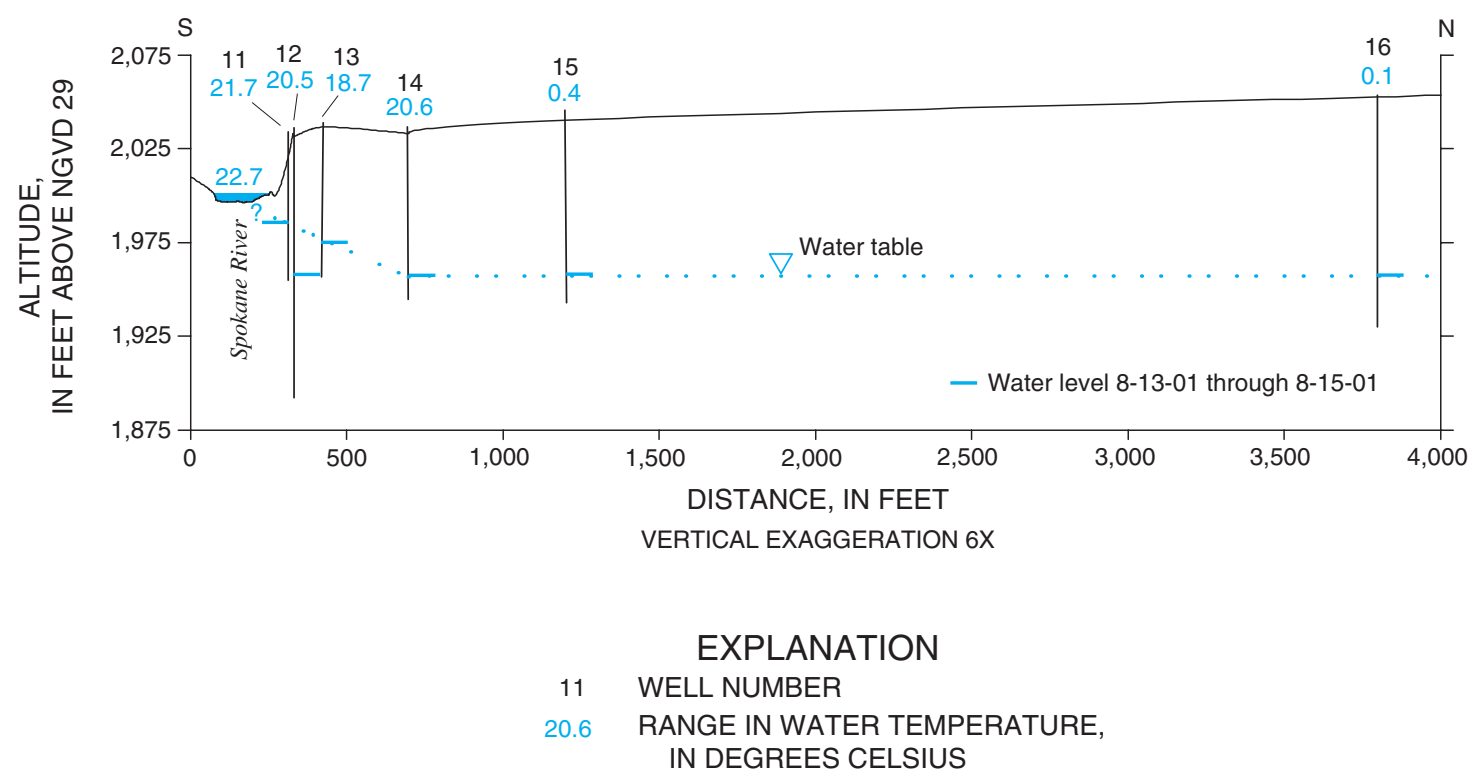

Figure 10. Generalized hydrologic section showing temperature range of the Spokane River measured at Post Falls, Idaho, and ground water from wells 11 through 16, water year 2001. 


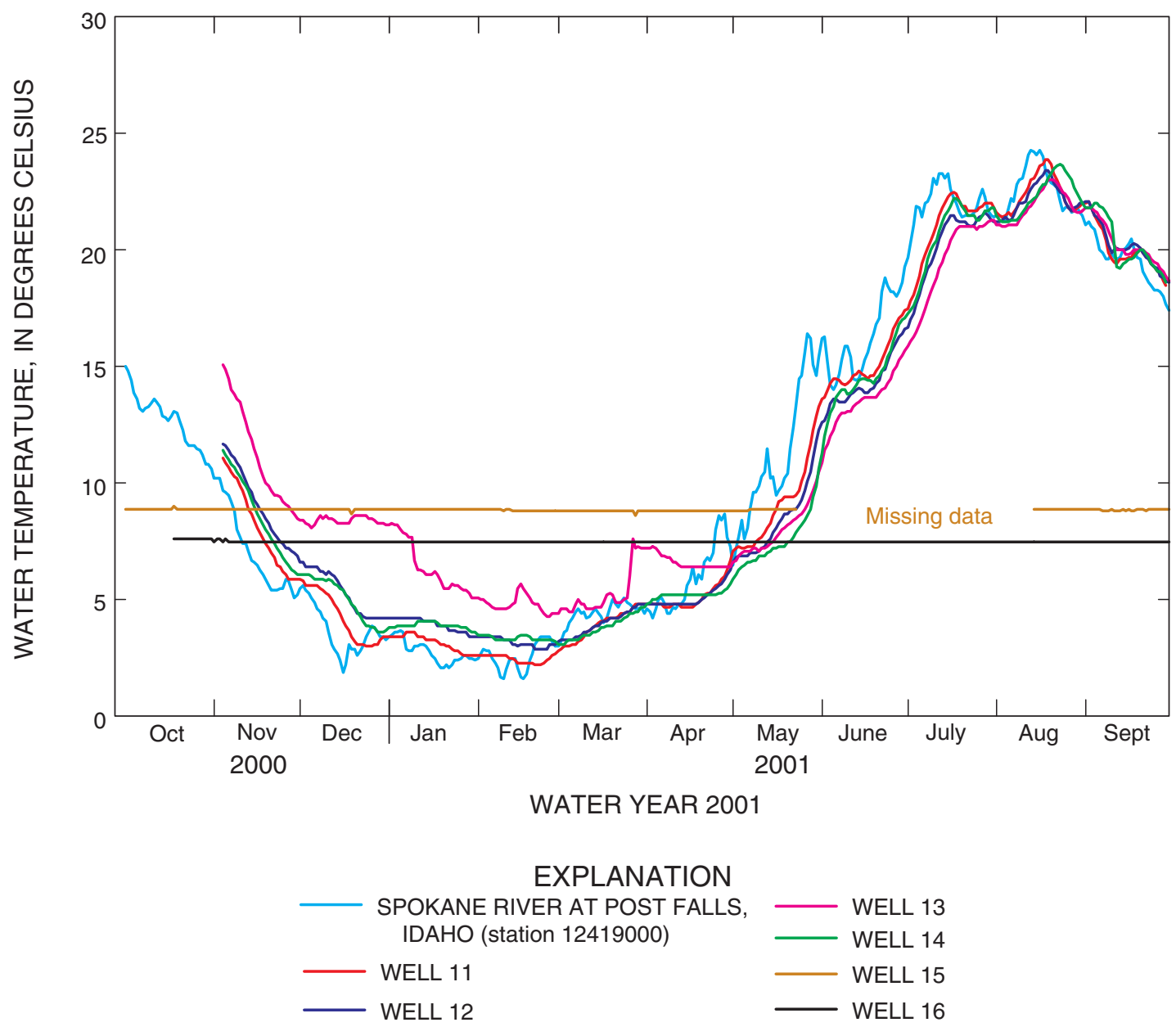

Figure 11. Temperature record of the Spokane River measured at Post Falls, Idaho, and ground water from wells 11 through 16, water year 2001.

14 are similar (fig. 11), indicating that water recharging the aquifer from the river travels quickly. The sharp contrast in temperature variation between well 14 (about 475 feet from the river) and well 15 (about 900 feet from the river) (fig. 11) indicates that recharge water from the river is constrained within a relatively narrow zone (less than 900 feet from the river) at that location.

Water temperature in several wells $(2,4,5,6,8$, $9,10,11,12,13,14$, and 23 ) responded rapidly to temperature changes in the river and also followed the same general temperature variation (fig. 25). The rapid response in these wells indicates that river water is flowing to these wells quickly. Water-temperature variations in wells $1,19,21$, and 22 also appear to be affected by river recharge, but the temperature variations did not coincide with the river temperature, and the magnitude of the temperature variations were not as great (fig. 12). These wells include a component of river recharge, but represent water with longer traveltimes from the river to these wells, the effects of water traveling through an unsaturated zone, possibly a mixture of water of different origins, or some combination of these three processes. Temperatures in other wells $(3,7,15,16,17,18,20,24$, and 25$)$ varied by only a few degrees during the study (fig. 25), indicative of more regional ground water that is unaffected by local river recharge.

\section{Water Chemistry}

The surface water and ground water sampled for this study was of good quality and generally acceptable for most purposes. All constituents analyzed were at 
concentrations less than USEPA drinking-water standards (U.S. Environmental Protection Agency, 2002a). Physical properties and water chemistry data for the Spokane River and ground water sampled as part of this study are included in Bowers and others (2003).

Median concentrations of selected physical properties and major ions of the Spokane River and monitoring wells are listed in table 5. The sampled waters were generally of low ionic concentrations with median dissolved-solids concentrations less than 200 milligrams per liter $(\mathrm{mg} / \mathrm{L})$ at all sites. Median dissolved-solids concentrations were $34 \mathrm{mg} / \mathrm{L}$ in the river at Post Falls and ranged from 37 to $196 \mathrm{mg} / \mathrm{L}$ in the ground-water samples. Field values of $\mathrm{pH}$ ranged from 6.4 to 8.2 (Bowers and others, 2003), with only one sample (well 23, pH of 6.4) outside the acceptable USEPA Secondary Drinking Water Regulation (SDWR) range of 6.5 to 8.5 (U.S. Environmental Protection Agency, 2002a).

\section{Specific Conductance}

Specific-conductance data (an indication of dissolved solids) from this study and others (Bolke and
Vaccaro, 1979; Parliman and others, 1980; Stone and others, 1996) shows that ground water adjacent to the losing reach of the Spokane River has a lower ionic strength than regional ground water (fig. 13). The river had the lowest measured specific conductance values (median of 50 microsiemens per centimeter). The lower specific conductance in near-river wells is further evidence of river water recharging the aquifer.

\section{Major Ions}

In samples from the Spokane River and the 25 monitoring wells, bicarbonate generally had the highest concentrations of the major ions, followed by calcium, sulfate, sodium, magnesium, chloride, and potassium (table 5). Fluoride and bromide concentrations were less than $0.2 \mathrm{mg} / \mathrm{L}$ in all samples (Bowers and others, 2003). The relative proportions of major ions in ground water and the Spokane River generally were similar (fig. 14) —all calcium magnesium bicarbonate type waters. River source, transitional, and regional ground water shown in figure 14 are defined in the following discussion of dissolved solids.

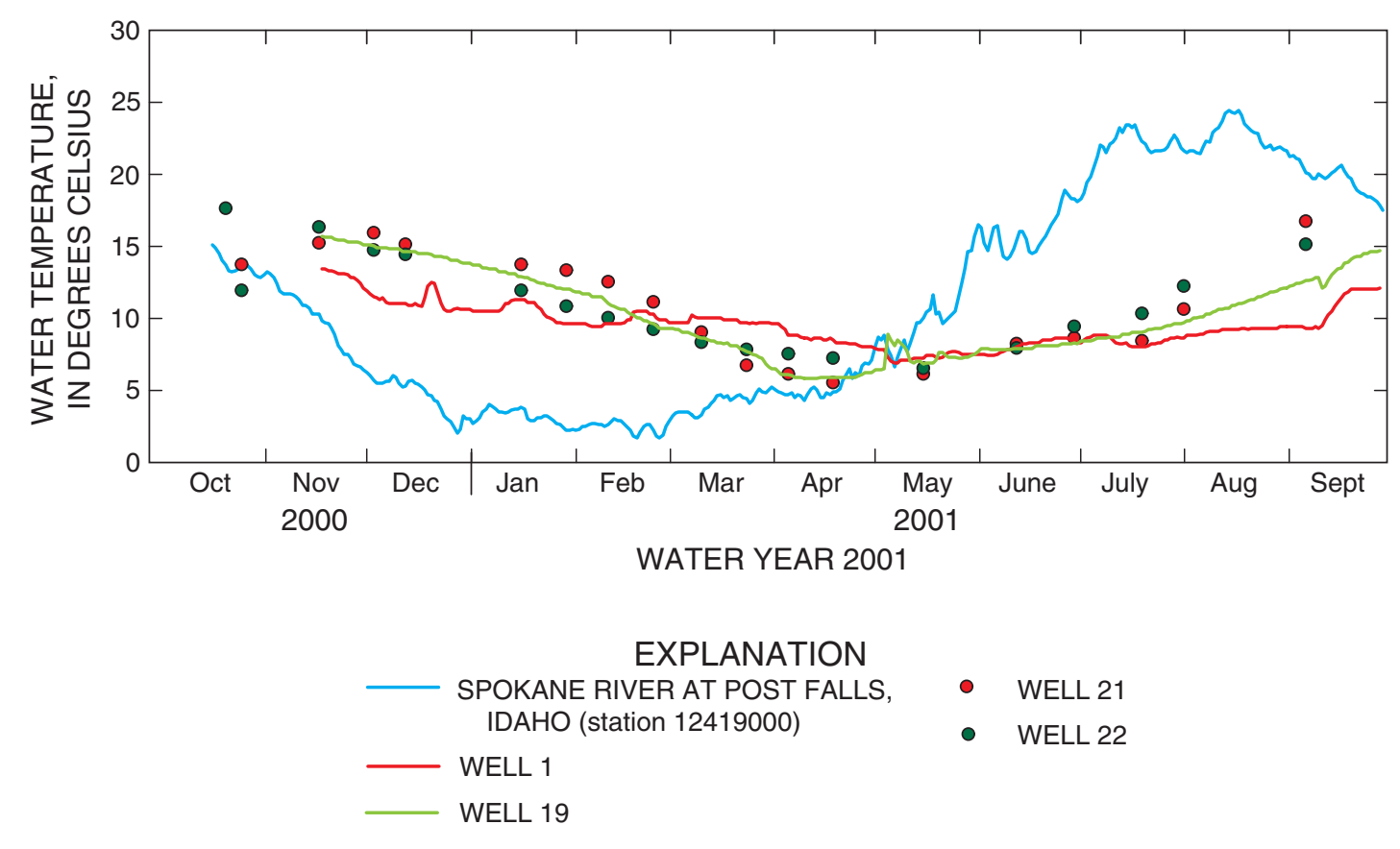

Figure 12. Temperature record of the Spokane River measured at Post Falls, Idaho, and ground water from wells $1,19,21$, and 22, water year 2001 . 
Table 5. Median specific conductance, $\mathrm{pH}$, and major-ion concentrations of the Spokane River and ground water from monitoring wells within the Spokane Valley/Rathdrum Prairie aquifer, 1999-2001

[ $\mu \mathrm{S} / \mathrm{cm}$, microsiemens per centimeter at 25 degrees Celsius; $\mathrm{mg} / \mathrm{L}$ milligrams per liter]

\begin{tabular}{|c|c|c|c|c|c|c|c|c|c|c|c|}
\hline $\begin{array}{l}\text { Site } 1 / \text { well } \\
\text { number }^{2}\end{array}$ & $\begin{array}{c}\text { Number } \\
\text { of } \\
\text { samples } \\
\text { collected }\end{array}$ & $\begin{array}{c}\text { Specific } \\
\text { conduct- } \\
\text { ance, } \\
\text { field } \\
(\mu \mathrm{S} / \mathrm{cm})\end{array}$ & $\begin{array}{l}\text { pH, } \\
\text { field } \\
\text { (stan- } \\
\text { dard } \\
\text { units) }\end{array}$ & $\begin{array}{c}\text { Calcium, } \\
\text { dissolved } \\
\text { (mg/L as } \\
\text { Ca) }\end{array}$ & $\begin{array}{l}\text { Magne- } \\
\text { sium, } \\
\text { dissolved } \\
\text { (mg/L as } \\
\mathrm{Mg})\end{array}$ & $\begin{array}{c}\text { Sodium, } \\
\text { dissolved } \\
\text { (mg/L as } \\
\mathrm{Na})\end{array}$ & $\begin{array}{l}\text { Potas- } \\
\text { sium, } \\
\text { dissolved } \\
\text { (mg/L as } \\
\text { K) }\end{array}$ & $\begin{array}{c}\text { Bicar- } \\
\text { bonate, } \\
\text { dissolved } \\
(\mathrm{mg} / \mathrm{L} \text { as } \\
\left.\mathrm{HCO}_{3}\right)\end{array}$ & $\begin{array}{c}\text { Sulfate, } \\
\text { dissolved } \\
(\mathrm{mg} / \mathrm{L} \text { as } \\
\left.\mathrm{SO}_{4}\right)\end{array}$ & $\begin{array}{c}\text { Chloride, } \\
\text { dissolved } \\
(\mathrm{mg} / \mathrm{L} \text { as } \\
\text { Cl) }\end{array}$ & $\begin{array}{c}\text { Dis- } \\
\text { solved } \\
\text { solids, } \\
\text { calcu- } \\
\text { lated } \\
(\mathrm{mg} / \mathrm{L})\end{array}$ \\
\hline Spokane River & 28 & 50 & 7.4 & 5.4 & 1.6 & 1.7 & 0.71 & 22 & 4.2 & 0.90 & 34 \\
\hline 1 & 7 & 74 & 6.7 & 9.2 & 2.5 & 2.5 & .82 & 39 & 5.0 & 1.3 & 54 \\
\hline 2 & 8 & 54 & 7.1 & 5.8 & 1.8 & 1.8 & .66 & 24 & 5.0 & .92 & 38 \\
\hline 3 & 5 & 284 & 8.0 & 32 & 15 & 2.9 & 2.2 & 156 & 12 & 2.4 & 156 \\
\hline 4 & 8 & 52 & 7.0 & 5.8 & 1.7 & 1.9 & .78 & 26 & 4.6 & 1.0 & 38 \\
\hline 5 & 7 & 54 & 6.8 & 5.8 & 1.7 & 2.0 & .77 & 26 & 4.8 & .98 & 38 \\
\hline 6 & 7 & 54 & 6.9 & 5.8 & 1.7 & 1.9 & .76 & 26 & 4.7 & .93 & 37 \\
\hline 7 & 7 & 87 & 7.2 & 11 & 2.8 & 2.0 & .95 & 46 & 4.9 & 1.2 & 57 \\
\hline 8 & 9 & 54 & 7.0 & 5.7 & 1.7 & 1.8 & .73 & 26 & 4.8 & .98 & 37 \\
\hline 9 & 8 & 54 & 7.0 & 5.8 & 1.7 & 1.8 & .72 & 26 & 4.8 & 1.1 & 38 \\
\hline 10 & 7 & 54 & 7.0 & 5.7 & 1.7 & 1.8 & .74 & 26 & 4.8 & 1.0 & 37 \\
\hline 11 & 7 & 52 & 7.0 & 5.7 & 1.7 & 1.8 & .69 & 24 & 4.5 & 1.0 & 38 \\
\hline 12 & 6 & 52 & 7.0 & 6.0 & 1.8 & 1.9 & .70 & 26 & 4.8 & 1.0 & 38 \\
\hline 13 & 7 & 53 & 7.0 & 6.1 & 1.8 & 1.9 & .65 & 26 & 4.9 & 1.1 & 38 \\
\hline 14 & 6 & 56 & 7.2 & 6.6 & 1.8 & 2.0 & .68 & 28 & 4.9 & 1.0 & 40 \\
\hline 15 & 7 & 307 & 7.8 & 35 & 17 & 2.8 & 2.2 & 181 & 15 & 1.8 & 174 \\
\hline 16 & 6 & 323 & 7.7 & 37 & 18 & 3.0 & 2.0 & 191 & 16 & 1.6 & 182 \\
\hline 17 & 7 & 91 & 7.8 & 12 & 2.7 & 1.8 & .94 & 49 & 4.5 & 1.0 & 57 \\
\hline 18 & 7 & 58 & 7.0 & 7.2 & 1.8 & 1.8 & .81 & 30 & 4.2 & 1.1 & 42 \\
\hline 19 & 7 & 53 & 6.9 & 5.9 & 1.6 & 1.9 & .79 & 26 & 4.6 & .88 & 39 \\
\hline 20 & 6 & 134 & 7.4 & 16 & 5.4 & 2.2 & 1.2 & 71 & 6.5 & 1.6 & 80 \\
\hline 21 & 6 & 52 & 6.8 & 6.0 & 1.6 & 1.8 & .69 & 26 & 5.0 & 1.0 & 38 \\
\hline 22 & 6 & 53 & 6.8 & 5.8 & 1.7 & 1.8 & .74 & 26 & 4.7 & 1.0 & 38 \\
\hline 23 & 6 & 58 & 6.8 & 6.4 & 1.8 & 1.9 & .74 & 26 & 4.9 & 1.3 & 40 \\
\hline 24 & 6 & 346 & 7.7 & 42 & 18 & 3.1 & 2.1 & 208 & 16 & 1.4 & 196 \\
\hline 25 & 6 & 259 & 7.9 & 30 & 13 & 2.8 & 1.7 & 150 & 12 & 1.7 & 147 \\
\hline
\end{tabular}

${ }^{1}$ Spokane River sampled at Post Falls, Idaho (station 12419000).

${ }^{2}$ Number corresponds to wells listed in table 1 and shown in figure 3. 

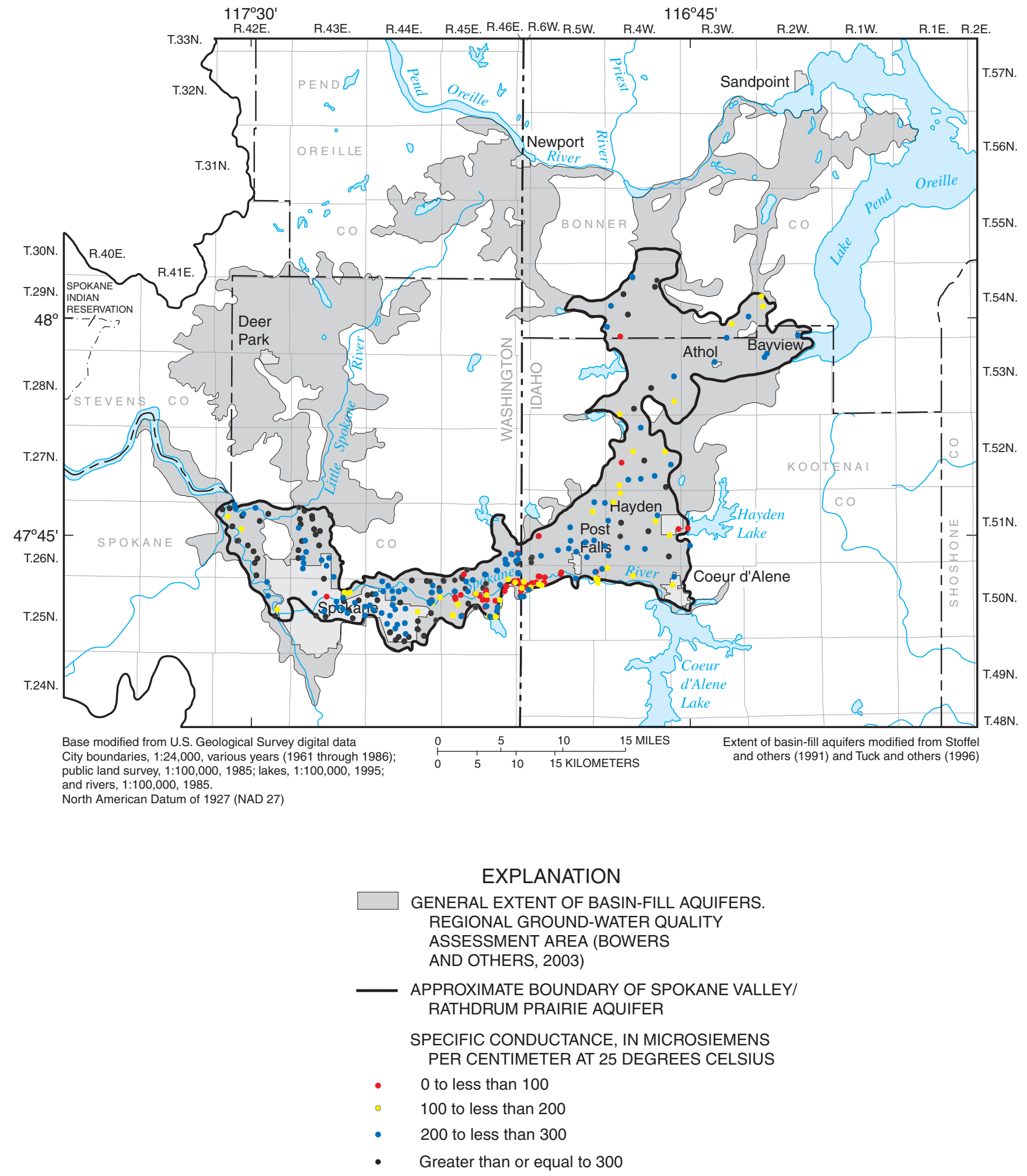

Figure 13. Specific conductance of ground-water samples from the Spokane Valley/Rathdrum Prairie aquifer, Idaho and Washington. 


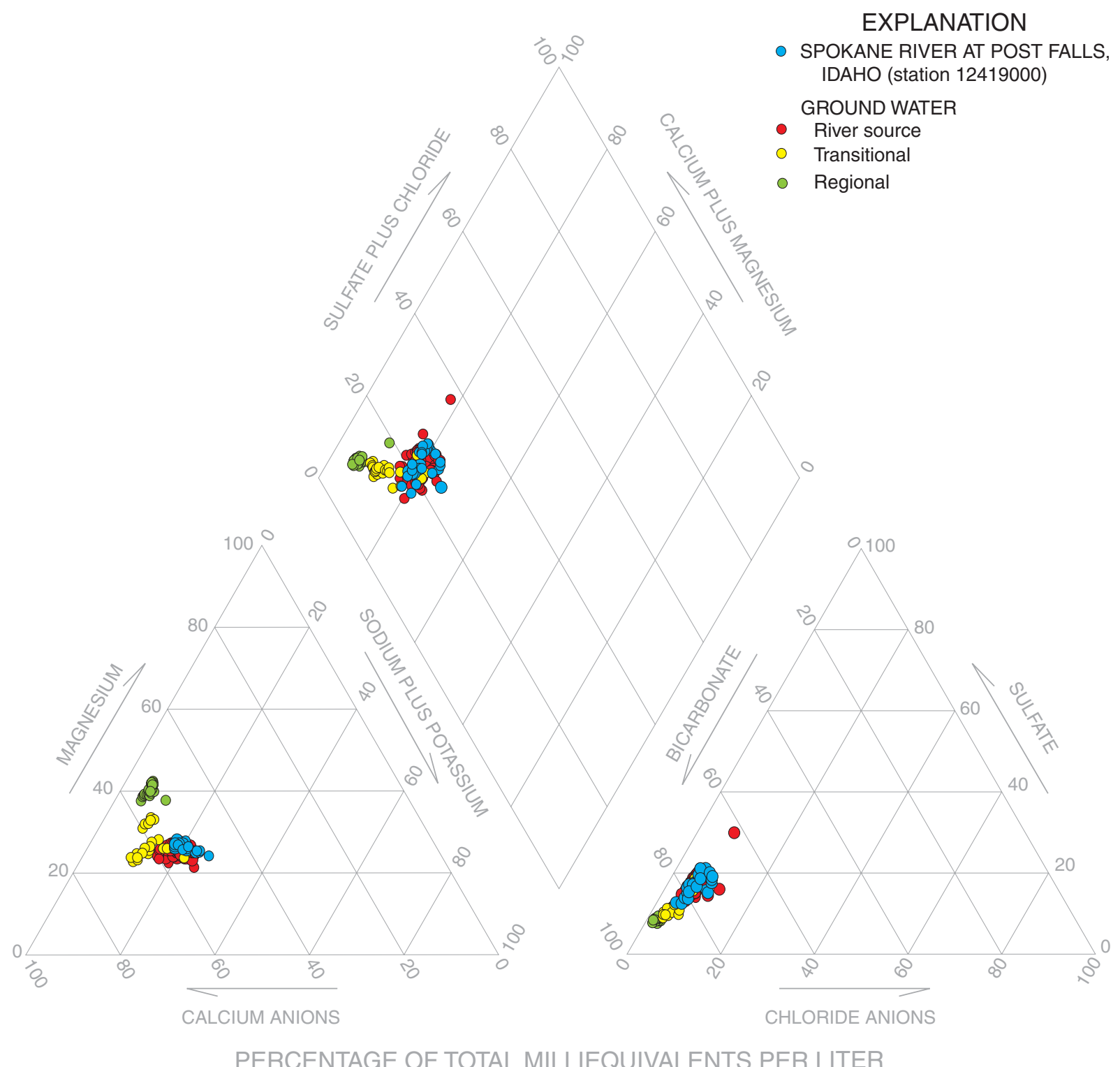

Figure 14. Trilinear diagram showing major-ion composition of the Spokane River at Post Falls, Idaho, and ground water from 25 monitoring wells from the Spokane Valley/Rathdrum Prairie aquifer between Post Falls, Idaho, and Spokane, Washington.

Dissolved-solids concentrations varied with location, with the river having the lowest concentrations and ground water farthest away from the river or in the area where ground water discharges to the river having the highest concentrations (fig. 15). The similarity in major-ion concentrations between samples from the river and several of the near-river monitoring wells indicates that river water with low major-ion concentrations recharges the aquifer along the upper reaches of the Spokane River from Post Falls to near Spokane.
Ground-water wells were categorized into three groups (figs. 14 and 15) based on median dissolvedsolids concentrations: (1) river-source wells, in areas where ground water primarily originated from the Spokane River; (2) regional wells, in areas where ground water did not include water recently recharged from the river; and (3) transitional wells, in areas where ground water was possibly a composite of recharge from the river and water from the regional system. The river-source wells had water with median dissolvedsolids concentrations similar to those of the river (less 
than $50 \mathrm{mg} / \mathrm{L}$ ), were within 650 feet of the river, and had water-level data indicative of local flow (recharge) from the river. The regional wells had water with dissolved-solids concentrations of greater than $100 \mathrm{mg} / \mathrm{L}$, ranged from 100 feet (well 25, which is located in an area of ground-water discharge to the river) to 3,500 feet from the river, and were in areas with relatively flat hydraulic gradients. The transitional wells had water with moderate dissolved-solids concentrations between 50 and $100 \mathrm{mg} / \mathrm{L}$, ranged from 500 to 2,600 feet from the river, and possibly represented a mixture of the river-source and regional ground water. Although the relative proportions of major ions in the river and ground-water samples generally were similar, ground water categorized as transitional or regional generally had slightly greater relative proportions of calcium, magnesium, and bicarbonate than the river and river-source ground water (fig. 14). Dissolved-solids concentrations of all the samples collected from the river and the three well categories are illustrated in the boxplots in figure 16.

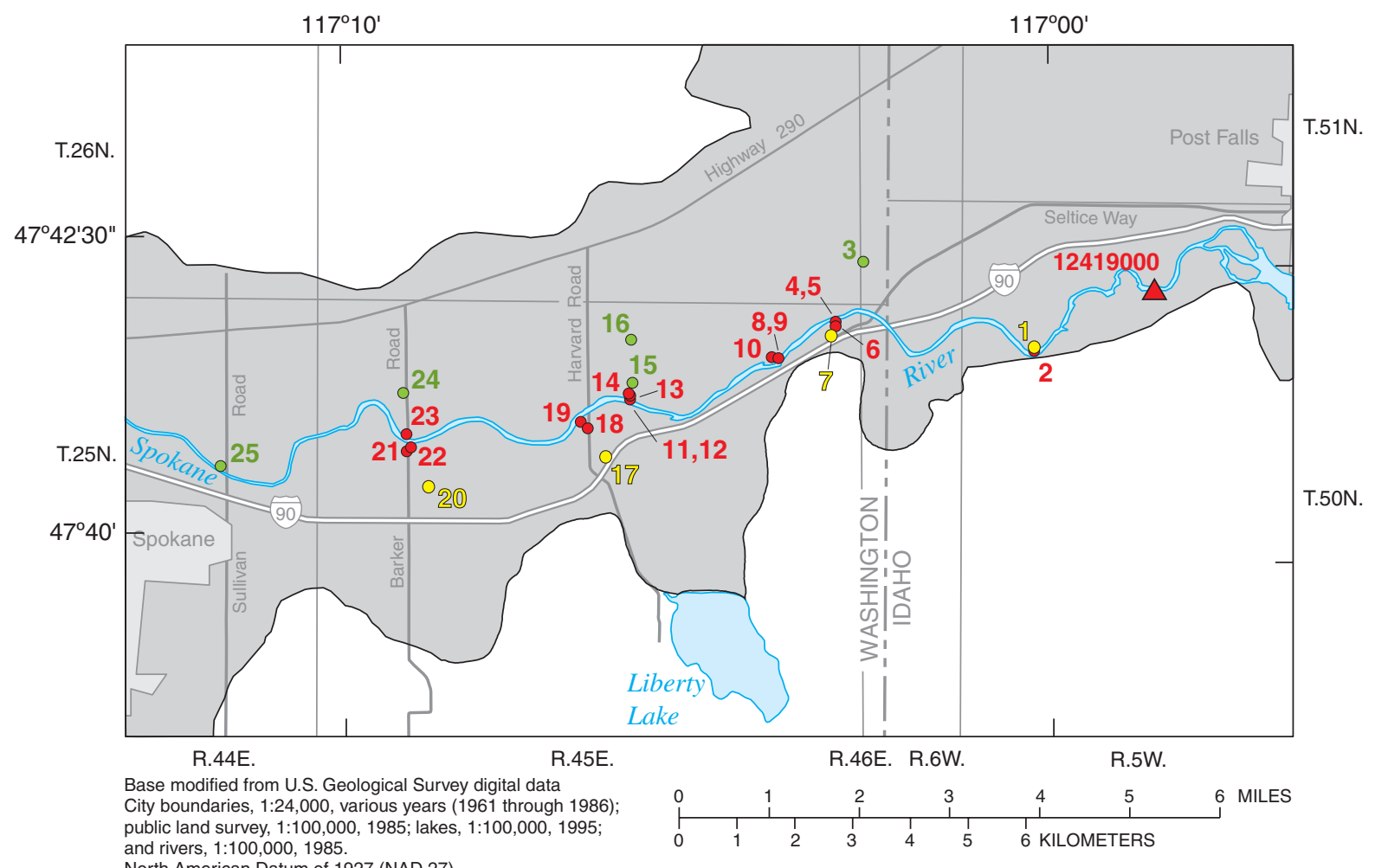

North American Datum of 1927 (NAD 27)

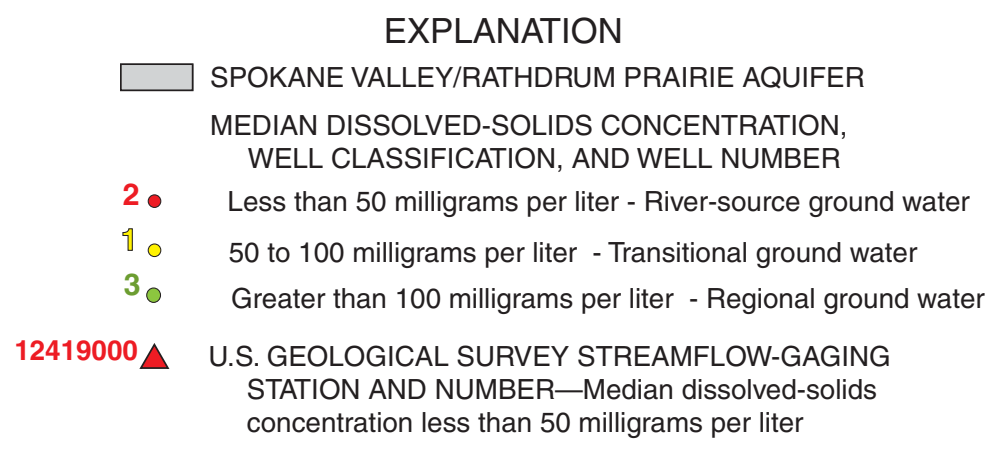

Figure 15. Median dissolved-solids concentrations of samples collected from the Spokane River at Post Falls, Idaho, and ground water classified as river-source, transitional, or regional ground water in the Spokane Valley/Rathdrum Prairie aquifer, Idaho and Washington, 1999-2001. 


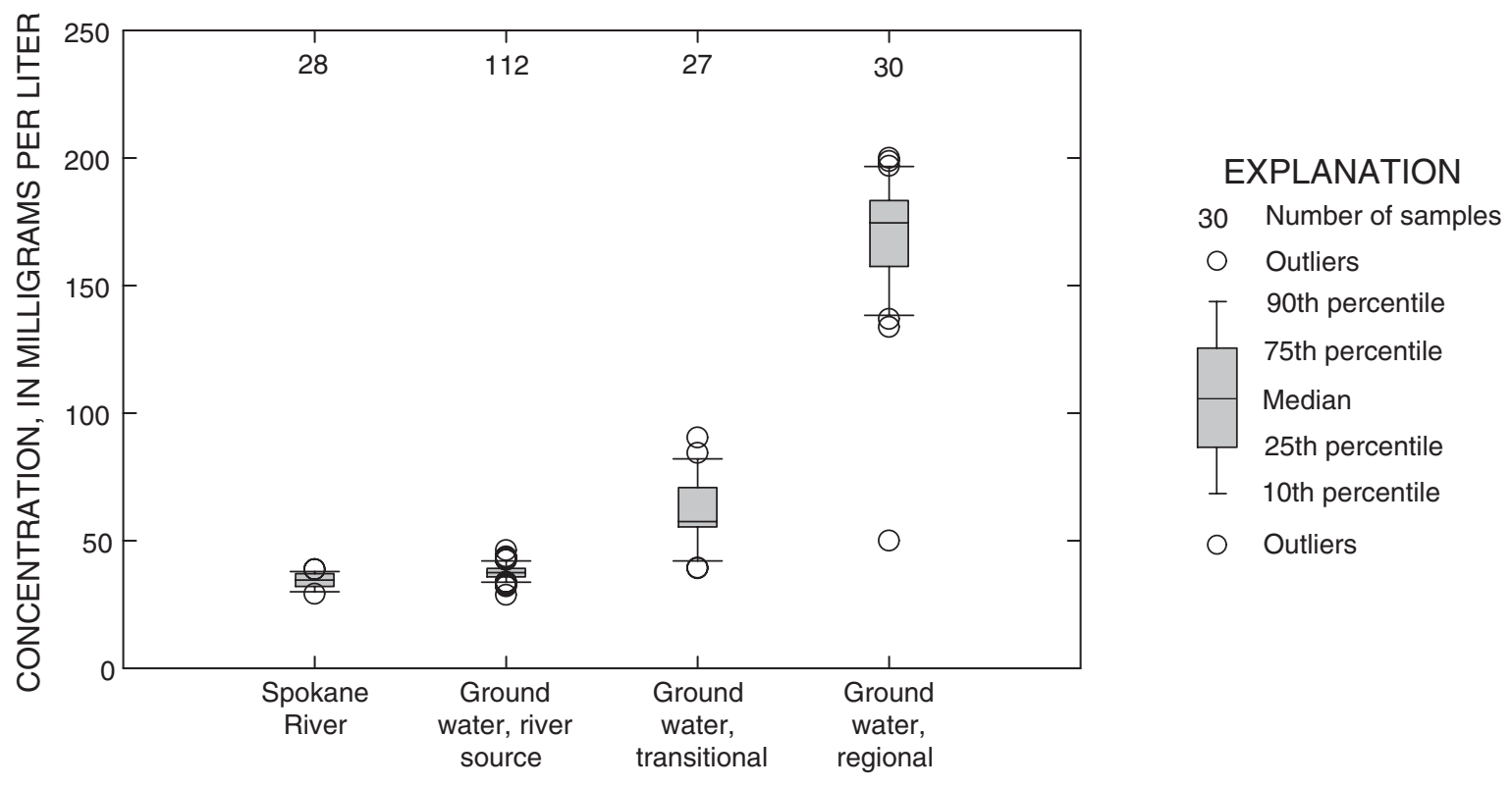

Figure 16. Boxplots summarizing dissolved-solids concentrations of samples collected from the Spokane River at Post Falls, Idaho (station 12419000, water years 1999 through 2001), and ground water identified as river source, transitional, or regional (June 2000 through August 2001) from the Spokane Valley/Rathdrum Prairie aquifer between Post Falls, Idaho, and Spokane, Washington.

\section{Trace Elements}

A summary of trace-element concentrations for the Spokane River and ground-water samples and drinking-water standards are listed in table 6. All concentrations in surface-water and ground-water samples were less than USEPA drinking-water standards (table 6). However, trace-element concentrations in river samples did exceed freshwater aquatic-life criteria (U.S. Environmental Protection Agency, 2002b). Beckwith (2003) reported that zinc concentrations exceeded aquatic-life criteria in 22 of the 26 samples collected at Post Falls. Other metals in the river, including cadmium, copper, and lead, exceeded aquatic-life criteria for the reported hardness levels (Bowers and others, 2003). Dissolved $(0.45-\mu \mathrm{m}$ filtration) and total-recoverable concentrations of trace elements of particular interest (arsenic, cadmium, lead, and zinc) in the river and ground water are listed in table 8 in the appendix.

Based on 1999 and 2000 data, Clark (2003) calculated that 4,600 pounds per year ( $\mathrm{lb} / \mathrm{yr})$ cadmium, 44,000 lb/yr lead, and 980,000 lb/yr zinc was discharged from Coeur d'Alene Lake and was transported to the Spokane River (at Post Falls, Idaho). Clark (2003) estimated losses of $900 \mathrm{lb} / \mathrm{yr}$ of cadmium and $80,000 \mathrm{lb} / \mathrm{yr}$ of zinc from the Spokane River in the reach between Post Falls and about 39 miles downstream at 7-mile Bridge near Spokane (fig. 2). It was speculated that river leakage to the aquifer may account for most of the decreased loads along that reach of the Spokane River.

Boxplots of trace-element concentrations for water year 2001 data (a period of consistently low analytical reporting levels) indicate that the Spokane River is a likely source of cadmium, copper, zinc, and possibly lead in the near-river aquifer (fig. 17). Zinc had the highest concentrations (up to $71 \mu \mathrm{g} / \mathrm{L}$ in ground water) compared to the other trace elements (figs. 17 and 18). Median dissolved concentrations of cadmium, copper, and zinc were the highest in the river and in the near-river wells adjacent to the losing reach of the river. Median dissolved lead concentrations were highest in the river with sporadic occurrences higher than reporting levels in the river-source and transitional ground water (fig. 17), which could be related to a river source. 
Table 6. Summary of selected trace element data collected from the Spokane River and ground water from monitoring wells within the Spokane Valley/Rathdrum Prairie aquifer, 1999-2001

[Due to changing analytical reporting levels, some maximum values are less than the median values. The Maximum Contaminant Level (MCL) is a regulated level that Class A public water-supply systems generally must meet. The Lifetime Health advisory (LHA) is a nonenforceable guideline for non-carcinogens determined based on a 70-kilogram adult consuming 2 liters of water per day over a 70-year lifetime. The Action Levels (ALs) for lead and copper are regulated according to Treatment Types, which may be considered analogous to an MCL for these elements. The Criteria Maximum Concentration $(\mathrm{CMC})$ is an estimate of the highest concentration of a material in surface water to which an aquatic community can be exposed briefly without resulting in an unacceptable effect. The Criterion Continuous Concentration (CCC) is an estimate of the highest concentration of a material in surface water to which an aquatic community can be exposed indefinitely without resulting in an unacceptable effect. $\mu \mathrm{g} / \mathrm{L}$, micrograms per liter; e, estimated; <, less than; --, no data]

\begin{tabular}{|c|c|c|c|c|c|c|c|c|c|}
\hline \multirow[b]{2}{*}{$\begin{array}{c}\text { Trace } \\
\text { elements }\end{array}$} & \multicolumn{4}{|c|}{ Spokane River at Post Falls, Idaho (station 12419000) } & \multicolumn{2}{|c|}{ Ground water } & \multirow[b]{2}{*}{$\begin{array}{c}\text { Drinking-water } \\
\text { standard }^{1} \\
(\mu \mathrm{g} / \mathrm{L})\end{array}$} & \multicolumn{2}{|c|}{ Freshwater aquatic-life criteria $^{2}$} \\
\hline & $\begin{array}{c}\text { Median } \\
\text { dissolved } \\
(\mu \mathrm{g} / \mathrm{L})\end{array}$ & $\begin{array}{c}\text { Maximum } \\
\text { dissolved } \\
(\mu \mathrm{g} / \mathrm{L})\end{array}$ & $\begin{array}{l}\text { Median total } \\
\text { recoverable } \\
(\mu \mathrm{g} / \mathrm{L})\end{array}$ & $\begin{array}{c}\text { Maximum total } \\
\text { recoverable } \\
(\mu \mathrm{g} / \mathrm{L})\end{array}$ & $\begin{array}{c}\text { Median } \\
\text { dissolved } \\
(\mu \mathrm{g} / \mathrm{L})\end{array}$ & $\begin{array}{c}\text { Maximum } \\
\text { dissolved } \\
(\mu \mathrm{g} / \mathrm{L})\end{array}$ & & $\begin{array}{c}\text { CMC } \\
(\mu \mathrm{g} / \mathrm{L})\end{array}$ & $\begin{array}{c}\text { CCC } \\
(\mu \mathrm{g} / \mathrm{L})\end{array}$ \\
\hline Antimony & $<1.0$ & $<1.0$ & $<1.0$ & $<1.0$ & 0.35 & 0.94 & 6 (MCL) & -- & -- \\
\hline Arsenic & $<.90$ & 0.59 & $<2.6$ & 1.6 & .35 & 4.6 & 10 (MCL) & 340 & 150 \\
\hline Barium & 11 & 14 & 12 & 14 & 14 & 32 & 2,000 (MCL) & -- & -- \\
\hline Beryllium & $<1.0$ & $<1.0$ & $<5.0$ & $<5.0$ & $<.06$ & .04 & 4 (MCL) & -- & -- \\
\hline Boron & $<12$ & $\mathrm{e} 8.2$ & -- & -- & 5.8 & 25 & ${ }^{3} 600$ (LHA) & -- & -- \\
\hline Cadmium & $<1.0$ & .22 & .21 & .44 & $<.04$ & .68 & 5 (MCL) & ${ }^{4} .42$ & ${ }^{4} .08$ \\
\hline Chromium & $<.80$ & e. 40 & $<1.0$ & e. 58 & .54 & 11 & 100 (MCL) & ${ }^{5} 150$ & $5_{20}$ \\
\hline Copper & $<1.0$ & 1.5 & $<12$ & e14 & .56 & 7.4 & $1,300(\mathrm{AL})$ & ${ }^{4} 3.0$ & ${ }^{4} 2.3$ \\
\hline Lead & $<1.0$ & 1.6 & 1.0 & 7.8 & $<.08$ & 1.6 & $15(\mathrm{AL})$ & ${ }^{4} 11$ & ${ }^{4} .42$ \\
\hline Mercury & -- & -- & $<.30$ & $<.30$ & -- & -- & 2 (MCL) & 1.4 & .77 \\
\hline Molybdenum & $<1.0$ & $<1.0$ & $<1.0$ & 1.8 & .11 & 2.0 & 40 (LHA) & -- & -- \\
\hline Nickel & $<1.0$ & $<1.0$ & $<1.8$ & $<1.8$ & .35 & 9.8 & 100 (LHA) & ${ }^{4} 120$ & ${ }^{4} 13$ \\
\hline Selenium & $<.70$ & $\mathrm{e} 1.5$ & $<2.6$ & $<2.6$ & $<.33$ & e .43 & 50 (MCL) & -- & 5.0 \\
\hline Strontium & 17 & 21 & 16 & 21 & 20 & 137 & 4,000 (LHA) & -- & -- \\
\hline Thallium & $<.90$ & $<.90$ & -- & -- & $<0.04$ & .18 & 2 (MCL) & -- & -- \\
\hline Uranium & $<1.0$ & $<1.0$ & -- & -- & $<0.02$ & 3.9 & 30 (MCL) & -- & -- \\
\hline Zinc & 54 & 90 & 63 & 96 & 12 & 71 & 2,000 (LHA) & ${ }^{4} 30$ & ${ }^{4} 30$ \\
\hline $\begin{array}{l}{ }^{1} \text { U.S. Environm } \\
{ }^{2} \text { U.S. Environm } \\
{ }^{3} \text { Under review. } \\
{ }^{4} \text { Value based on } \\
{ }^{5} \text { Chromium III c }\end{array}$ & $\begin{array}{l}\text { ection Age } \\
\text { ection Age } \\
\text { ardness (2 }\end{array}$ & $\begin{array}{l}\text { 02a) drinkin } \\
\text { 02b) Nationa } \\
\text { as } \mathrm{CaCO}_{3} \text { ) o }\end{array}$ & $\begin{array}{l}\text { or health ad } \\
\text { mmended W } \\
\text { ookane River }\end{array}$ & $\begin{array}{l}\text { uality Criteria: } 20 \\
\text { t Falls, Idaho (B }\end{array}$ & ind oth & as dissol & centrations. & & \\
\hline
\end{tabular}



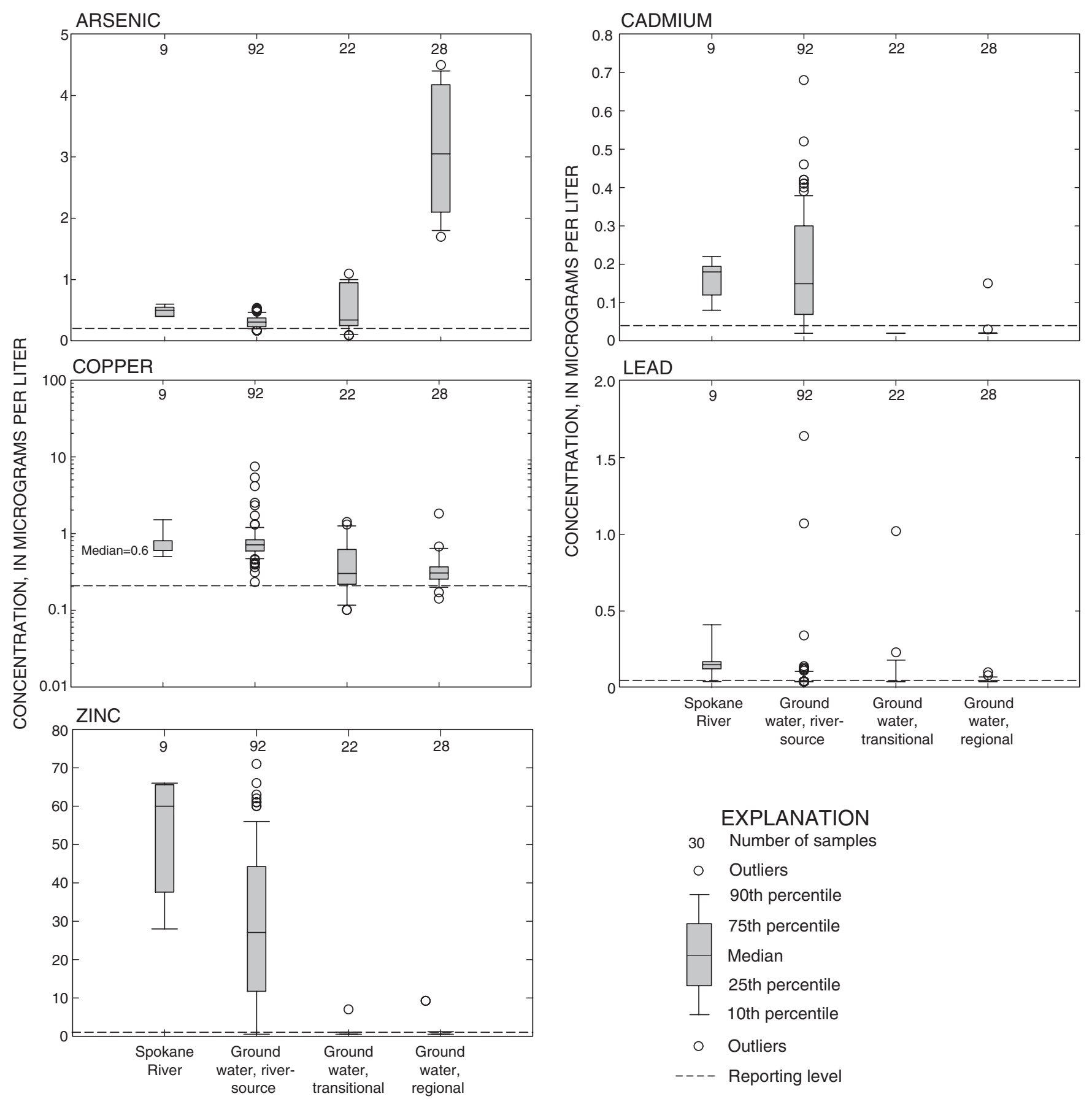

Note: Values less than reporting levels are plotted as one-half the reporting levels

Figure 17. Boxplots summarizing dissolved concentrations of selected trace elements in samples collected from the Spokane River at Post Falls, Idaho (station 12419000), and ground water identified as river source, transitional, or regional from the Spokane Valley/ Rathdrum Prairie aquifer between Post Falls, Idaho, and Spokane, Washington, water year 2001. 


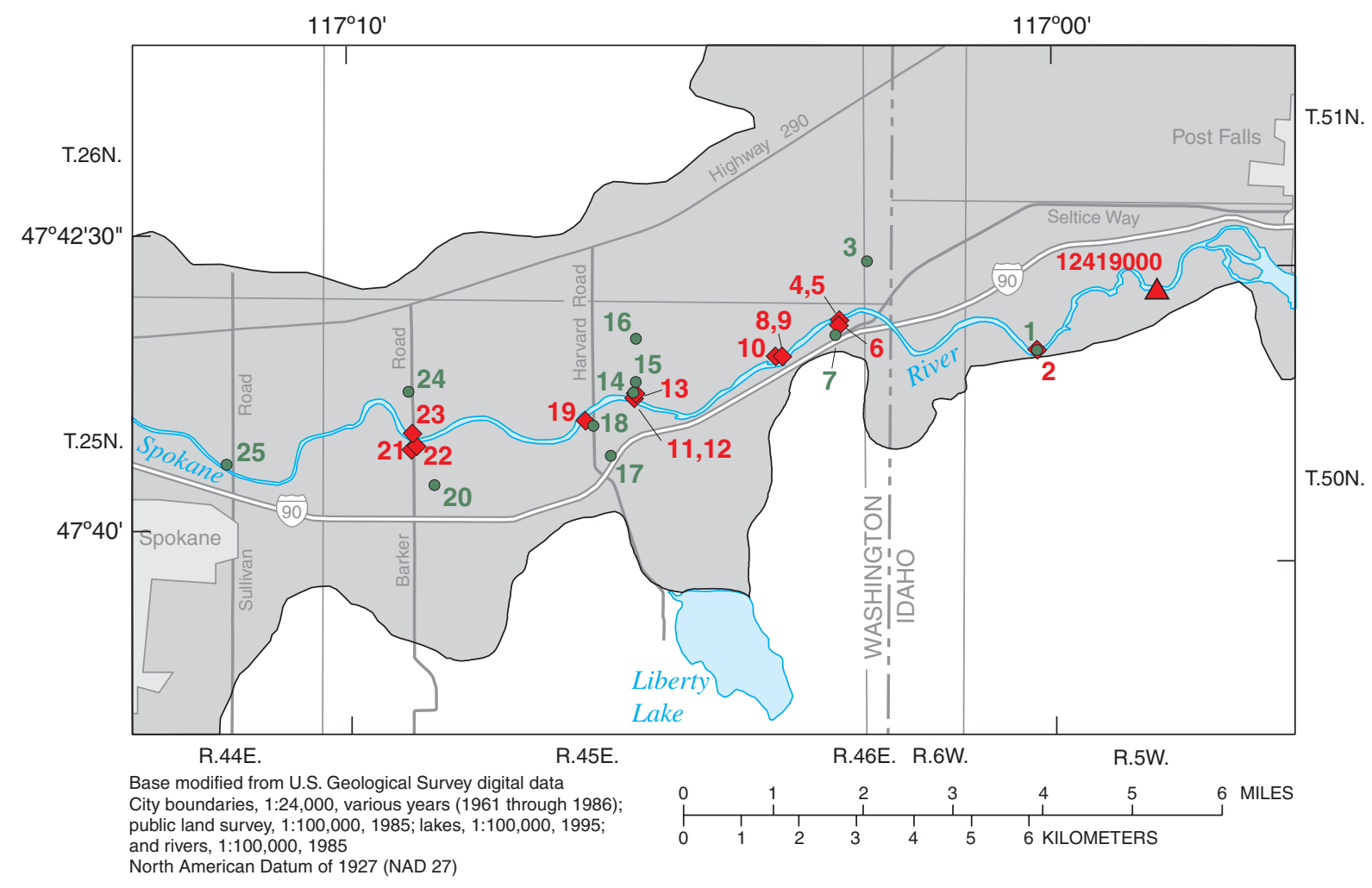

EXPLANATION

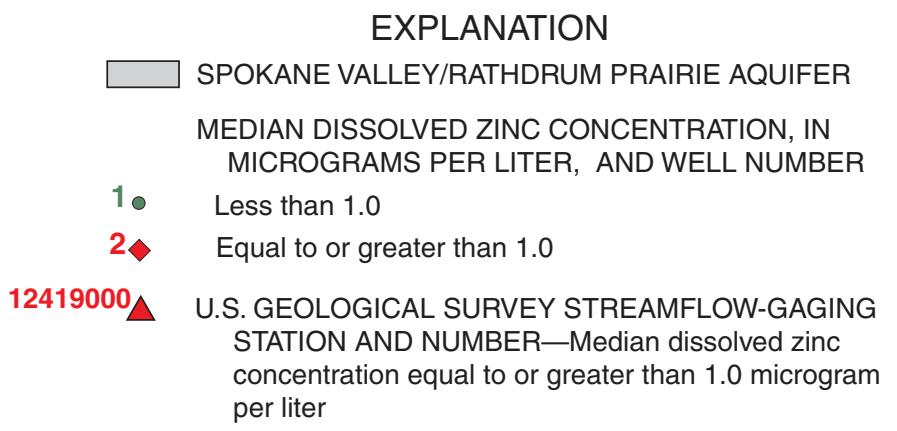

Figure 18. Median dissolved zinc concentrations of samples collected from the Spokane River at Post Falls, Idaho, and ground water from the Spokane Valley/Rathdrum Prairie aquifer between Post Falls, Idaho, and Spokane, Washington, water year 2001.

Arsenic in ground water does not appear to have originated from the Spokane River and probably is derived through the natural interaction of water with rocks and soils. Arsenic concentrations were consistently highest in regional wells (up to $4.5 \mu \mathrm{g} / \mathrm{L}$ ) with concentrations in the river and the river-influenced wells all less than $1.0 \mu \mathrm{g} / \mathrm{L}$ (figs. 17 and 19). Data collected during a regional ground-water assessment as part of the NROK NAWQA in 1999 corroborate these findings (Bowers and others, 2003). Water samples from three wells along the losing reach of the river had arsenic concentrations of less than $1.0 \mu \mathrm{g} / \mathrm{L}$. Water samples from three wells in the aquifer from the regional study exceeded the USEPA Maximum Contaminant Level of $10 \mu \mathrm{g} / \mathrm{L}$ (Bowers and others, 2003). The river also does not appear to be a significant source of lithium, molybdenum, strontium, and uranium because concentrations of these trace elements were elevated in the regional ground water as compared to the river or the river-source wells (Bowers and others, 2003).

Although the trace-element concentrations are relatively low in the surface and ground water, concentrations in streambed sediment collected in the Spokane River are elevated (Beckwith, 2002). Elements of particular environmental concern include arsenic, 


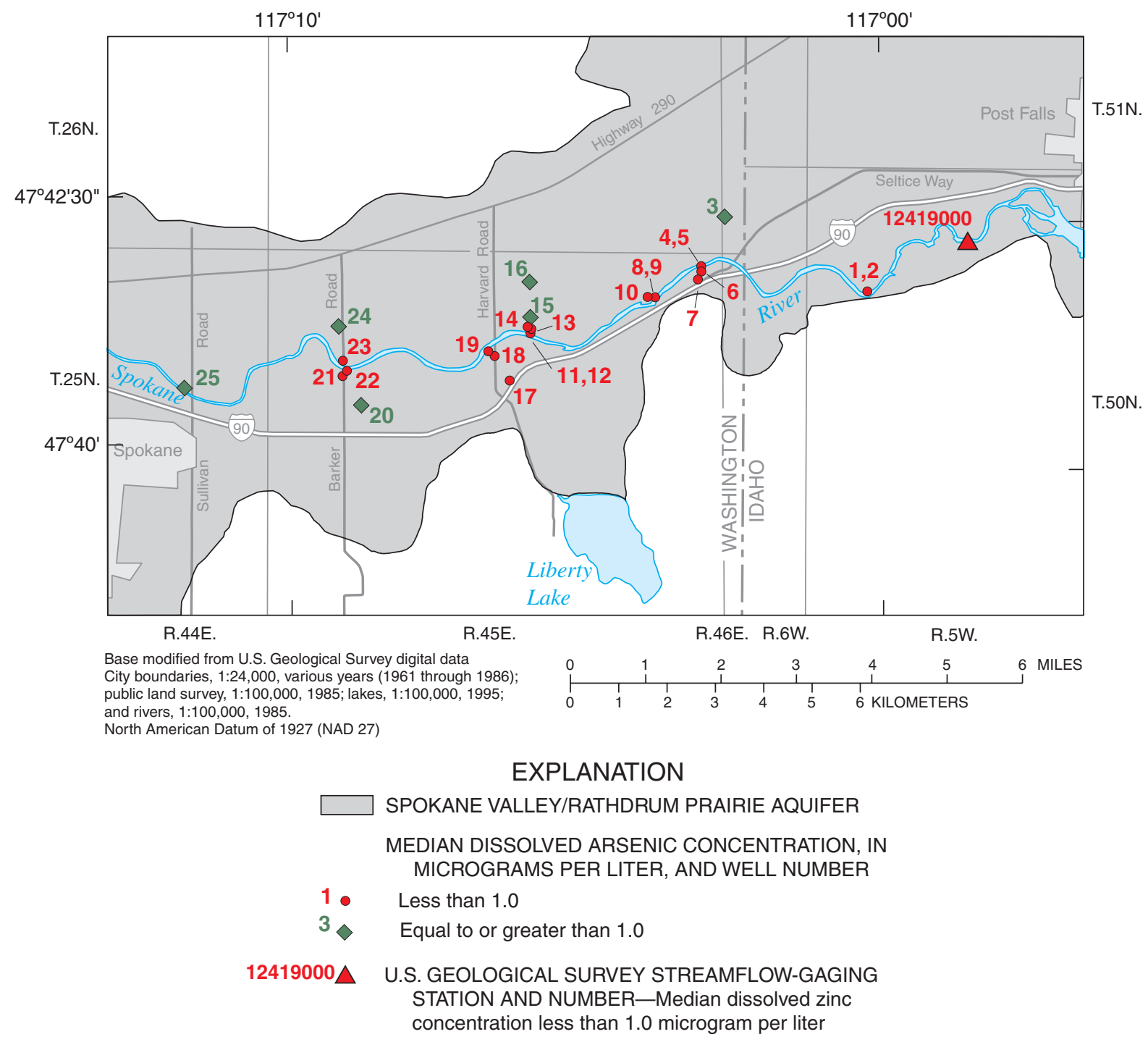

Figure 19. Median dissolved arsenic concentrations of samples collected from the Spokane River at Post Falls, Idaho, and ground water from the Spokane Valley/Rathdrum Prairie aquifer between Post Falls, Idaho, and Spokane, Washington, water year 2001.

cadmium, chromium, copper, lead, mercury, nickel, selenium, and zinc because of toxicity to aquatic and terrestrial biota. Concentrations of these trace elements (excluding selenium) in the bed sediment from the river at Post Falls exceeded the national median value of samples collected between 1992 and 1996 as part of the NAWQA Program (Beckwith, 2002). Of particular interest were high concentrations of lead (1,620 micrograms per gram $(\mu \mathrm{g} / \mathrm{g}))$ and zinc $(3,210 \mu \mathrm{g} / \mathrm{g})$. Because the bed sediment has elevated concentrations of trace elements, the potential exists for transport of dissolved and particulate trace elements from the river to the aquifer.
Particulate transport of trace elements in ground water was examined by collecting total-recoverable (whole-water, unfiltered) samples and filtered $(0.45 \mu \mathrm{m})$ samples from selected wells. Total-recoverable zinc concentrations were consistently equal to or greater than the filtered concentrations in all samples with measurable (greater than the reporting limit) zinc concentrations (table 7). Measurable cadmium concentrations were low (less than $1.0 \mu \mathrm{g} / \mathrm{L}$ ), and the totalrecoverable concentrations were equal to or greater than filtered concentrations, with only one exception (table 7). Total-recoverable lead was detected in five samples from the shallow, near-river wells $(2,5,8$, and 11) at concentrations ranging from 1.3 to $4.2 \mu \mathrm{g} / \mathrm{L}$ and 
with associated dissolved lead concentrations of less than $0.08 \mu \mathrm{g} / \mathrm{L}$ (table 7). Lead may be transported at times in the ground water in the particulate phase. The data indicate that zinc and cadmium are transported primarily in the dissolved (less than $0.45 \mu \mathrm{m}$ ) phase, but a component may be transported in the near-river ground water in the particulate phase.

The chemistries of the river and ground water identified as having a dominant river source were compared to determine if there was a net change in dissolved concentrations as water moved from the river to the aquifer. Although dissolved cadmium concentrations were less than $1.0 \mu \mathrm{g} / \mathrm{L}$ in all samples (fig. 20), several of the river-source wells had cadmium concentrations exceeding that of the river. Cadmium concentrations in ground water decreased to values less than reporting levels farther away from the river in the transitional and regional ground-water wells. Dissolved lead concentrations in the ground water generally were near or less than those in the river, except during December 2000 when the river concentration $(0.14 \mu \mathrm{g} / \mathrm{L})$ was exceeded in 3 of the 16 river-source wells (fig. 20). The cause for these anomalously high concentrations (up to $1.6 \mu \mathrm{g} / \mathrm{L}$ ) in the ground water is unknown. Zinc concentrations in ground water were near or less than river concentrations in all but a few samples collected during extreme low-flow conditions in August 2001. Low leakage rates from the river during these conditions likely altered ground-water flow directions, thus complicating the comparison of the river and ground-water chemistries.
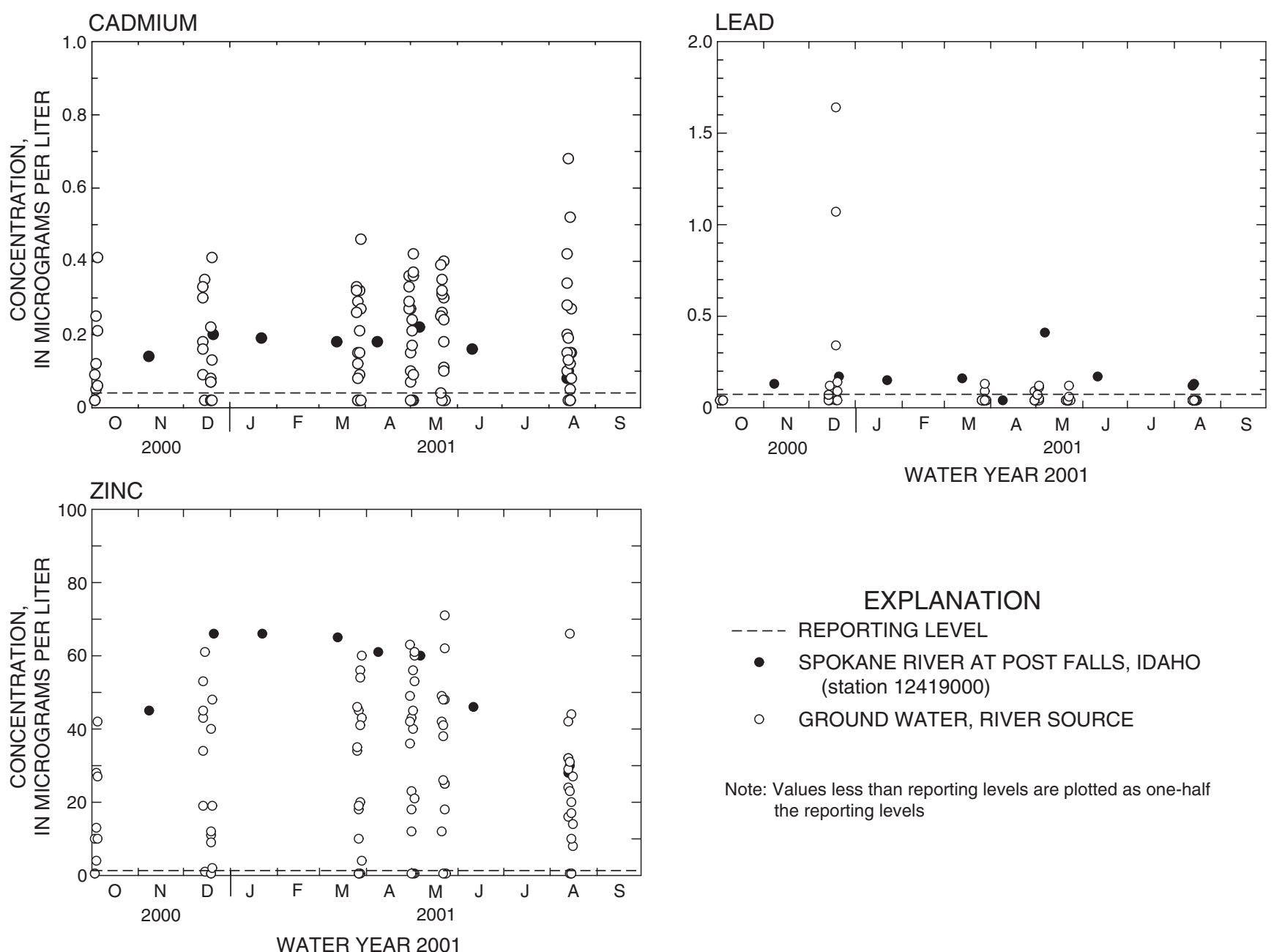

WATER YEAR 2001

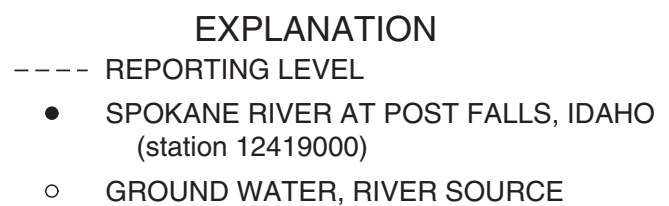

Note: Values less than reporting levels are plotted as one-half the reporting levels

Figure 20. Dissolved concentrations of cadmium, lead, and zinc in samples collected from the Spokane River at Post Falls, Idaho, and ground water identified as river source from the Spokane Valley/Rathdrum Prairie aquifer between Post Falls, Idaho, and Spokane, Washington, water year 2001. 
Table 7. Total-recoverable and dissolved cadmium, lead, and zinc concentrations of ground-water samples from monitoring wells within the Spokane Valley/Rathdrum Prairie aquifer, 2000-01

[ $\mu \mathrm{g} / \mathrm{L}$, micrograms per liter; e, estimated; ND, could not be determined; <, less than; >, greater than; --, missing data]

\begin{tabular}{|c|c|c|c|c|c|c|c|c|c|c|}
\hline \multirow[b]{2}{*}{$\begin{array}{c}\text { Well } \\
\text { number }^{1}\end{array}$} & \multirow[b]{2}{*}{ Date } & \multicolumn{3}{|c|}{ Cadmium $(\mu \mathrm{g} / \mathrm{L}$ as $\mathrm{Cd})$} & \multicolumn{3}{|c|}{ Lead $(\mu \mathrm{g} / \mathrm{L}$ as $\mathrm{Pb})$} & \multicolumn{3}{|c|}{ Zinc $(\mu \mathrm{g} / \mathrm{L}$ as $\mathrm{Zn})$} \\
\hline & & $\begin{array}{c}\text { Total } \\
\text { recover- } \\
\text { able }\end{array}$ & Dissolved & $\begin{array}{c}\text { Total } \\
\text { recover- } \\
\text { able } \\
\text { minus } \\
\text { dissolved }\end{array}$ & $\begin{array}{c}\text { Total } \\
\text { recover- } \\
\text { able }\end{array}$ & Dissolved & $\begin{array}{c}\text { Total } \\
\text { recover- } \\
\text { able } \\
\text { minus } \\
\text { dissolved }\end{array}$ & $\begin{array}{c}\text { Total } \\
\text { recover- } \\
\text { able }\end{array}$ & Dissolved & $\begin{array}{c}\text { Total } \\
\text { recover- } \\
\text { able } \\
\text { minus } \\
\text { dissolved }\end{array}$ \\
\hline 1 & 08-14-01 & $<0.04$ & $<0.04$ & $\mathrm{ND}$ & $<1.0$ & $<0.08$ & ND & 1.7 & $<1.0$ & $>0.7$ \\
\hline 2 & 08-14-01 & .70 & .68 & 0.02 & 2.6 & $<.08$ & $>2.52$ & 74 & 66 & 8 \\
\hline 4 & $08-07-00$ & $<1.0$ & $<1.0$ & $\mathrm{ND}$ & $<1.0$ & $<1.0$ & ND & 35 & 34 & 1 \\
\hline 4 & 08-13-01 & .45 & .42 & .03 & $<1.0$ & $<.08$ & ND & 46 & 42 & 4 \\
\hline 5 & $08-07-00$ & $<1.0$ & $<1.0$ & $\mathrm{ND}$ & $<1.0$ & $<1.0$ & ND & 22 & 21 & 1 \\
\hline 5 & 08-13-01 & .33 & .28 & .05 & 1.5 & $<.08$ & $>1.52$ & 36 & 29 & 7 \\
\hline 6 & 08-13-01 & .38 & .34 & .04 & $<1.0$ & $<.08$ & ND & 41 & 32 & 9 \\
\hline 8 & $07-12-00$ & $<1.0$ & $<1.0$ & $\mathrm{ND}$ & $<1.0$ & $<1.0$ & ND & 31 & 26 & 5 \\
\hline 8 & 08-09-00 & $<1.0$ & $<1.0$ & ND & $<1.0$ & $<1.0$ & ND & 34 & 32 & 2 \\
\hline 8 & $05-02-01$ & .24 & .21 & .03 & 1.3 & e.06 & 1.24 & 62 & 56 & 6 \\
\hline 8 & 08-13-01 & .22 & .20 & .02 & $<1.0$ & $<.08$ & ND & 35 & 32 & 3 \\
\hline 8 & 08-14-01 & .22 & .19 & .03 & $<1.0$ & $<.08$ & ND & 43 & 31 & 12 \\
\hline 9 & 08-09-00 & $<1.0$ & $<1.0$ & $\mathrm{ND}$ & $<1.0$ & $<1.0$ & ND & 22 & 22 & 0 \\
\hline 9 & 08-13-01 & .16 & .15 & .01 & $<1.0$ & $<.08$ & ND & 26 & 24 & 2 \\
\hline 9 & 08-14-01 & .16 & .13 & .03 & $<1.0$ & $<.08$ & ND & 24 & 23 & 1 \\
\hline 10 & 08-13-01 & .16 & .10 & .06 & $<1.0$ & $<.08$ & ND & 23 & 16 & 7 \\
\hline 11 & 08-09-00 & $<1.0$ & $<1.0$ & ND & $<1.0$ & $<1.0$ & ND & 27 & 23 & 4 \\
\hline 11 & 05-01-01 & .31 & .27 & .04 & 2.1 & $<.08$ & $>2.02$ & 51 & 43 & 8 \\
\hline 11 & 08-16-01 & .34 & .27 & .07 & 4.2 & $<.08$ & $>4.12$ & 42 & 27 & 15 \\
\hline 12 & 05-01-01 & .10 & .10 & .00 & $<1.0$ & $<.08$ & ND & 18 & 18 & 0 \\
\hline 12 & 08-16-01 & .11 & .08 & .03 & $<1.0$ & $<.08$ & ND & 12 & 8.4 & 3.6 \\
\hline 13 & 08-09-00 & $<1.0$ & $<1.0$ & ND & $<1.0$ & $<1.0$ & ND & 14 & 12 & 2 \\
\hline 13 & 05-01-01 & .15 & .15 & .00 & $<1.0$ & $<.08$ & ND & 23 & 23 & 0 \\
\hline 13 & 08-16-01 & .16 & .15 & .01 & $<1.0$ & $<.08$ & ND & 15 & 14 & 1 \\
\hline 14 & $05-02-01$ & $<.04$ & $<.04$ & $\mathrm{ND}$ & $<1.0$ & $<.08$ & ND & 1.1 & $<1.0$ & $>.1$ \\
\hline 14 & $08-15-01$ & $<.04$ & $<.04$ & ND & $<1.0$ & $<.08$ & ND & 1.5 & $<1.0$ & $>.5$ \\
\hline 15 & $05-02-01$ & $<.04$ & $<.04$ & ND & $<1.0$ & $<.08$ & ND & $<1.0$ & $<1.0$ & $\mathrm{ND}$ \\
\hline 15 & 08-13-01 & .04 & e.02 & .02 & $<1.0$ & $<.08$ & ND & 1.1 & $<1.0$ & $>.1$ \\
\hline 16 & $08-10-00$ & $<1.0$ & $<1.0$ & $\mathrm{ND}$ & $<1.0$ & $<1.0$ & ND & $<1.0$ & $<1.0$ & ND \\
\hline 19 & $08-15-01$ & .17 & .16 & .01 & $<1.0$ & $<.08$ & ND & 20 & 20 & 0 \\
\hline 21 & $08-15-01$ & .06 & .05 & .01 & $<1.0$ & $<.08$ & ND & 12 & 9.8 & 2.2 \\
\hline 22 & $08-15-01$ & .15 & .12 & .03 & $<1.0$ & $<.08$ & ND & 18 & 17 & 1 \\
\hline 23 & $08-15-01$ & .50 & .52 & -.02 & $<1.0$ & $<.08$ & ND & 44 & 44 & 0 \\
\hline 25 & 08-14-01 & $<.04$ & $<.04$ & $\mathrm{ND}$ & $<1.0$ & $<.08$ & ND & $<1.0$ & $<1.0$ & ND \\
\hline
\end{tabular}

${ }^{1}$ Number corresponds to wells listed in table 1 and shown in figure 3. 
In general, it does not appear that concentrations of cadmium, lead, and zinc increase dramatically as river water is transmitted through the streambed. Slight increases in concentrations that may be attributed to the bed sediment appear to be localized and of small scale. It is possible that some colloidal trace elements (particularly cadmium) may be transported into the near-river aquifer from the river.

Major ion, temperature, and specific conductance data provide fairly conclusive evidence of the influence of river recharge on the adjacent alluvial aquifer. However, the trace-element chemistry reveals that cadmium, lead, and zinc are not transported as far out into the aquifer as the other river-source indicators. Zinc concentrations were highest in the river and in the shallowest of the near-river wells (well 11) (fig. 21). Zinc concentrations decreased with depth in the nearriver wells and with distance away from the river.
However, the major-ion chemistry and dissolved-solids concentrations at depth and distance remained consistent and similar to the river farther out in the aquifer (example well 14, fig. 21). The decrease in zinc concentration with depth and distance does not appear to result from mixing of zinc-free regional waters and may be attributed to sorption or precipitation processes that would result in the lowering of zinc concentrations. Sorption reactions of zinc are strongly dependent on $\mathrm{pH}$; as $\mathrm{pH}$ increases zinc becomes more strongly sorbed. For example, the sorption of zinc onto hydrous ferric oxide rises from near 0 to almost 100 percent between $\mathrm{pH}$ values of 5 and about 7.5 (Stumm and Morgan, 1996, p. 542-543). The neutral pH conditions of the sampled waters ( $\mathrm{pH}$ values between 6.4 and 8.2) are consistent with the sorption of zinc. Similarly, cadmium also may react with materials in the aquifer.
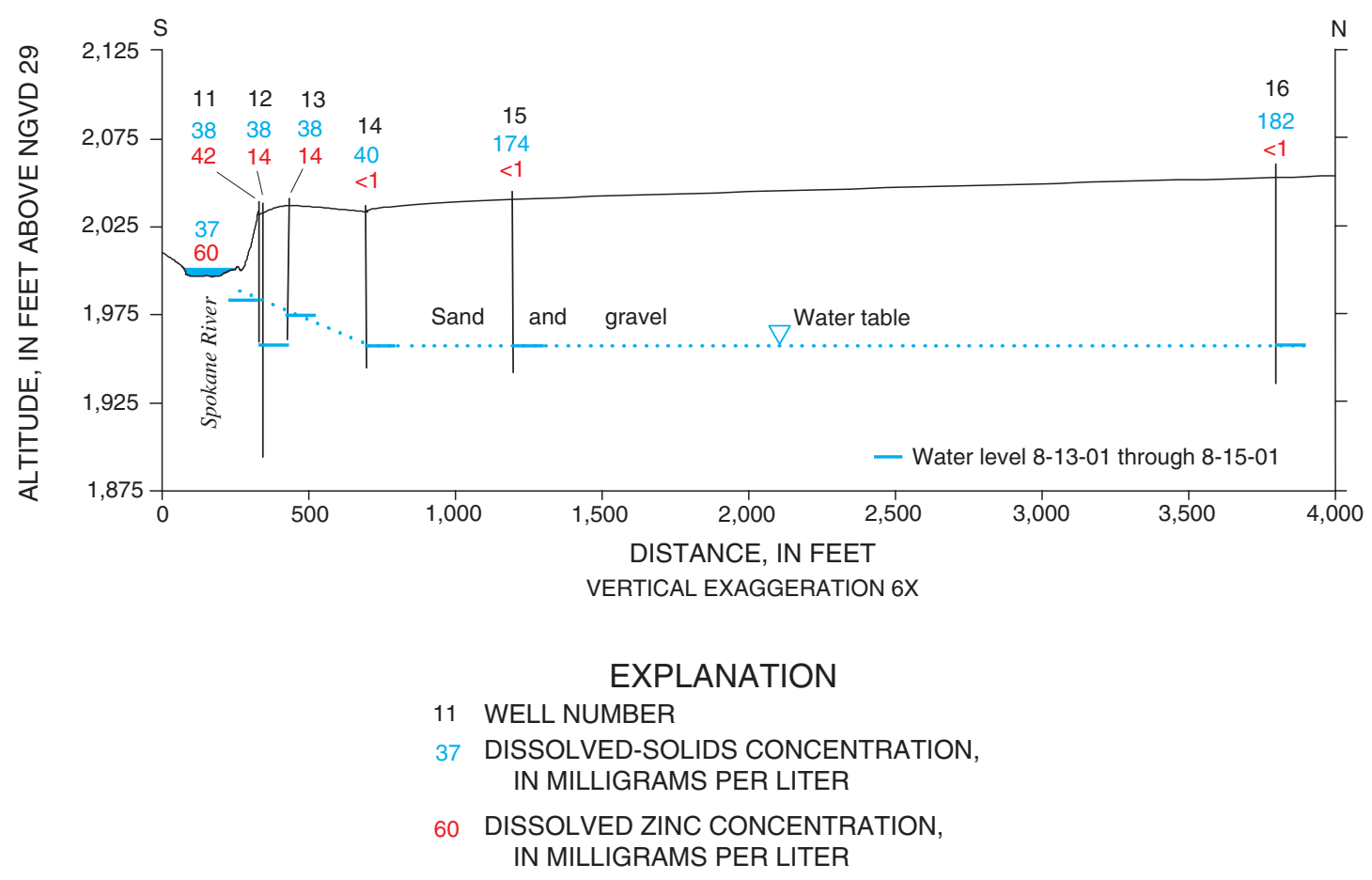

Figure 21. Median dissolved-solids and dissolved zinc concentrations of the Spokane River measured at Post Falls, Idaho, and ground water from wells 11 through 16, water year 2001. 


\section{Stable Isotopes}

The isotopic composition of precipitation generally follows a trend parallel to the global meteoric water line of Craig (1961) with a $\delta \mathrm{D} / \delta^{18} \mathrm{O}$ slope of about 8 (Coplen and others, 1999). Evaporation of water results in the enrichment of $\mathrm{D}$ and ${ }^{18} \mathrm{O}$ in the residual water resulting in a $\delta \mathrm{D} / \delta^{18} \mathrm{O}$ slope usually between 3 and 6 (Coplen and others, 1999). Because Coeur d'Alene Lake and the Spokane River undergo various degrees of evaporation, ground water derived all or in part from these surface-water sources should have an isotopic signature that is consistent with evaporation. Stable isotope values from samples of the Spokane River and ground water collected from the 25 monitoring wells had a slope of near 5.5 (fig. 22), consistent with evaporation. The stable isotopes support the hypothesis that ground water from the central part of the Spokane Valley/Rathdrum Prairie aquifer contains a component of water originating from the Spokane River and/or Coeur d'Alene Lake. However, ground water identified as transitional or regional based on major-ion chemistry data (fig. 15) generally was isotopically similar to the river and ground water determined to be of a river source (fig. 22).

Although individual isotopic values may not be distinct among the ground-water samples, the temporal variability of the river and river-influenced ground water does appear to be distinct. Variations of nearly $1 \% \circ \delta^{18} \mathrm{O}$ and $4 \% \circ \delta \mathrm{D}$ were observed in samples collected from the Spokane River between 1999 and 2001 (Bowers and others, 2003). Ground water previously identified as having a river source closely approximated the $\delta^{18} \mathrm{O}$ trend observed in the river (fig. 23). Regional ground water had isotopic values within the range observed in the river, but lacked the temporal variation observed in the river and near-river wells (fig. 23). The temporal isotopic data generally indicate that the near-river ground water includes at least a component of recharge from the river, and the recharged water moves quickly from the river to the wells.

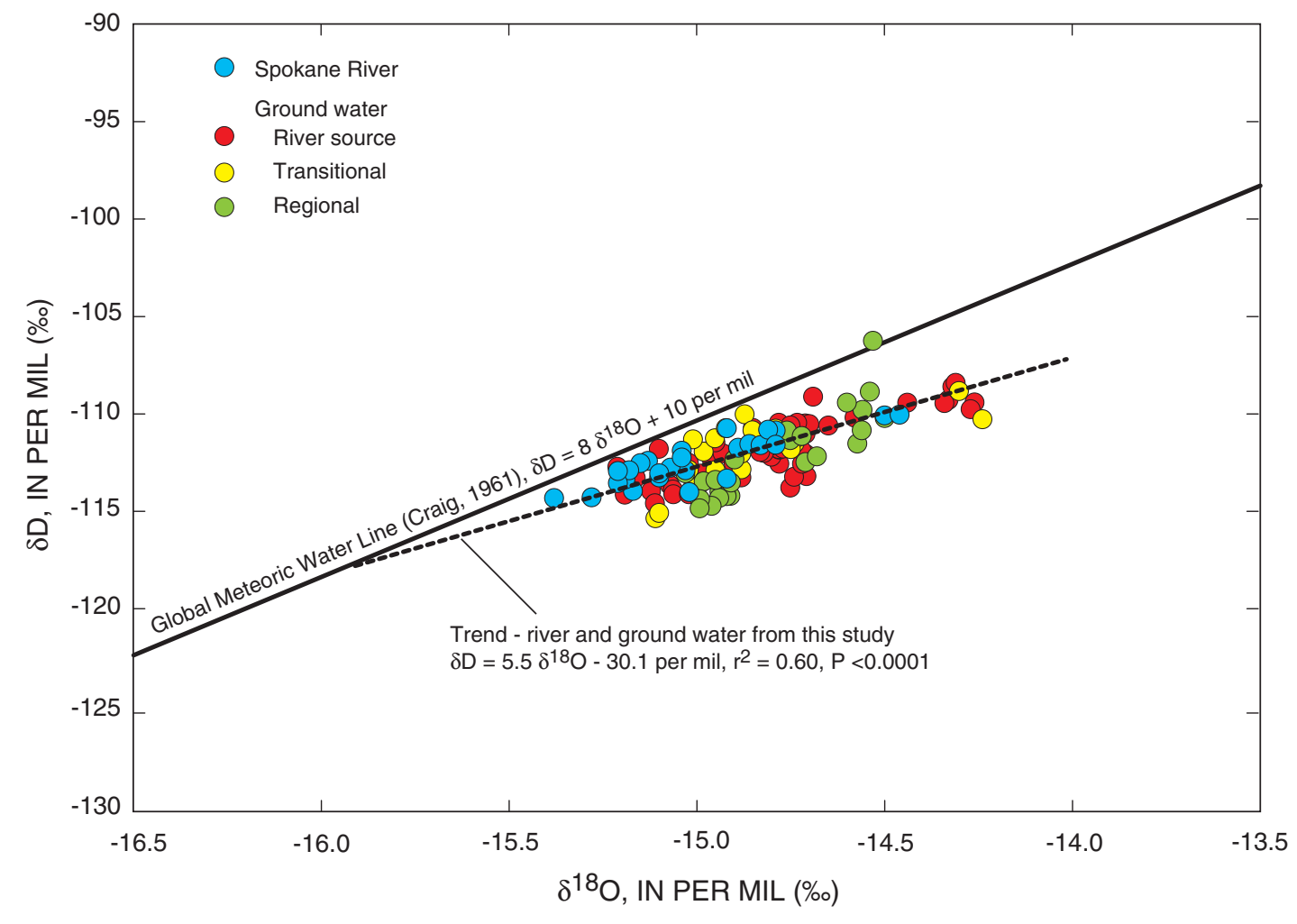

Figure 22. Relation between $\delta \mathrm{D}$ and $\delta^{18} \mathrm{O}$ in water from the Spokane River and ground water from the Spokane Valley/Rathdrum Prairie aquifer of Idaho and Washington classified as river source, transitional, and regional based on concentrations of dissolved solids, 1999-2001. 


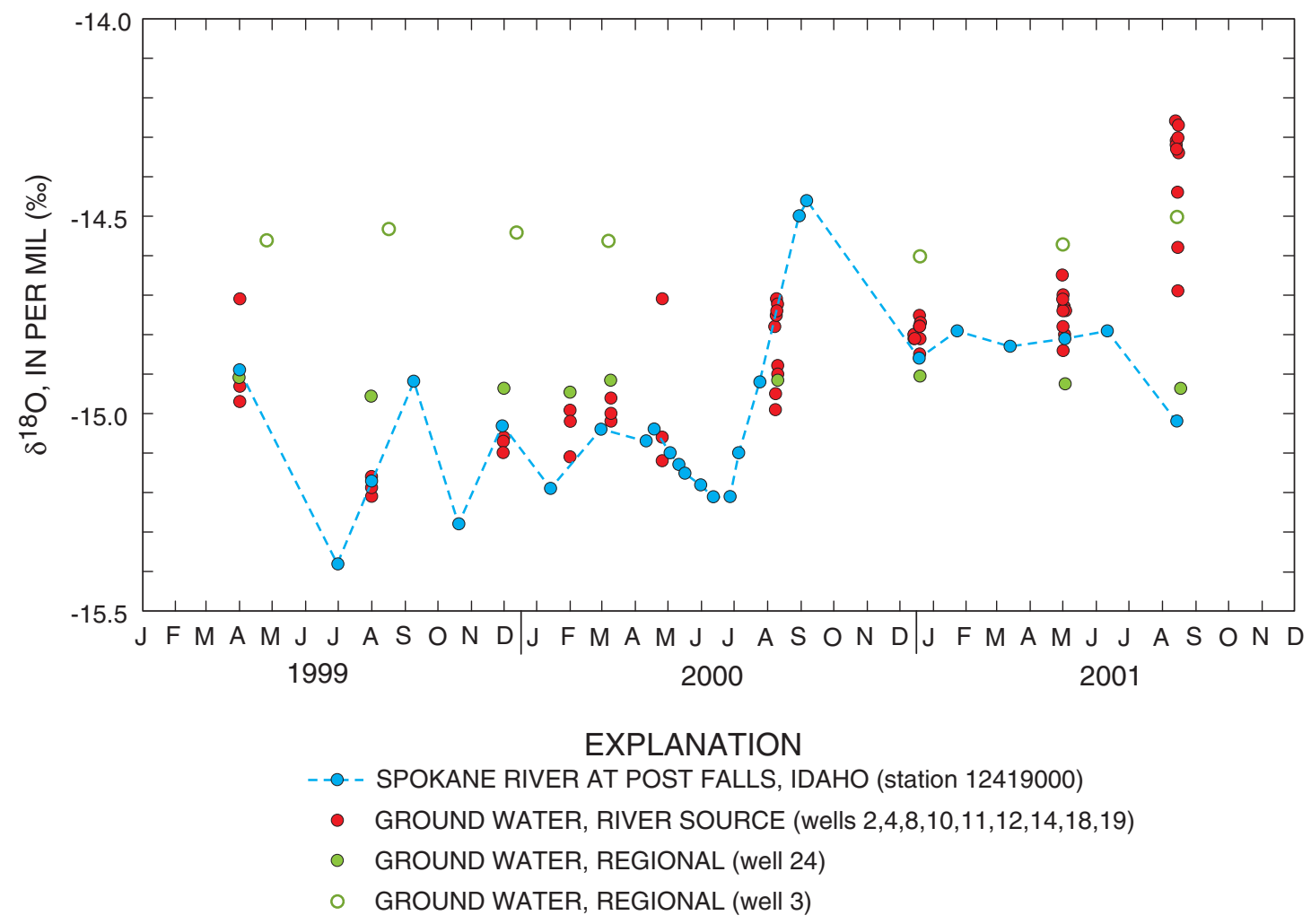

Figure 23. $\delta^{18} \mathrm{O}$ of samples from the Spokane River at Post Falls, Idaho, ground water influenced by recharge from the Spokane River, and regional ground water of the Spokane Valley/Rathdrum Prairie aquifer, 1999-2001.

\section{Temporal Variability in Water Chemistry}

Temporal water-chemistry variations in the ground water near the river appear to be associated with variability in the river. Dissolved-solids concentrations of the Spokane River ranged from 29 to $39 \mathrm{mg} / \mathrm{L}$ during 1999-2001. Dissolved-solids concentrations in samples from shallow wells adjacent to the losing reach of the river consistently followed the trend of the river, with concentrations near or slightly greater than the river (example well 11, fig. 24). Dissolved-solids concentrations in samples from the transitional and regional wells were elevated as compared to the river and were relatively unaffected by changes in the river. Zinc concentrations in the river were quite variable, ranging from 22 to $90 \mu \mathrm{g} / \mathrm{L}$ between 1999 and 2001 . Zinc concentrations in samples from wells close to the losing reach of the river followed the same pattern as the river, but at concentrations generally less than those of the river (example well 11, fig. 24). Zinc concentrations in samples from most transitional and regional wells (example wells 15 and 17, fig. 24) commonly were less than reporting levels.

Changes in ground-water chemistry in response to streamflow conditions were most apparent in samples from well 25 , which is located near the river in an area where ground water usually discharges to the river (fig. 3). The water chemistry in samples from well 25 was indicative of water from the regional flow system. However, during high streamflow in May 2001, the dissolved-solids concentrations in samples from well 25 decreased to a value of near that of the river, and zinc concentrations increased to values greater than the reporting level. This is evidence that this reach of the river changed from gaining to losing during the high streamflow event. Anomalies such as the one-time occurrence of detectable zinc in a sample from well 7 (fig. 3) during May 2001 high streamflow and the 39 to $90 \mathrm{mg} / \mathrm{L}$ range in dissolved-solids concentrations in samples from well 1 (fig. 3) also probably result from changes in river stage and recharge. Overall, it appears that periods of high streamflow had limited temporal effect on the ground-water chemistry in samples from individual wells and limited spatial effect in terms of the distance that recharged river water traveled laterally into the aquifer. It should be reiterated that during this study, ground water was sampled during relatively low flow conditions (about 44 percent of normal) for the Spokane River and that conditions in the near-river aquifer may be different during normal or above average flow conditions. 

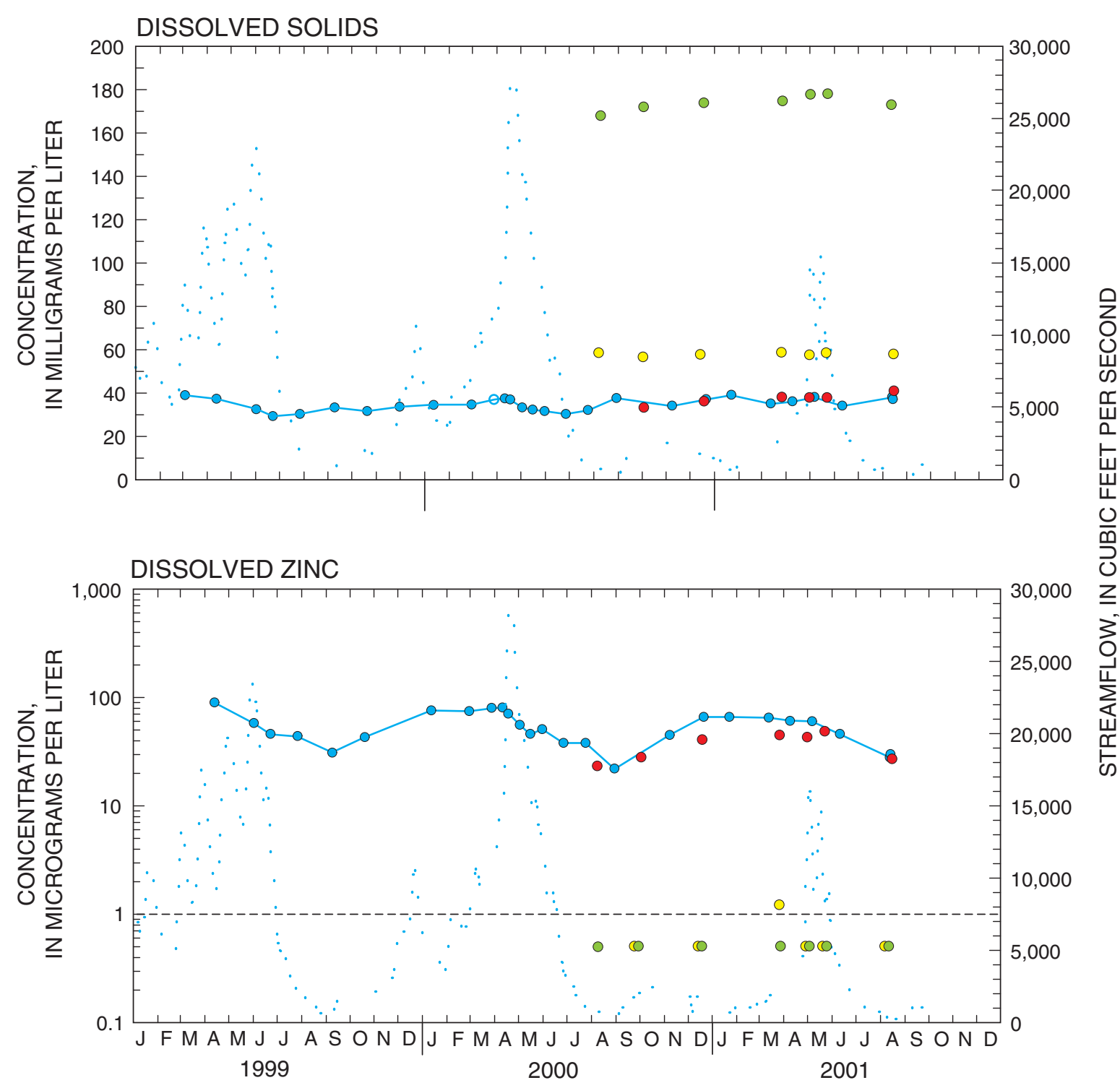

\section{EXPLANATION}

STREAMFLOW—Spokane River at Post Falls, Idaho (station 12419000)

----- MINIMUM REPORTING LEVEL

DISSOLVED-SOLIDS OR ZINC CONCENTRATIONZinc values reported as less than 1.0 microgram per liter are plotted as 0.5 microgram per liter

-_ Spokane River at Post Falls, Idaho (station 12419000)

- Ground water, river source (well 11)

- Ground water, transitional (well 17)

○ Ground water, regional (well 15)

Figure 24. Dissolved-solids and zinc concentrations of the Spokane River at Post Falls, Idaho, and ground water from selected monitoring wells within the Spokane Valley/Rathdrum Prairie aquifer between Post Falls, Idaho, and Spokane, Washington, 1999-2001. 


\section{SUMMARY}

This report describes a study conducted as part of the U.S. Geological Survey's National Water-Quality Assessment Program to examine the interaction of the Spokane River and underlying Spokane Valley/ Rathdrum Prairie aquifer, the primary source of drinking water for Spokane and surrounding communities in Idaho and Washington. Elevated concentrations of trace elements (particularly cadmium, lead, and zinc) in the bed sediment and water of the Spokane River have raised concerns about potential contamination of this ground-water resource. The river and ground water were monitored over a range of hydrologic conditions at one streamflow-gaging station and at 25 monitoring wells situated from 40 to 3,500 feet from the river. The river stage, ground-water levels, water temperature, and specific conductance were measured hourly to biweekly. Water samples were collected about monthly from 1999 through 2001 from the Spokane River, and up to nine times between June 2000 and August 2001 from the monitoring wells.

Ground-water levels and streamflow data indicate that the Spokane River loses water to the underlying aquifer along a 17-mile reach from Post Falls, Idaho, downstream to Spokane, Washington. Nested wells located near the river indicated a large downward component of flow in the aquifer. Although water levels in the near-river wells typically were several feet below the bottom of the river channel, the hydraulic gradient indicates that conditions near the river may change from saturated to unsaturated based on spatial and temporal variations. Ground-water levels in the study area responded to river stage fluctuations, but water levels near the river responded more quickly than those farther away from the river and were much more sensitive to small scale fluctuations in river stage. Downstream of the 17-mile reach between Post Falls and Spokane, ground water discharges to the river.

Calculated monthly mean losses for a 7-mile reach of the river between the gages near Post Falls and Otis Orchards ranged from about 69 to 810 cubic feet per second during water years 2000-01. Losses generally increased with increased streamflow. However, water loss from the river appeared to increase during the late summer when the water temperature in the Spokane River was at its warmest. This increased water loss is probably a result of lower water viscosity and consequent increased infiltration capacity produced by the higher water temperature.
Water temperature also appears to provide a useful tracer for ground-water recharge from the Spokane River. Water temperatures during water year 2001 varied about 22 degrees Celsius $\left({ }^{\circ} \mathrm{C}\right)$ in the river at Post Falls, and between 0.1 to $23.4^{\circ} \mathrm{C}$ in individual wells. Water temperature fluctuations in the near-river wells followed the same general pattern as the river, indicating local recharge from the river. The groundwater temperature in some near-river wells responded within hours to fluctuations in the water temperature in the river, indicating saturated conditions in those areas. Relatively stable water temperatures characterized regional ground water.

Although water levels in the alluvial aquifer appeared to respond to river fluctuations over a large area, water-quality effects appeared to be restricted to an area of the aquifer near the losing reach of the river. Dissolved-solids concentrations in the Spokane River were low, with a median of 34 milligrams per liter $(\mathrm{mg} / \mathrm{L})$, in comparison to regional ground water, with concentrations greater than $100 \mathrm{mg} / \mathrm{L}$. The effect of recharge from the river is evidenced by a reduction in the dissolved-solids concentration in the alluvial aquifer up to 3,000 feet from the river. Major-ion and stable-isotope chemistry in the river and in near-river ground water were similar and exhibited similar temporal trends. Ground water farther from the river had higher concentrations of dissolved solids and less variability in water chemistry.

Although the Spokane River loses water to the alluvial aquifer, the losses do not appear to have human health implications. Although concentrations of some trace elements in river water and bed sediment were elevated, concentrations in the river and in near-river ground water never exceeded U.S. Environmental Protection Agency drinking-water standards in the samples collected for this study. The Spokane River provides some cadmium, copper, zinc, and possibly lead to the near-river aquifer; however, concentrations of these trace elements do not increase substantially as river water is transmitted through the streambed. Dissolved cadmium, copper, and lead generally were less than 1 microgram per liter $(\mu \mathrm{g} / \mathrm{L})$ in the river and ground water. Dissolved zinc concentrations were similar in the river and the aquifer near the river, but were less than reporting levels in the aquifer farther from the river. Concentrations of arsenic were higher in ground water farther from the river, indicative of a more regional source. 
Changes in streamflow conditions had limited effect on the ground-water chemistry in the alluvial aquifer or in the distance that river water traveled from the river into the aquifer. However, water-chemistry data showed that a reach of the river near Spokane changed from gaining to losing during high streamflow in May 2001. During this study, ground water was sampled during relatively low flow conditions (about 44 percent of normal) for the Spokane River. Water chemistry and effects of surface-water/ground-water interaction may be different during normal or above average flow conditions.

Comparison of total-recoverable (whole-water, unfiltered) and dissolved (0.45-micrometer filtration) concentrations in water samples indicated that some trace elements may be transported from the river to the near-river ground water in the particulate phase. Zinc and cadmium appear to be transported from the Spokane River to the alluvial aquifer primarily in the dissolved phase, although some particulate transport was evident. Lead was detected in five whole-water samples from the near-river aquifer at concentrations up to $4.2 \mu \mathrm{g} / \mathrm{L}$; however, the dissolved lead concentrations were less than $0.08 \mu \mathrm{g} / \mathrm{L}$ in the accompanying filtered samples.

Cadmium and zinc originating from the river water appear to be restricted to a narrow zone in the near-river aquifer. Cadmium and zinc concentrations generally were highest in the river and in the aquifer near the river, decreasing with depth and distance away from the river. In contrast to cadmium and zinc, other water-quality constituents such as major ions, water temperature, and stable isotopes reflected river water to a greater depth and distance from the river. The decrease in cadmium and zinc concentrations with depth and distance may reflect processes such as sorption and/or precipitation. The neutral $\mathrm{pH}$ of the aquifer water ( $\mathrm{pH}$ values between 6.4 and 8.2 ) would promote these processes. These processes also may explain the apparent loss of cadmium and zinc load in the river downstream where ground water returns to the river.

\section{REFERENCES CITED}

Beckwith, M.A., 2002, Selected trace-element and synthetic-organic compound data for streambed sediment from the Clark Fork-Pend Oreille and Spokane River Basins, Montana, Idaho, and Washington, 1998: U.S. Geological Survey OpenFile Report 02-336, 26 p.
2003, Summary of surface-water-quality data collected for the Northern Rockies Intermontane Basins National Water-Quality Assessment Program in the Clark Fork-Pend Oreille and Spokane River Basins, Montana, Idaho, and Washington, water years 1999-2001: U.S. Geological Survey Open-File Report 02-472, 47 p.

Berenbrock, Charles, Bassick, M.D., Rogers, T.L., and Garcia, S.P., 1995, Depth to water, 1991, in the Rathdrum Prairie, Idaho; Spokane River valley, Washington; Moscow-Lewiston-Grangeville area, Idaho; and selected intermontane valleys, eastcentral Idaho: U.S. Geological Survey WaterResources Investigations Report 94-4087, 2 sheets.

Bolke, E.L., and Vaccaro, J.V., 1979, Selected hydrologic data for Spokane Valley, Spokane, Washington, 1977-78: U.S. Geological Survey Open-File Report 79-333, 98 p.

1981, Digital-model simulation of the hydrologic flow system, with emphasis on ground water, in the Spokane Valley, Washington and Idaho: U.S. Geological Survey Open-File Report 801300, $43 \mathrm{p}$.

Bookstrom, A.A., Box, S.E., Campbell, J.K., Foster, K.I., and Jackson, B.L., 2001, Lead-rich sediments, Coeur d'Alene River Valley, Idaho-area, volume, tonnage, and lead content: U.S. Geological Survey Open-File Report 01-140, 44 p.

Bowers, C.L., Caldwell, R.R., and Dutton, D.M., 2003, Water-quality, streambed-sediment, and biologic data from the Clark Fork-Pend Oreille and Spokane River basins, Montana, Idaho, and Washington, 1998-2001: U.S. Geological Survey OpenFile Report 03-292, 203 p.

Box, S.E., and Wallis, J.C., 2002, Surficial geology along the Spokane River, Washington and its relationship to the metal content of sediments (IdahoWashington stateline to Latah Creek confluence): U.S. Geological Survey Open-File Report 02-126, $76 \mathrm{p}$.

Briar, D.W., Lawlor, S.M., Stone, M.A.J., Parliman, D.J., Schaefer, J.L., and Kendy, Eloise, 1996, Ground-water levels in the Intermontane Basins of the Northern Rocky Mountains, Montana and Idaho: U.S. Geological Survey Hydrologic Investigations Atlas HA-738-B, 1 sheet, scale $1: 750,000$. 
Clark, G.M., 2003, Occurrence and transport of cadmium, lead, and zinc in the Spokane River Basin, Idaho and Washington, water years 1999-2001: U.S. Geological Survey Water-Resources Investigations Report 02-4183, $37 \mathrm{p}$.

Constanz, J., and Murphy, F., 1991, The temperature dependence of ponded infiltration under isothermal conditions: Journal of Hydrology, v. 122, p. 119-128.

Coplen, T.B., Herczeg, A.L., and Barnes, C.J., 1999, Isotope engineering - using stable isotopes of the water molecule itself to solve practical problems, in Cook, P.G., and Herczeg, A.L., eds., Environmental tracers in subsurface: Boston, Kluwer Academic Publishers, p. 79-110.

Coplen, T.B., Wildman, J.D., and Chen, Julie, 1991, Improvements in the gaseous hydrogen-water equilibration technique for hydrogen isotope ratio analysis: Analytical Chemistry, v. 63, p. 910-912.

Craig, H., 1961, Isotopic variations in meteoric waters: Science, v. 133, p. 1702-1703.

Drost, B.W., and Seitz, H.R., 1978, Spokane ValleyRathdrum Prairie aquifer, Washington and Idaho: U.S. Geological Survey Open-File Report 77-829, $79 \mathrm{p}$.

EMCON, 1992, Deer Park ground water characterization study, hydrogeologic summary report, v. 1: Bothell, Washington, EMCON Northwest, Inc., project 0622-001.02, $83 \mathrm{p}$.

Epstein, Samuel, and Mayeda, T.K., 1953, Variation of ${ }^{18} \mathrm{O}$ content of waters from natural sources: Geochimica et Cosmochimica Acta, v. 4, no. 5, p. 213-224.

Faires, L.M., 1993, Methods of analysis by the U.S. Geological Survey National Water Quality Laboratory-Determination of metals in water by inductively coupled plasma-mass spectrometry: U.S. Geological Survey Open-File Report 92-634, 28 p.

Fishman, M.J., ed., 1993, Methods of analysis by the U.S. Geological Survey National Water Quality Laboratory-Determination of inorganic and organic constituents in water and fluvial sediments: U.S. Geological Survey Open-File Report 93-125, $217 \mathrm{p}$.

Fishman, M.J., and Friedman, L.C., 1989, Methods for determination of inorganic substances in water and fluvial sediments: U.S. Geological Survey Techniques of Water-Resources Investigations, book 5, chap. A1, 545 p.
Garbarino, J.R., 1999, Methods of analysis by the U.S. Geological Survey National Water Quality Laboratory-Determination of dissolved arsenic, boron, lithium, selenium, strontium, thallium, and vanadium using inductively coupled plasma-mass spectrometry: U.S. Geological Survey Open-File Report 99-093, 31 p.

Garbarino, J.R., and Struzeski, T.M., 1998, Methods of analysis by the U.S. Geological Survey National Water Quality Laboratory-Determination of elements in whole-water digests using inductively coupled plasma-optical emission spectrometry and inductively coupled plasmamass spectrometry: U.S. Geological Survey Open-File Report 98-165, 101 p.

Gearhart, Christina, and Buchanan, J.P., 2000, The hydraulic connection between the Spokane River and the Spokane-aquifer gaining and losing reaches of the Spokane River from State line, Idaho to Spokane, Washington: Cheney, Washington, prepared for the Spokane County Water Quality Management Program, 106 p.

Gerstel, W.J., and Palmer, S.P., 1994, Geologic and geophysical mapping of the Spokane aquiferRelevance to growth management: Washington Geology, v. 22, p. 18-24.

Gilliom, R.J., Alley, W.M., and Gurtz, M.E., 1995, Design of the National Water-Quality Assessment Program-Occurrence and distribution of water-quality conditions: U.S. Geological Survey Circular 1112, 33 p.

Grosbois, C.A., Horowitz, A.J., Smith, J.J., and Elrick, K.A., 2001, The effect of mining and related activities on the sediment-trace element geochemistry of Lake Coeur d'Alene, Idaho, USA, Part III, Downstream effects- the Spokane River Basin: Hydrological Processes, v. 15, p. 855-875.

Hoffman, G.L., Fishman, M.J., and Garbarino, J.R., 1996, Methods of analysis by the U.S. Geological Survey National Water Quality Laboratory-Inbottle acid digestion of whole-water samples: U.S. Geological Survey Open-File Report 96225, $28 \mathrm{p}$.

Horowitz, A.J., Elrick, K.A., Robbins, J.A., and Cook, R.B., 1995, A summary of the effects of mining and related activities on the sediment-trace element geochemistry of Lake Coeur d'Alene, Idaho, USA: Journal of Geochemical Exploration, v. 52, p. 135-144. 
Idaho Department of Environmental Quality, 2000, The Spokane Valley-Rathdrum Prairie aquifer atlas: Idaho Department of Environmental Quality, 24 p.

Jones, S.R., and Garbarino, J.R., 1999, Methods of analysis by the U.S. Geological Survey National Water Quality Laboratory-Determination of arsenic and selenium in water and sediment by graphite furnace-atomic absorption spectrometry: U.S. Geological Survey Open-File Report 98-639, $39 \mathrm{p}$.

Kimbrough, R.A., Ruppert, G.P., Wiggins, W.C., Smith, R.R., Knowles, S.M., and Renslow, V.F., 2002, Water resources data, Washington, water year 2001: U.S. Geological Survey Water-Data Report WA-01-1, $576 \mathrm{p}$.

Kimbrough, R.A., Smith, R.R., Ruppert, G.P., Wiggins, W.D., Knowles, S.M., and Renslow, V.F., 2001, Water resources data, Washington, water year 2000: U.S. Geological Survey Water-Data Report WA-00-1, $541 \mathrm{p}$.

Koterba, M.T., Wilde, F.D., and Lapham, W.W., 1995, Ground-water data collection protocols and procedures for the National Water-Quality Assessment Program-Collection and documentation of water-quality samples and related data: U.S. Geological Survey Open-File Report 95-399, 113 p.

Long, K.R., 1998, Production and disposal of mill tailings in the Coeur d'Alene mining region, Shoshone County, Idaho-Preliminary estimates: U.S. Geological Survey Open-File Report 98-595, 14 p.

Maret, T.R., and Skinner, K.D., 2000, Concentrations of selected trace elements in fish tissue and streambed sediment in the Clark Fork-Pend Oreille and Spokane River Basins, Washington, Idaho, and Montana, 1998: U.S. Geological Survey Water-Resources Investigations Report 00-4159, $26 \mathrm{p}$.

Marti, P.B., and Garrigues, R.S., 2001, Spokane River/aquifer interaction project results, MayNovember 1999: Olympia, Washington State Department of Ecology publication no. 01-03-024, $40 \mathrm{p}$.

McLain, Betty, 1993, Methods of analysis by the U.S. Geological Survey National Water Quality Laboratory-Determination of chromium in water by graphite furnace atomic absorption spectrophotometry: U.S. Geological Survey Open-File Report 93-449, $16 \mathrm{p}$.
Molenaar, Dee, 1988, The Spokane aquifer, Washington-Its geologic origin and water-bearing and water-quality characteristics: U.S. Geological Survey Water-Supply Paper 2265, 74 p.

Mueller, D.K., Martin, J.D., and Lopes, T.J., 1997, Quality-control design for surface-water sampling in the National Water-Quality Assessment Program: U.S. Geological Survey Open-File Report 97-223, 17 p.

Parliman, D.J., Seitz, H.R., and Jones, M.L., 1980, Ground-water quality in north Idaho: U.S. Geological Survey Open-File Report 80-596, 34 p.

Piper, A.M., and La Rocque, G.A., Jr., 1944, Watertable fluctuations in the Spokane Valley and contiguous area Washington-Idaho: U.S. Geological Survey Water-Supply Paper 889-B, p. 83-139.

Pritt, J.W., and Raese, J.W., 1995, Quality assurance/quality control manual-National Water Quality Laboratory: U.S. Geological Survey Open-File Report 95-443, 35 p.

Prudic, D.E., 1989, Documentation of a computer program to simulate stream-aquifer relations using a modular, finite-difference, ground-water flow model: U.S. Geological Survey Open-File Report 88-729, $113 \mathrm{p}$.

Shelton, L.R., 1994, Field guide for collecting and processing stream-water samples for the National Water-Quality Assessment Program: U.S. Geological Survey Open-File Report 94-455, 42 p.

Spruill, T.B., 1993, Preliminary evaluation of hydrogeology and ground-water quality in valley sediments in the vicinity of Killarney Lake, Kootenai County, Idaho: U.S. Geological Survey WaterResources Investigations Report 93-4091, 41 p.

Stoffel, K.L., Joseph, N.L., Waggoner, S.Z., Gulick, C.W., Korosec, M.A., and Bunning, B.B., 1991, Geologic map of Washington-northeast quadrant: Olympia, Washington Division of Geology and Earth Resources, Geologic Map GM-39, scale 1:250,000, sheet 1 .

Stone, M.A.J., Parliman, D.J., and Schaefer, J.L., 1996, Selected geohydrologic data from a regional aquifer-system analysis of the northern Rocky Mountains intermontane basins in Idaho: U.S. Geological Survey Open-File Report 96-207, 30 p.

Stumm, Werner, and Morgan, J.J., 1996, Aquatic chemistry-Chemical equilibria and rates in natural waters (3d ed.): New York, Wiley, 1,022 p. 
Tuck, L.K., Briar, D.W., and Clark, D.W., 1996, Geologic history and hydrogeologic units of Intermontane Basins of the northern Rocky Mountains, Montana and Idaho: U.S. Geological Survey Hydrologic Investigations Atlas HA-738-A, scale $1: 750,000$, sheet 1 .

U.S. Census Bureau, 2002, State \& county quickfacts: accessed August 5, 2002, at URL http://quickfacts.census.gov/qfd/

U.S. Environmental Protection Agency, 2000, Sole Source Aquifer Protection Program overview: accessed June 6, 2001, at URL http://www.epa.gov/OGWDW/swp/ssa.html 2002a, 2002 edition of the drinking water standards and health advisories: U.S. Environmental Protection Agency, EPA-822-R-02-038, 19 p. 2002b, National recommended water quality criteria-2002: EPA-822-R-02-047, 33 p.

U.S. Geological Survey, 2001, Estimated use of water in the United States in 1995: accessed August 6, 2002, at URL

http://water.usgs.gov/watuse/pdf1995/html
Western Regional Climate Center, 1998, NCDC 19641990 monthly normal: accessed January 26, 2001, at URL http://www.wrcc.dri.edu/

Wilde, F.D., and Radtke, D.B., 1998, National field manual for the collection of water-quality data-Field measurements: U.S. Geological Survey Techniques of Water-Resources Investigations, book 9, chap. A6 [variously paged].

Woods, P.F., 2001, Concentrations and loads of cadmium, lead, and zinc measured during the 1999 water year within the Spokane River Basin, Idaho and Washington: U.S. Geological Survey OpenFile Report 00-411, 32 p.

Woods, P.F., and Beckwith, M.A., 1997, Nutrient and trace-element enrichment of Coeur d'Alene Lake, Idaho: U.S. Geological Survey Water-Supply Paper 2485, $93 \mathrm{p}$.

Zheng, Yi, 1995, Distribution of major and trace metals in groundwater of the Spokane aquifer, northeastern Washington-Water quality and river/aquifer interaction: Cheney, Eastern Washington University, unpublished M.S. thesis, $123 \mathrm{p}$. 


\section{APPENDIX}




\section{Well-Numbering System}

Wells are assigned well numbers (1-25; fig. 3; table 1) and location numbers that describe the geographic position within the rectangular grid system used for the subdivision of public lands. The locationnumbering system consists of 14 characters. The first three characters specify the township and its position north $(\mathrm{N})$ of the Willamette Base Line in Washington, the Boise Base Line in Idaho, or the Baseline in Montana. The next three characters specify the range and its position west (W) or east (E) of the Willamette meridian in Washington, the Boise meridian in Idaho, or the Principal meridian in Montana. The next two numbers represent the section number. The next four characters sequentially designate the quarter (160-acre tract), quarter-quarter (40-acre tract), quarter-quarterquarter (10-acre tract), and the quarter-quarter-quarter- quarter ( $2 \frac{1 / 2}{2}$-acre tract). The locations of quarter subdivisions within a section are designated A, B, C, D in a counterclockwise direction, beginning in the northeast quadrant. The final two characters are a sequence number assigned to differentiate multiple wells within a single quarter-quarter-quarter-quarter section; for example, a well location reported as $26 \mathrm{~N} 43 \mathrm{E} 31 \mathrm{CBBC} 01$ is the first well inventoried in the SW1/4NW1/4NW1/4SW1/4 section 31, township 26 north, range 43 east.

Wells also are assigned 15-digit station-identification numbers (table 1). These numbers represent the approximate latitude and longitude of each well (first 13 digits) plus the sequence number (last 2 digits). However, some station-identification numbers differ (table 1) from the latitude and longitude where wells were recently field checked and latitudes and longitudes were determined with greater accuracy.

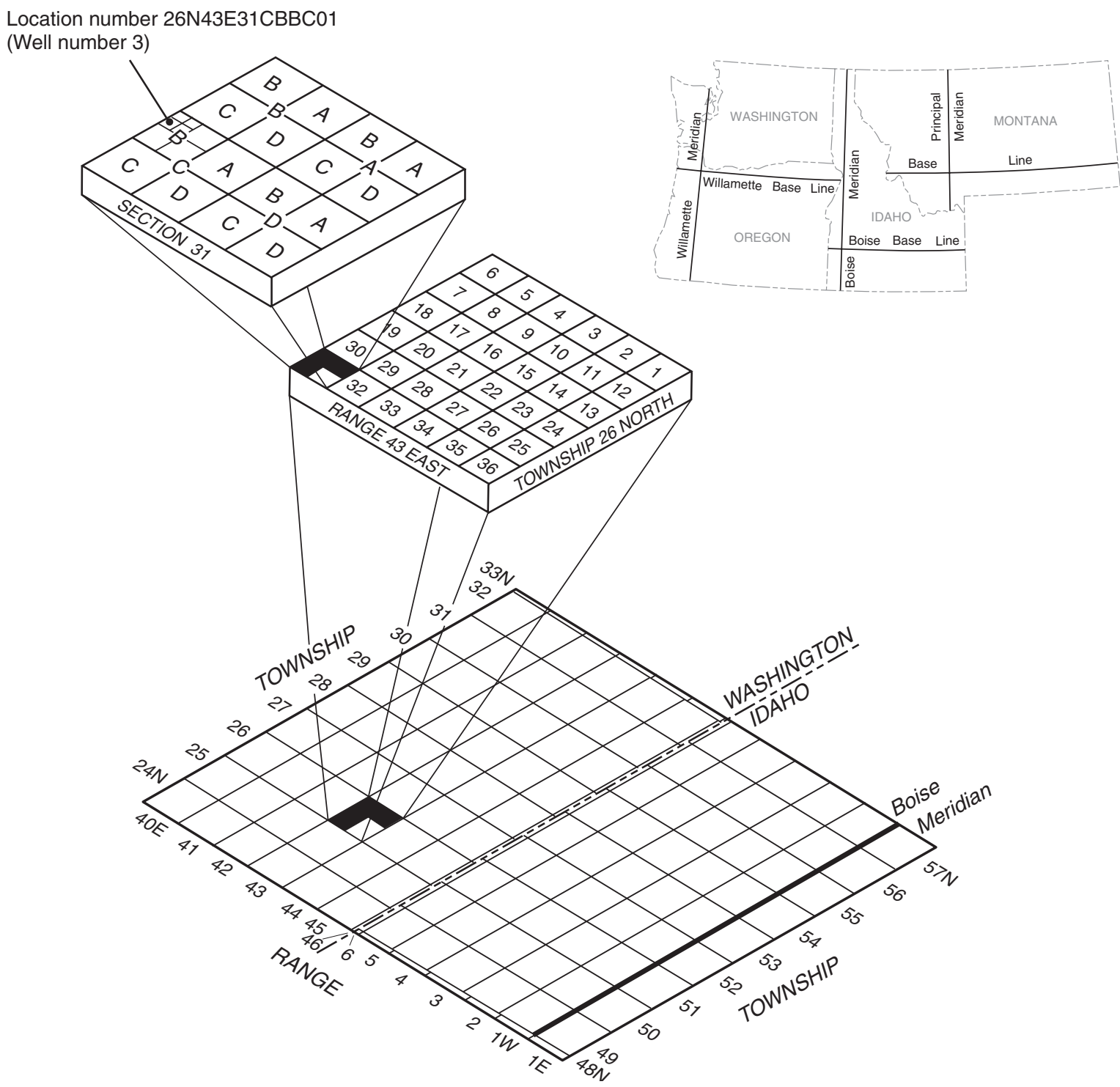




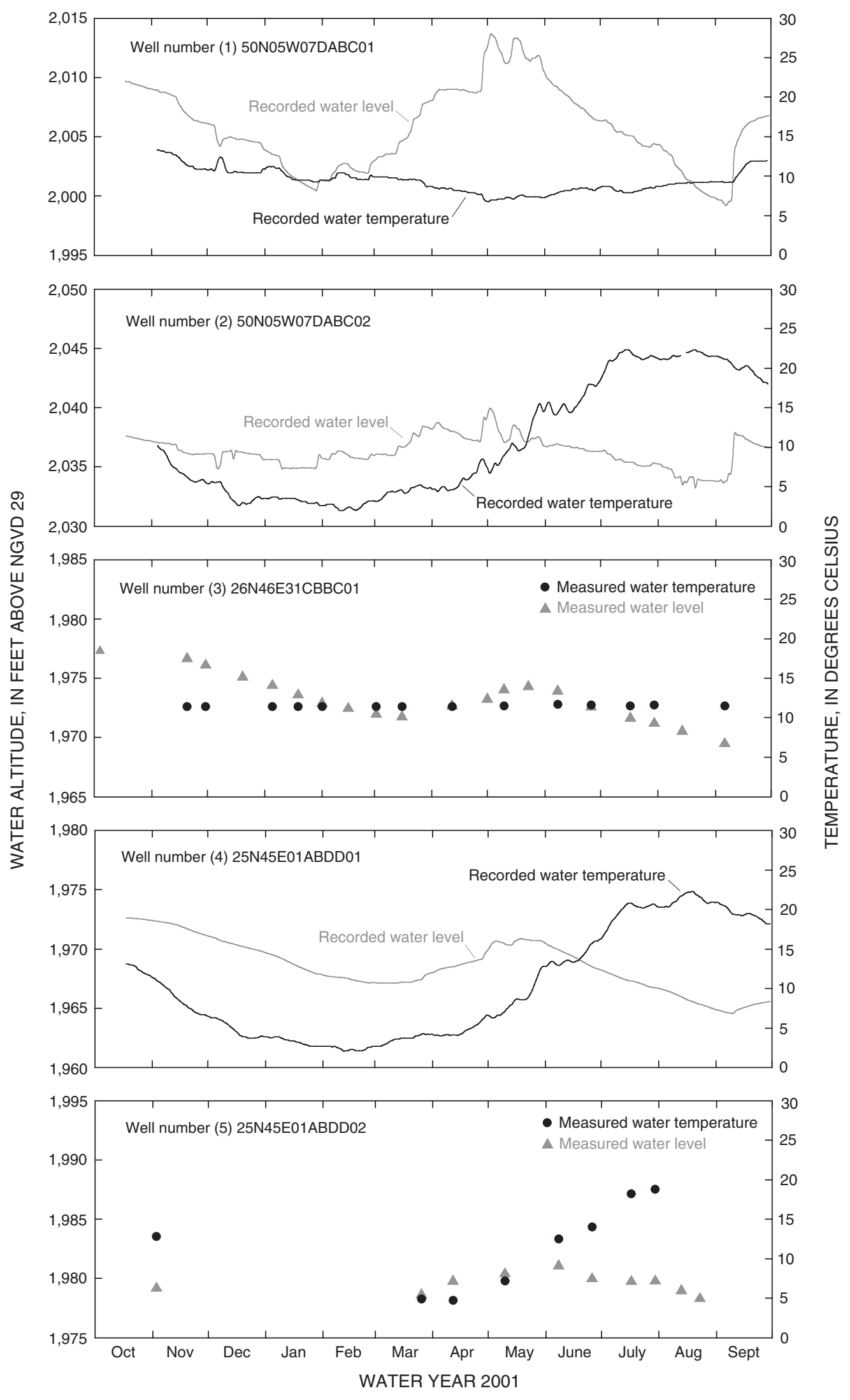

Figure 25. Ground-water altitude and water temperature measured in 25 monitoring wells within the Spokane Valley/Rathdrum Prairie aquifer between Post Falls, Idaho, and Spokane, Washington, water year 2001. 


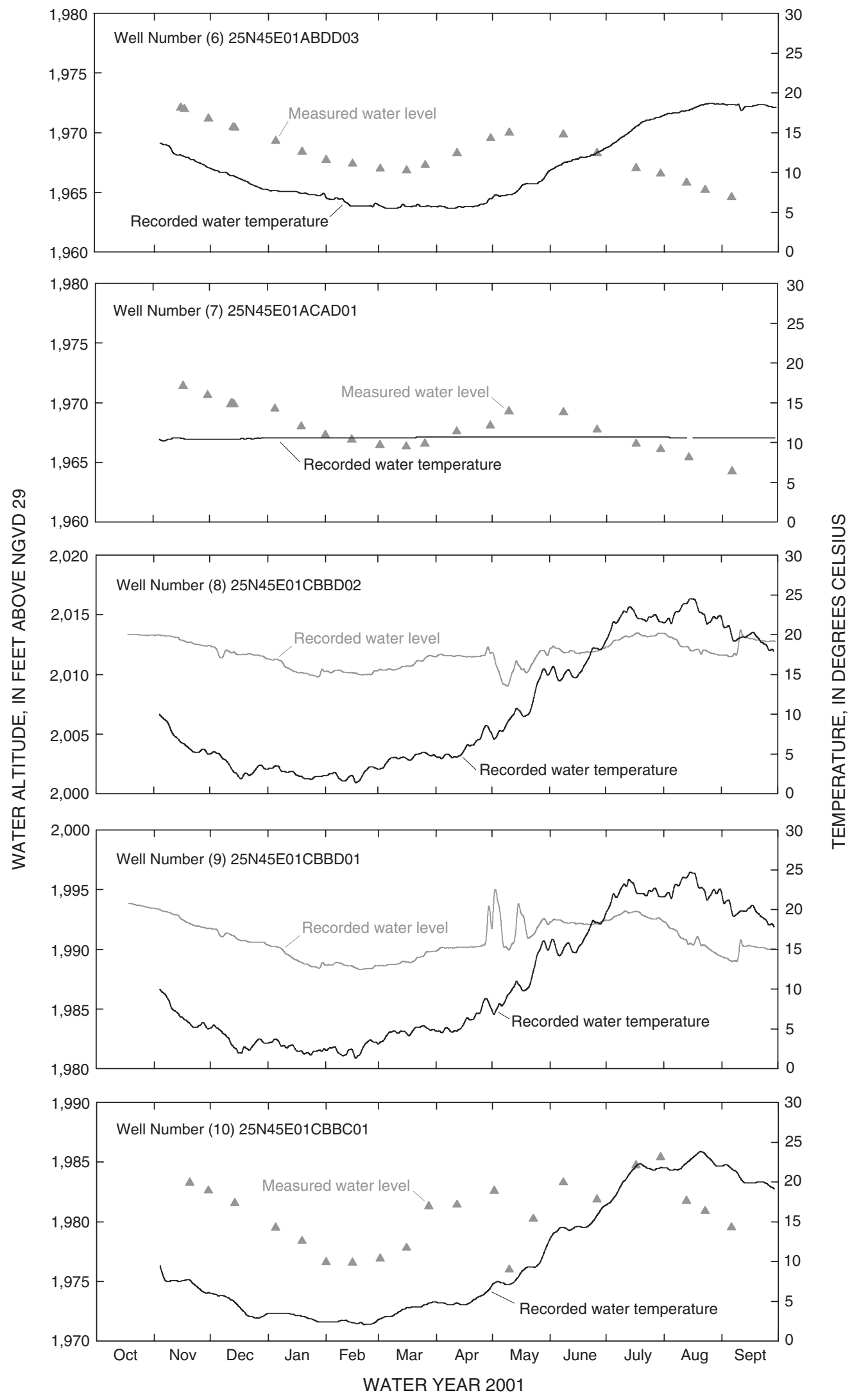

Figure 25. Ground-water altitude and water temperature measured in 25 monitoring wells within the Spokane Valley/Rathdrum Prairie aquifer between Post Falls, Idaho, and Spokane, Washington, water year 2001 (Continued). 


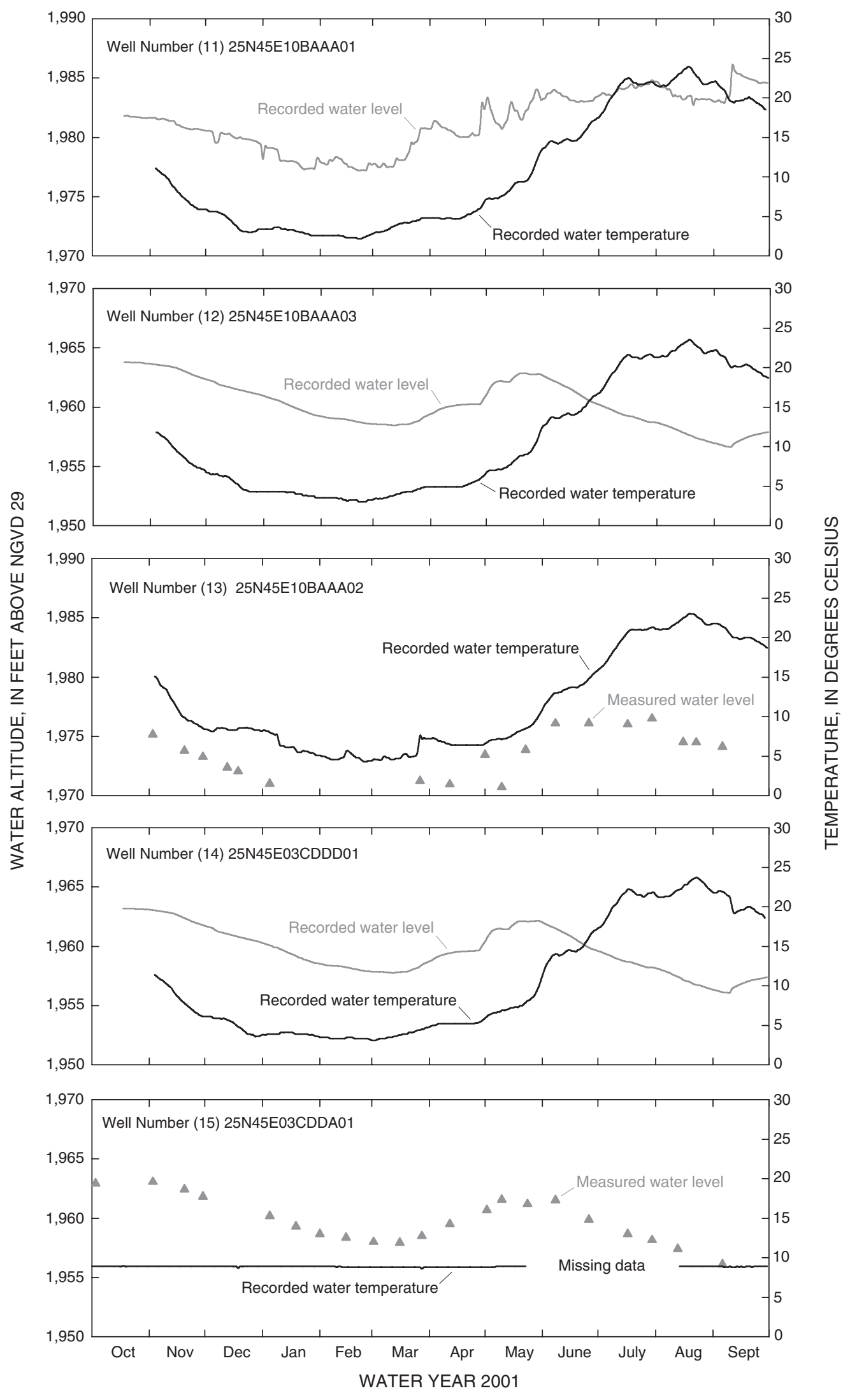

Figure 25. Ground-water altitude and water temperature measured in 25 monitoring wells within the Spokane Valley/Rathdrum Prairie aquifer between Post Falls, Idaho, and Spokane, Washington, water year 2001 (Continued). 


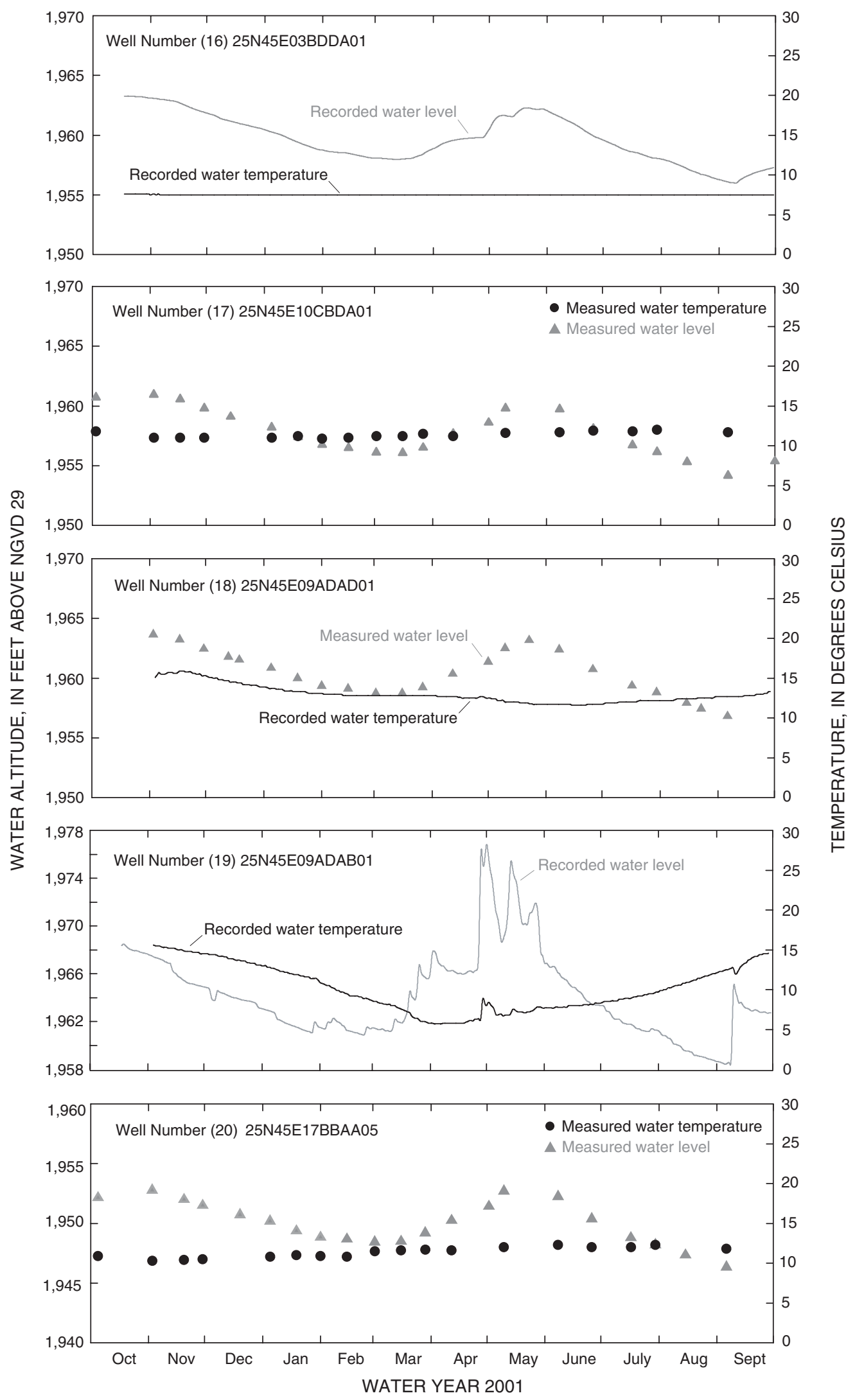

Figure 25. Ground-water altitude and water temperature measured in 25 monitoring wells within the Spokane Valley/Rathdrum Prairie aquifer between Post Falls, Idaho, and Spokane, Washington, water year 2001 (Continued). 


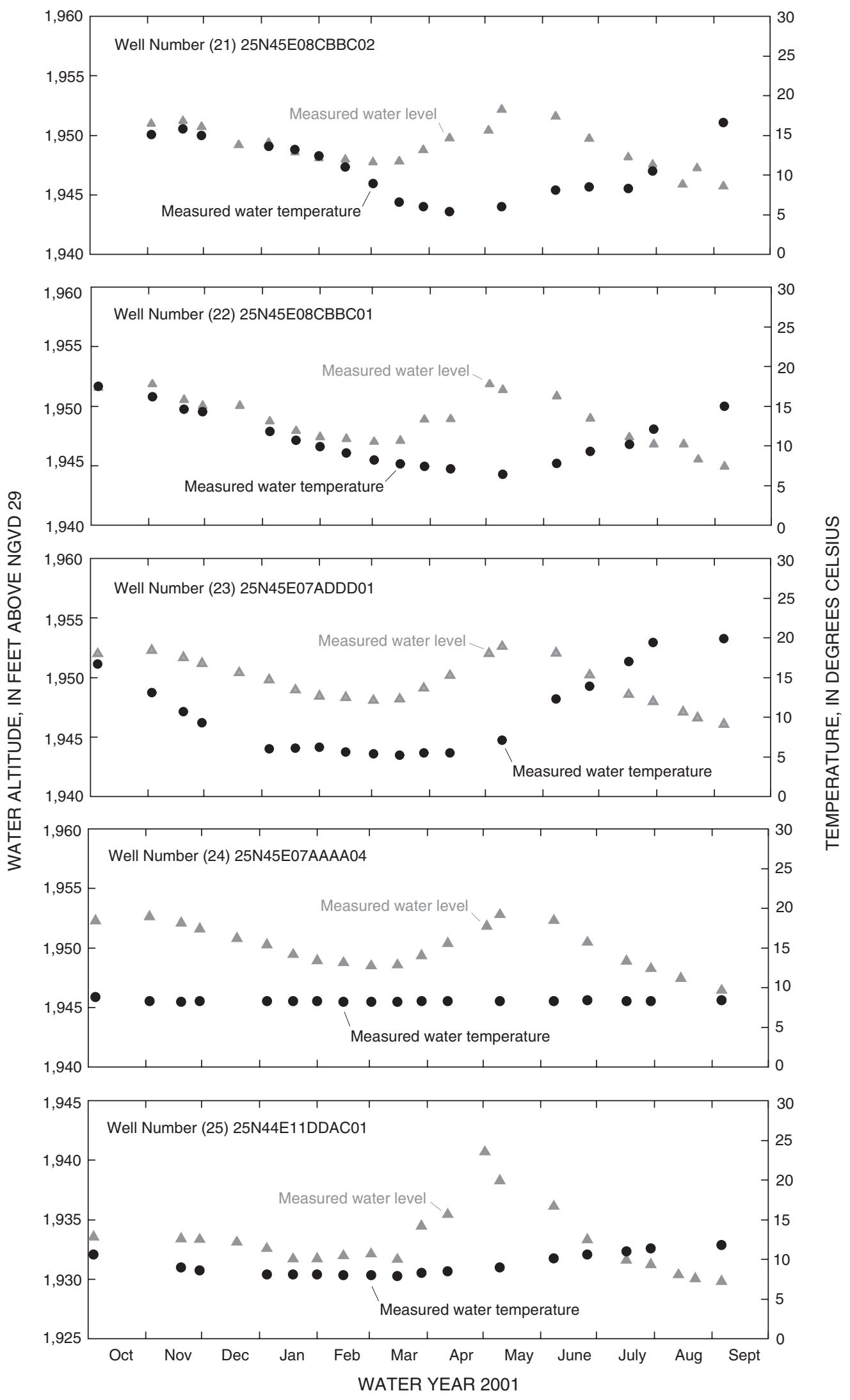

Figure 25. Ground-water altitude and water temperature measured in 25 monitoring wells within the Spokane Valley/Rathdrum Prairie aquifer between Post Falls, Idaho, and Spokane, Washington, water year 2001 (Continued). 
Table 8. Selected trace-element concentrations of the Spokane River at Post Falls, Idaho, and ground water from monitoring wells within the Spokane Valley/Rathdrum Prairie aquifer, 1999-2001

[e, estimated; $\mu \mathrm{g} / \mathrm{L}$, micrograms per liter; $<$, less than; --, no data]

\begin{tabular}{|c|c|c|c|c|c|c|c|c|c|}
\hline $\begin{array}{l}\text { Site } 1 / \text { well } \\
\text { number }^{2}\end{array}$ & Date & $\begin{array}{l}\text { Arsenic } \\
\text { total } \\
\text { recover- } \\
\text { able } \\
\text { ( } \mu \mathrm{g} / \mathrm{L} \text { as } \\
\text { As) }\end{array}$ & $\begin{array}{c}\text { Arsenic, } \\
\text { dissolved } \\
(\mu \mathrm{g} / \mathrm{L} \text { as } \\
\text { As) }\end{array}$ & $\begin{array}{l}\text { Cadmium, } \\
\text { total } \\
\text { recover- } \\
\text { able } \\
(\mu \mathrm{g} / \mathrm{L} \text { as } \\
\text { Cd) }\end{array}$ & $\begin{array}{c}\text { Cadmium, } \\
\text { dissolved } \\
(\mu \mathrm{g} / \mathrm{L} \text { as } \\
\text { Cd })\end{array}$ & $\begin{array}{l}\text { Lead, total } \\
\text { recover- } \\
\text { able } \\
(\mu \mathrm{g} / \mathrm{L} \text { as } \\
\mathrm{Pb})\end{array}$ & $\begin{array}{l}\text { Lead, } \\
\text { dissolved } \\
(\mu \mathrm{g} / \mathrm{L} \text { as } \\
\mathrm{Pb})\end{array}$ & $\begin{array}{l}\text { Zinc, total } \\
\text { recover- } \\
\text { able } \\
(\mu \mathrm{g} / \mathrm{L} \text { as } \\
\mathrm{Zn})\end{array}$ & $\begin{array}{c}\text { Zinc, } \\
\text { dissolved } \\
(\mu \mathrm{g} / \mathrm{L} \text { as } \\
\mathrm{Zn})\end{array}$ \\
\hline \multirow[t]{27}{*}{ Spokane River } & 04-13-99 & $<1.0$ & $<1.0$ & $<1.0$ & $<1.0$ & 2.1 & $<1.0$ & 82 & 90 \\
\hline & 05-19-99 & $<1.0$ & $<1.0$ & $<1.0$ & $<1.0$ & $<1.0$ & $<1.0$ & $<40$ & 60 \\
\hline & 06-02-99 & 1.6 & $<1.0$ & $<1.0$ & $<1.0$ & 7.7 & $<1.0$ & 69 & 58 \\
\hline & 06-23-99 & $<1.0$ & $<1.0$ & $<1.0$ & $<1.0$ & 2.8 & $<1.0$ & 63 & 46 \\
\hline & $07-27-99$ & $<1.0$ & $<1.0$ & $<1.0$ & $<1.0$ & 1.1 & $<1.0$ & 43 & 44 \\
\hline & 09-09-99 & $<1.0$ & $<1.0$ & $<1.0$ & $<1.0$ & 1.2 & $<1.0$ & 36 & 31 \\
\hline & $10-20-99$ & $<2.6$ & $<2.0$ & .15 & $<1.0$ & $<1.0$ & $<1.0$ & 37 & 43 \\
\hline & $01-12-00$ & $<2.6$ & $<2.0$ & .30 & $<1.0$ & e.59 & $<1.0$ & 65 & 76 \\
\hline & $02-29-00$ & $<2.6$ & $<.90$ & .40 & $<1.0$ & 1.4 & $<1.0$ & 69 & 75 \\
\hline & $03-28-00$ & $<2.6$ & $<.90$ & .32 & $<1.0$ & e.74 & $<1.0$ & 81 & 80 \\
\hline & $04-11-00$ & $<2.6$ & $<.90$ & .37 & $<1.0$ & 2.1 & $<1.0$ & 96 & 81 \\
\hline & $04-18-00$ & $<2.6$ & $<.90$ & .44 & $<1.0$ & 5.6 & $<1.0$ & 92 & 71 \\
\hline & $05-03-00$ & $<2.6$ & $<2.0$ & .29 & $<1.0$ & 7.8 & 1.6 & 67 & 56 \\
\hline & $05-16-00$ & $<2.6$ & $<.90$ & .26 & $<1.0$ & 3.6 & $<1.0$ & 62 & 46 \\
\hline & $05-31-00$ & $<2.6$ & $<.90$ & .21 & $<1.0$ & 2.1 & $<1.0$ & 63 & 51 \\
\hline & $06-27-00$ & $<2.6$ & $<.90$ & .15 & $<1.0$ & 1.1 & $<1.0$ & 47 & 38 \\
\hline & $07-25-00$ & $<2.6$ & $<.90$ & .13 & $<1.0$ & 1.1 & $<1.0$ & e29 & 38 \\
\hline & $08-30-00$ & $<2.6$ & e. 50 & $<.11$ & $<1.0$ & 1.3 & $<1.0$ & e26 & 22 \\
\hline & $11-08-00$ & $<1.9$ & .44 & .18 & .14 & $<1.0$ & .13 & 46 & 45 \\
\hline & $12-21-00$ & $<2.6$ & .47 & .23 & .20 & $<1.0$ & .17 & 68 & 66 \\
\hline & $01-22-01$ & $<1.9$ & .53 & .22 & .19 & $<1.0$ & .15 & 60 & 66 \\
\hline & 03-13-01 & $<1.9$ & .45 & .23 & .18 & $<1.0$ & .16 & 66 & 65 \\
\hline & 04-09-01 & $<1.9$ & .40 & .21 & .18 & $<1.0$ & e.04 & 65 & 61 \\
\hline & $05-07-01$ & $<1.9$ & .38 & .29 & .22 & 1.9 & .41 & 71 & 60 \\
\hline & 06-11-01 & $<1.9$ & .39 & .22 & .16 & 1.5 & .17 & 51 & 46 \\
\hline & 08-13-01 & $<1.9$ & .57 & .11 & .08 & 1.0 & .12 & 30 & 28 \\
\hline & 08-14-01 & $<1.9$ & .59 & .10 & .10 & 1.1 & .13 & 33 & 30 \\
\hline \multirow[t]{7}{*}{ Well 1} & $08-08-00$ & -- & $<.90$ & -- & $<1.0$ & -- & $<1.0$ & -- & $<1.0$ \\
\hline & $09-27-00$ & -- & $<.90$ & -- & $<1.0$ & -- & $<1.0$ & -- & $<1.0$ \\
\hline & $12-15-00$ & -- & e. 17 & -- & $<.04$ & -- & $<.08$ & -- & 1.3 \\
\hline & $03-28-01$ & -- & e. 12 & -- & $<.04$ & -- & $<.08$ & -- & $<1.0$ \\
\hline & $05-03-01$ & -- & e.09 & -- & $<.04$ & -- & $<.08$ & -- & $<1.0$ \\
\hline & $05-23-01$ & -- & e. 10 & -- & $<.04$ & -- & $<.08$ & -- & $<1.0$ \\
\hline & 08-14-01 & $<2.0$ & e. 13 & $<.04$ & $<.04$ & $<1.0$ & $<.08$ & 1.7 & $<1.0$ \\
\hline
\end{tabular}


Table 8. Selected trace-element concentrations of the Spokane River at Post Falls, Idaho, and ground water from monitoring wells within the Spokane Valley/Rathdrum Prairie aquifer, 1999-2001-Continued

[e, estimated; $\mu \mathrm{g} / \mathrm{L}$, micrograms per liter; <, less than; --, no data]

\begin{tabular}{|c|c|c|c|c|c|c|c|c|c|}
\hline $\begin{array}{l}\text { Site } 1 / \text { well } \\
\text { number }\end{array}$ & Date & $\begin{array}{l}\text { Arsenic } \\
\text { total } \\
\text { recover- } \\
\text { able } \\
\text { ( } \mu \mathrm{g} / \mathrm{L} \text { as } \\
\text { As) }\end{array}$ & $\begin{array}{c}\text { Arsenic, } \\
\text { dissolved } \\
(\mu \mathrm{g} / \mathrm{L} \text { as } \\
\text { As })\end{array}$ & $\begin{array}{l}\text { Cadmium, } \\
\text { total } \\
\text { recover- } \\
\text { able } \\
\text { ( } \mu \mathrm{g} / \mathrm{L} \text { as } \\
\text { Cd) }\end{array}$ & $\begin{array}{c}\text { Cadmium, } \\
\text { dissolved } \\
(\mu \mathrm{g} / \mathrm{L} \text { as } \\
\text { Cd })\end{array}$ & $\begin{array}{l}\text { Lead, total } \\
\text { recover- } \\
\text { able } \\
(\mu \mathrm{g} / \mathrm{L} \text { as } \\
\mathrm{Pb})\end{array}$ & $\begin{array}{c}\text { Lead, } \\
\text { dissolved } \\
(\mu \mathrm{g} / \mathrm{L} \text { as } \\
\mathrm{Pb})\end{array}$ & $\begin{array}{c}\text { Zinc, total } \\
\text { recover- } \\
\text { able } \\
(\mu \mathrm{g} / \mathrm{L} \text { as } \\
\mathrm{Zn})\end{array}$ & $\begin{array}{c}\text { Zinc, } \\
\text { dissolved } \\
(\mu \mathrm{g} / \mathrm{L} \text { as } \\
\mathrm{Zn})\end{array}$ \\
\hline \multirow[t]{8}{*}{ Well 2} & $09-27-00$ & -- & $<0.90$ & -- & $<1.0$ & -- & $<1.0$ & -- & 54 \\
\hline & $12-15-00$ & -- & .36 & -- & .35 & -- & .12 & -- & 61 \\
\hline & 03-28-01 & -- & .31 & -- & .32 & -- & .09 & -- & 56 \\
\hline & 04-30-01 & -- & .32 & -- & .36 & -- & .09 & -- & 63 \\
\hline & 05-03-01 & -- & .27 & -- & .36 & -- & .11 & -- & 60 \\
\hline & 05-03-01 & -- & .30 & -- & .37 & -- & .12 & -- & 61 \\
\hline & $05-23-01$ & -- & .38 & -- & .40 & -- & .12 & -- & 71 \\
\hline & 08-14-01 & $<2.0$ & .48 & .70 & .68 & 2.6 & $<.08$ & 74 & 66 \\
\hline \multirow[t]{5}{*}{ Well 3} & $10-04-00$ & -- & 4.4 & -- & e. 03 & -- & $<.08$ & -- & $<1.0$ \\
\hline & $12-20-00$ & -- & 4.3 & -- & $<.04$ & -- & $<.08$ & -- & $<1.0$ \\
\hline & 05-01-01 & -- & 4.1 & -- & $<.04$ & -- & $<.08$ & -- & $<1.0$ \\
\hline & $05-23-01$ & -- & 4.4 & -- & $<.04$ & -- & $<.08$ & -- & $<1.0$ \\
\hline & 08-14-01 & -- & 4.0 & -- & $<.04$ & -- & $<.08$ & -- & $<1.0$ \\
\hline \multirow[t]{8}{*}{ Well 4} & 06-19-00 & -- & 1.3 & -- & $<1.0$ & -- & $<1.0$ & -- & 25 \\
\hline & $08-07-00$ & $<2.6$ & e. 52 & $<1.0$ & $<1.0$ & $<1.0$ & $<1.0$ & 35 & 34 \\
\hline & $09-25-00$ & -- & $<.90$ & -- & $<1.0$ & -- & $<1.0$ & -- & 38 \\
\hline & $12-14-00$ & -- & .28 & -- & .30 & -- & e. 05 & -- & 43 \\
\hline & 03-26-01 & -- & .32 & -- & .33 & -- & $<.08$ & -- & 46 \\
\hline & 04-30-01 & -- & .42 & -- & .33 & -- & $<.08$ & -- & 49 \\
\hline & $05-22-01$ & -- & .38 & -- & .35 & -- & $<.08$ & -- & 49 \\
\hline & $08-13-01$ & $<2.0$ & .42 & .45 & .42 & $<1.0$ & $<.08$ & 46 & 42 \\
\hline \multirow[t]{7}{*}{ Well 5} & 06-19-00 & -- & e.83 & -- & $<1.0$ & -- & $<1.0$ & -- & 25 \\
\hline & $08-07-00$ & $<2.6$ & $<.90$ & $<1.0$ & $<1.0$ & $<1.0$ & $<1.0$ & 22 & 21 \\
\hline & $09-26-00$ & -- & $<.90$ & -- & $<1.0$ & -- & $<1.0$ & -- & 24 \\
\hline & 03-26-01 & -- & .30 & -- & .26 & -- & $<.08$ & -- & 34 \\
\hline & 04-30-01 & -- & .37 & -- & .27 & -- & $<.08$ & -- & 36 \\
\hline & $05-22-01$ & -- & .36 & -- & .31 & -- & $<.08$ & -- & 41 \\
\hline & 08-13-01 & $<2.0$ & .37 & .33 & .28 & 1.5 & $<.08$ & 36 & 29 \\
\hline \multirow[t]{7}{*}{ Well 6} & $08-07-00$ & -- & e. 48 & -- & $<1.0$ & -- & $<1.0$ & -- & 29 \\
\hline & $09-26-00$ & -- & $<.90$ & -- & $<1.0$ & -- & $<1.0$ & -- & 29 \\
\hline & $12-14-00$ & -- & .27 & -- & .33 & -- & $<.08$ & -- & 34 \\
\hline & $03-26-01$ & -- & .21 & -- & .32 & -- & $<.08$ & -- & 35 \\
\hline & 04-30-01 & -- & .27 & -- & .29 & -- & $<.08$ & -- & 42 \\
\hline & $05-22-01$ & -- & .33 & -- & .32 & -- & $<.08$ & -- & 38 \\
\hline & $08-13-01$ & $<2.0$ & .37 & .38 & .34 & $<1.0$ & $<.08$ & 41 & 32 \\
\hline
\end{tabular}


Table 8. Selected trace-element concentrations of the Spokane River at Post Falls, Idaho, and ground water from monitoring wells within the Spokane Valley/Rathdrum Prairie aquifer, 1999-2001-Continued

[e, estimated; $\mu \mathrm{g} / \mathrm{L}$, micrograms per liter; <, less than; --, no data]

\begin{tabular}{|c|c|c|c|c|c|c|c|c|c|}
\hline $\begin{array}{l}\text { Site } 1 / \text { well } \\
\text { number }^{2}\end{array}$ & Date & $\begin{array}{c}\text { Arsenic } \\
\text { total } \\
\text { recover- } \\
\text { able } \\
\text { ( } \mu \mathrm{g} / \mathrm{L} \text { as } \\
\text { As) }\end{array}$ & $\begin{array}{c}\text { Arsenic, } \\
\text { dissolved } \\
(\mu \mathrm{g} / \mathrm{L} \text { as } \\
\text { As })\end{array}$ & $\begin{array}{l}\text { Cadmium, } \\
\text { total } \\
\text { recover- } \\
\text { able } \\
(\mu \mathrm{g} / \mathrm{L} \text { as } \\
\text { Cd) }\end{array}$ & $\begin{array}{c}\text { Cadmium, } \\
\text { dissolved } \\
(\mu \mathrm{g} / \mathrm{L} \text { as } \\
\text { Cd })\end{array}$ & $\begin{array}{l}\text { Lead, total } \\
\text { recover- } \\
\text { able } \\
(\mu \mathrm{g} / \mathrm{L} \text { as } \\
\mathrm{Pb})\end{array}$ & $\begin{array}{l}\text { Lead, } \\
\text { dissolved } \\
(\mu \mathrm{g} / \mathrm{L} \text { as } \\
\mathrm{Pb})\end{array}$ & $\begin{array}{c}\text { Zinc, total } \\
\text { recover- } \\
\text { able } \\
(\mu \mathrm{g} / \mathrm{L} \text { as } \\
\mathrm{Zn})\end{array}$ & $\begin{array}{c}\text { Zinc, } \\
\text { dissolved } \\
(\mu \mathrm{g} / \mathrm{L} \text { as } \\
\mathrm{Zn})\end{array}$ \\
\hline \multirow[t]{7}{*}{ Well 7} & 08-08-00 & -- & $\mathrm{e} 0.52$ & -- & $<1.0$ & -- & $<1.0$ & -- & $<1.0$ \\
\hline & $09-27-00$ & -- & e. 47 & -- & $<1.0$ & -- & $<1.0$ & -- & $<1.0$ \\
\hline & $12-14-00$ & -- & .45 & -- & $<.04$ & -- & e.06 & -- & $<1.0$ \\
\hline & 03-26-01 & -- & .37 & -- & $<.04$ & -- & $<.08$ & -- & $<1.0$ \\
\hline & 04-30-01 & -- & .50 & -- & $<.04$ & -- & $<.08$ & -- & $<1.0$ \\
\hline & $05-22-01$ & -- & .45 & -- & $<.04$ & -- & $<.08$ & -- & 6.8 \\
\hline & 08-14-01 & -- & .42 & -- & $<.04$ & -- & $<.08$ & -- & $<1.0$ \\
\hline \multirow[t]{9}{*}{ Well 8} & $07-12-00$ & -- & e. 45 & $<1.0$ & $<1.0$ & $<1.0$ & $<1.0$ & 31 & 26 \\
\hline & 08-09-00 & $<2.6$ & $<.90$ & $<1.0$ & $<1.0$ & $<1.0$ & $<1.0$ & 34 & 32 \\
\hline & $09-26-00$ & -- & $<.90$ & -- & $<1.0$ & -- & $<1.0$ & -- & 33 \\
\hline & $12-14-00$ & -- & .46 & -- & .18 & -- & e. 07 & -- & 53 \\
\hline & 03-28-01 & -- & .35 & -- & .21 & -- & .13 & -- & 54 \\
\hline & $05-02-01$ & $<1.9$ & .30 & .24 & .21 & 1.3 & e.06 & 62 & 56 \\
\hline & $05-23-01$ & -- & .44 & -- & .24 & -- & e.06 & -- & 62 \\
\hline & 08-13-01 & $<2.0$ & .54 & .22 & .20 & $<1.0$ & $<.08$ & 35 & 32 \\
\hline & 08-14-01 & $<2.0$ & .52 & .22 & .19 & $<1.0$ & $<.08$ & 43 & 31 \\
\hline \multirow[t]{8}{*}{ Well 9} & 08-09-00 & $<2.6$ & e.47 & $<1.0$ & $<1.0$ & $<1.0$ & $<1.0$ & 22 & 22 \\
\hline & $09-26-00$ & -- & $<.90$ & -- & $<1.0$ & -- & $<1.0$ & -- & 23 \\
\hline & $12-14-00$ & -- & .39 & -- & .16 & -- & e.07 & -- & 45 \\
\hline & 03-28-01 & -- & .30 & -- & .15 & -- & $<.08$ & -- & 41 \\
\hline & $05-02-01$ & -- & .28 & -- & .17 & -- & e.07 & -- & 45 \\
\hline & $05-23-01$ & -- & .38 & -- & .18 & -- & e. 05 & -- & 48 \\
\hline & 08-13-01 & $<2.0$ & .51 & .16 & .15 & $<1.0$ & $<.08$ & 26 & 24 \\
\hline & 08-14-01 & $<2.0$ & .45 & .16 & .13 & $<1.0$ & $<.08$ & 24 & 23 \\
\hline \multirow[t]{7}{*}{ Well 10} & 08-09-00 & -- & e. 46 & -- & $<1.0$ & -- & $<1.0$ & -- & 14 \\
\hline & 09-26-00 & -- & $<.90$ & -- & $<1.0$ & -- & $<1.0$ & -- & 15 \\
\hline & $12-14-00$ & -- & .30 & -- & .09 & -- & $<.08$ & -- & 19 \\
\hline & 03-28-01 & -- & .29 & -- & .09 & -- & $<.08$ & -- & 20 \\
\hline & $05-02-01$ & -- & e. 18 & -- & .24 & -- & $<.08$ & -- & 40 \\
\hline & $05-23-01$ & -- & .33 & -- & .11 & -- & $<.08$ & -- & 25 \\
\hline & 08-13-01 & $<2.0$ & .39 & .16 & .10 & $<1.0$ & $<.08$ & 23 & 16 \\
\hline
\end{tabular}


Table 8. Selected trace-element concentrations of the Spokane River at Post Falls, Idaho, and ground water from monitoring wells within the Spokane Valley/Rathdrum Prairie aquifer, 1999-2001-Continued

[e, estimated; $\mu \mathrm{g} / \mathrm{L}$, micrograms per liter; <, less than; --, no data]

\begin{tabular}{|c|c|c|c|c|c|c|c|c|c|}
\hline $\begin{array}{l}\text { Site } 1 / \text { well } \\
\text { number }^{2}\end{array}$ & Date & $\begin{array}{c}\text { Arsenic } \\
\text { total } \\
\text { recover- } \\
\text { able } \\
\text { ( } \mu \mathrm{g} / \mathrm{L} \text { as } \\
\text { As) }\end{array}$ & $\begin{array}{c}\text { Arsenic, } \\
\text { dissolved } \\
(\mu \mathrm{g} / \mathrm{L} \text { as } \\
\text { As) }\end{array}$ & $\begin{array}{l}\text { Cadmium, } \\
\text { total } \\
\text { recover- } \\
\text { able } \\
(\mu \mathrm{g} / \mathrm{L} \text { as } \\
\text { Cd) }\end{array}$ & $\begin{array}{c}\text { Cadmium, } \\
\text { dissolved } \\
(\mu \mathrm{g} / \mathrm{L} \text { as } \\
\text { Cd })\end{array}$ & $\begin{array}{l}\text { Lead, total } \\
\text { recover- } \\
\text { able } \\
(\mu \mathrm{g} / \mathrm{L} \text { as } \\
\mathrm{Pb})\end{array}$ & $\begin{array}{c}\text { Lead, } \\
\text { dissolved } \\
(\mu \mathrm{g} / \mathrm{L} \text { as } \\
\mathrm{Pb})\end{array}$ & $\begin{array}{c}\text { Zinc, total } \\
\text { recover- } \\
\text { able } \\
(\mu \mathrm{g} / \mathrm{L} \text { as } \\
\mathrm{Zn})\end{array}$ & $\begin{array}{c}\text { Zinc, } \\
\text { dissolved } \\
\text { ( } \mu \mathrm{g} / \mathrm{L} \text { as } \\
\mathrm{Zn})\end{array}$ \\
\hline \multirow[t]{7}{*}{ Well 11} & 08-09-00 & $<2.6$ & $\mathrm{e} 0.49$ & $<1.0$ & $<1.0$ & $<1.0$ & $<1.0$ & 27 & 23 \\
\hline & $10-04-00$ & -- & .35 & -- & .25 & -- & $<.08$ & -- & 28 \\
\hline & $12-19-00$ & -- & .34 & -- & .22 & -- & e.06 & -- & 40 \\
\hline & $03-27-01$ & -- & .32 & -- & .29 & -- & $<.08$ & -- & 45 \\
\hline & 05-01-01 & $<1.9$ & .39 & .31 & .27 & 2.1 & $<.08$ & 51 & 43 \\
\hline & $05-23-01$ & -- & .40 & -- & $<.30$ & -- & $<.08$ & -- & $<48$ \\
\hline & 08-16-01 & $<2.0$ & .51 & .34 & .27 & 4.2 & $<.08$ & 42 & 27 \\
\hline \multirow[t]{6}{*}{ Well 12} & $10-04-00$ & -- & .51 & -- & .05 & -- & $<.08$ & -- & 4.0 \\
\hline & $12-19-00$ & -- & .31 & -- & .07 & -- & e.06 & -- & 11 \\
\hline & $03-27-01$ & -- & .27 & -- & .12 & -- & $<.08$ & -- & 18 \\
\hline & 05-01-01 & $<1.9$ & .28 & .10 & .10 & $<1.0$ & $<.08$ & 18 & 18 \\
\hline & $05-23-01$ & -- & .34 & -- & .10 & -- & $<.08$ & -- & 18 \\
\hline & 08-16-01 & $<2.0$ & .43 & .11 & .08 & $<1.0$ & $<.08$ & 12 & 8.4 \\
\hline \multirow[t]{7}{*}{ Well 13} & 08-09-00 & $<2.6$ & e. 46 & $<1.0$ & $<1.0$ & $<1.0$ & $<1.0$ & 14 & 12 \\
\hline & $10-04-00$ & -- & .39 & -- & .12 & -- & $<.08$ & -- & 13 \\
\hline & $12-19-00$ & -- & .20 & -- & .08 & -- & 1.6 & -- & 12 \\
\hline & $03-27-01$ & -- & e. 17 & -- & .08 & -- & $<.08$ & -- & 10 \\
\hline & 05-01-01 & $<1.9$ & .23 & .15 & .15 & $<1.0$ & $<.08$ & 23 & 23 \\
\hline & $05-23-01$ & -- & .30 & -- & .18 & -- & e. 04 & -- & 25 \\
\hline & 08-16-01 & $<2.0$ & .47 & .16 & .15 & $<1.0$ & $<.08$ & 15 & 14 \\
\hline \multirow[t]{6}{*}{ Well 14} & $10-03-00$ & -- & .37 & -- & $<.04$ & -- & $<.08$ & -- & $<1.0$ \\
\hline & $12-19-00$ & -- & .20 & -- & $<.04$ & -- & 1.1 & -- & $<1.0$ \\
\hline & $03-27-01$ & -- & .21 & -- & $<.04$ & -- & $<.08$ & -- & $<1.0$ \\
\hline & $05-02-01$ & $<1.9$ & e. 17 & $<.04$ & $<.04$ & $<1.0$ & $<.08$ & 1.1 & $<1.0$ \\
\hline & $05-24-01$ & -- & .27 & -- & $<.04$ & -- & $<.08$ & -- & $<1.0$ \\
\hline & $08-15-01$ & $<2.0$ & .47 & $<.04$ & $<.04$ & $<1.0$ & $<.08$ & 1.5 & $<1.0$ \\
\hline \multirow[t]{7}{*}{ Well 15} & $08-10-00$ & -- & 4.6 & -- & $<1.0$ & -- & $<1.0$ & -- & $<1.0$ \\
\hline & $10-03-00$ & -- & 4.5 & -- & .15 & -- & e. 05 & -- & $<1.0$ \\
\hline & $12-19-00$ & -- & 4.3 & -- & $<.04$ & -- & $<.08$ & -- & $<1.0$ \\
\hline & 03-28-01 & -- & 3.6 & -- & $<.04$ & -- & $<.08$ & -- & $<1.0$ \\
\hline & 05-02-01 & 4.8 & 4.0 & $<.04$ & $<.04$ & $<1.0$ & $<.08$ & $<1.0$ & $<1.0$ \\
\hline & $05-24-01$ & -- & 4.2 & -- & $<.04$ & -- & $<.08$ & -- & $<1.0$ \\
\hline & 08-13-01 & 4.6 & 4.2 & .04 & e. 02 & $<1.0$ & $<.08$ & 1.1 & $<1.0$ \\
\hline
\end{tabular}


Table 8. Selected trace-element concentrations of the Spokane River at Post Falls, Idaho, and ground water from monitoring wells within the Spokane Valley/Rathdrum Prairie aquifer, 1999-2001-Continued

[e, estimated; $\mu \mathrm{g} / \mathrm{L}$, micrograms per liter; <, less than; --, no data]

\begin{tabular}{|c|c|c|c|c|c|c|c|c|c|}
\hline $\begin{array}{l}\text { Site } 1 / \text { well } \\
\text { number }^{2}\end{array}$ & Date & $\begin{array}{c}\text { Arsenic } \\
\text { total } \\
\text { recover- } \\
\text { able } \\
\text { ( } \mu \mathrm{g} / \mathrm{L} \text { as } \\
\text { As) }\end{array}$ & $\begin{array}{c}\text { Arsenic, } \\
\text { dissolved } \\
\text { ( } \mu \mathrm{g} / \mathrm{L} \text { as } \\
\text { As) }\end{array}$ & $\begin{array}{l}\text { Cadmium, } \\
\text { total } \\
\text { recover- } \\
\text { able } \\
(\mu \mathrm{g} / \mathrm{L} \text { as } \\
\text { Cd) }\end{array}$ & $\begin{array}{c}\text { Cadmium, } \\
\text { dissolved } \\
(\mu \mathrm{g} / \mathrm{L} \text { as } \\
\text { Cd })\end{array}$ & $\begin{array}{l}\text { Lead, total } \\
\text { recover- } \\
\text { able } \\
(\mu \mathrm{g} / \mathrm{L} \text { as } \\
\mathrm{Pb})\end{array}$ & $\begin{array}{l}\text { Lead, } \\
\text { dissolved } \\
(\mu \mathrm{g} / \mathrm{L} \text { as } \\
\mathrm{Pb})\end{array}$ & $\begin{array}{c}\text { Zinc, total } \\
\text { recover- } \\
\text { able } \\
(\mu \mathrm{g} / \mathrm{L} \text { as } \\
\mathrm{Zn})\end{array}$ & $\begin{array}{c}\text { Zinc, } \\
\text { dissolved } \\
(\mu \mathrm{g} / \mathrm{L} \text { as } \\
\mathrm{Zn})\end{array}$ \\
\hline \multirow[t]{6}{*}{ Well 16} & $08-10-00$ & 3.0 & 3.1 & $<1.0$ & $<1.0$ & $<1.0$ & $<1.0$ & $<1.0$ & $<1.0$ \\
\hline & $10-04-00$ & -- & 2.9 & -- & $<.04$ & -- & $<.08$ & -- & $<1.0$ \\
\hline & $12-19-00$ & -- & 3.1 & -- & $<.04$ & -- & $<.08$ & -- & $<1.0$ \\
\hline & 05-01-01 & -- & 3.4 & -- & $<.04$ & -- & .10 & -- & $<1.0$ \\
\hline & 05-23-01 & -- & 3.0 & -- & $<.04$ & -- & $<.08$ & -- & $<1.0$ \\
\hline & $08-15-01$ & -- & 2.9 & -- & $<.04$ & -- & e.08 & -- & 2.3 \\
\hline \multirow[t]{7}{*}{ Well 17} & 08-08-00 & -- & $<.90$ & -- & $<1.0$ & -- & $<1.0$ & -- & $<1.0$ \\
\hline & $10-03-00$ & -- & .32 & -- & $<.04$ & -- & $<.08$ & -- & $<1.0$ \\
\hline & $12-14-00$ & -- & .28 & -- & $<.04$ & -- & $<.08$ & -- & 1.2 \\
\hline & 03-27-01 & -- & .29 & -- & $<.04$ & -- & $<.08$ & -- & $<1.0$ \\
\hline & $05-01-01$ & -- & .32 & -- & $<.04$ & -- & $<.08$ & -- & $<1.0$ \\
\hline & $05-22-01$ & -- & .30 & -- & $<.04$ & -- & $<.08$ & -- & $<1.0$ \\
\hline & 08-15-01 & -- & .28 & -- & $<.04$ & -- & 1.0 & -- & $<1.0$ \\
\hline \multirow[t]{7}{*}{ Well 18} & 08-08-00 & -- & $<.90$ & -- & $<1.0$ & -- & $<1.0$ & -- & $<1.0$ \\
\hline & $10-03-00$ & -- & .31 & -- & $<.04$ & -- & $<.08$ & -- & $<1.0$ \\
\hline & $12-19-00$ & -- & .20 & -- & $<.04$ & -- & $<.08$ & -- & $<1.0$ \\
\hline & 03-27-01 & -- & e. 17 & -- & $<.04$ & -- & $<.08$ & -- & $<1.0$ \\
\hline & 05-01-01 & -- & .24 & -- & $<.04$ & -- & $<.08$ & -- & $<1.0$ \\
\hline & $05-22-01$ & -- & e. 17 & -- & $<.04$ & -- & $<.08$ & -- & $<1.0$ \\
\hline & 08-15-01 & -- & .22 & -- & $<.04$ & -- & $<.08$ & -- & $<1.0$ \\
\hline \multirow[t]{7}{*}{ Well 19} & $08-08-00$ & -- & $<.90$ & -- & $<1.0$ & -- & $<1.0$ & -- & 8.9 \\
\hline & $10-03-00$ & -- & .52 & -- & .09 & -- & $<.08$ & -- & 9.9 \\
\hline & 12-19-00 & -- & .25 & -- & .07 & -- & .34 & -- & 9.3 \\
\hline & 03-27-01 & -- & .23 & -- & .16 & -- & $<.08$ & -- & 19 \\
\hline & $05-01-01$ & -- & .38 & -- & .06 & -- & e.04 & -- & 12 \\
\hline & $05-22-01$ & -- & .26 & -- & .26 & -- & $<.08$ & -- & 26 \\
\hline & $08-15-01$ & $<2.0$ & .35 & .17 & .16 & $<1.0$ & $<.08$ & 20 & 20 \\
\hline \multirow[t]{6}{*}{ Well 20} & $10-05-00$ & -- & .94 & -- & $<.04$ & -- & $<.08$ & -- & $<1.0$ \\
\hline & $12-20-00$ & -- & 1.0 & -- & $<.04$ & -- & .23 & -- & $<1.0$ \\
\hline & 03-29-01 & -- & 1.0 & -- & $<.04$ & -- & $<.08$ & -- & $<1.0$ \\
\hline & $05-02-01$ & -- & .98 & -- & $<.04$ & -- & $<.08$ & -- & $<1.0$ \\
\hline & $05-21-01$ & -- & 1.0 & -- & $<.04$ & -- & $<.08$ & -- & 1.1 \\
\hline & $08-15-01$ & -- & 1.1 & -- & $<.04$ & -- & $<.08$ & -- & $<1.0$ \\
\hline
\end{tabular}


Table 8. Selected trace-element concentrations of the Spokane River at Post Falls, Idaho, and ground water from monitoring wells within the Spokane Valley/Rathdrum Prairie aquifer, 1999-2001-Continued

[e, estimated; $\mu \mathrm{g} / \mathrm{L}$, micrograms per liter; <, less than; --, no data]

\begin{tabular}{|c|c|c|c|c|c|c|c|c|c|}
\hline $\begin{array}{l}\text { Site } 1 / \text { well } \\
\text { number }^{2}\end{array}$ & Date & $\begin{array}{l}\text { Arsenic } \\
\text { total } \\
\text { recover- } \\
\text { able } \\
\text { ( } \mu \mathrm{g} / \mathrm{L} \text { as } \\
\text { As) }\end{array}$ & $\begin{array}{l}\text { Arsenic, } \\
\text { dissolved } \\
(\mu \mathrm{g} / \mathrm{L} \text { as } \\
\text { As })\end{array}$ & $\begin{array}{l}\text { Cadmium, } \\
\text { total } \\
\text { recover- } \\
\text { able } \\
(\mu \mathrm{g} / \mathrm{L} \text { as } \\
\text { Cd) }\end{array}$ & $\begin{array}{c}\text { Cadmium, } \\
\text { dissolved } \\
(\mu \mathrm{g} / \mathrm{L} \text { as } \\
\text { Cd })\end{array}$ & $\begin{array}{l}\text { Lead, total } \\
\text { recover- } \\
\text { able } \\
(\mu \mathrm{g} / \mathrm{L} \text { as } \\
\mathrm{Pb})\end{array}$ & $\begin{array}{l}\text { Lead, } \\
\text { dissolved } \\
\text { ( } \mu \mathrm{g} / \mathrm{L} \text { as } \\
\mathrm{Pb})\end{array}$ & $\begin{array}{c}\text { Zinc, total } \\
\text { recover- } \\
\text { able } \\
(\mu \mathrm{g} / \mathrm{L} \text { as } \\
\mathrm{Zn})\end{array}$ & $\begin{array}{c}\text { Zinc, } \\
\text { dissolved } \\
\text { ( } \mu \mathrm{g} / \mathrm{L} \text { as } \\
\mathrm{Zn})\end{array}$ \\
\hline \multirow[t]{6}{*}{ Well 21} & $10-05-00$ & -- & 0.27 & -- & 0.06 & -- & $<0.08$ & -- & 10 \\
\hline & $12-20-00$ & -- & .29 & -- & $<.04$ & -- & .14 & -- & 1.6 \\
\hline & 03-29-01 & -- & .22 & -- & $<.04$ & -- & $<.08$ & -- & 3.7 \\
\hline & $05-03-01$ & -- & .12 & -- & .15 & -- & $<.08$ & -- & 11 \\
\hline & $05-21-01$ & -- & e. 18 & -- & .04 & -- & $<.08$ & -- & 12 \\
\hline & $08-15-01$ & $<2.0$ & .22 & .06 & .05 & $<1.0$ & $<.08$ & 12 & 9.8 \\
\hline \multirow[t]{6}{*}{ Well 22} & $10-05-00$ & -- & .33 & -- & .21 & -- & $<.08$ & -- & 27 \\
\hline & $12-20-00$ & -- & .25 & -- & .13 & -- & $<.08$ & -- & 19 \\
\hline & 03-29-01 & -- & .22 & -- & .27 & -- & $<.08$ & -- & 43 \\
\hline & 05-03-01 & -- & .28 & -- & .08 & -- & $<.08$ & -- & 21 \\
\hline & $05-21-01$ & -- & .21 & -- & .25 & -- & $<.08$ & -- & 42 \\
\hline & 08-15-01 & $<2.0$ & .20 & .15 & .12 & $<1.0$ & $<.08$ & 18 & 17 \\
\hline \multirow[t]{6}{*}{ Well 23} & $10-05-00$ & -- & .35 & -- & .41 & -- & $<.08$ & -- & 42 \\
\hline & $12-20-00$ & -- & .22 & -- & .41 & -- & .09 & -- & 48 \\
\hline & 03-29-01 & -- & .24 & -- & .46 & -- & e.04 & -- & 60 \\
\hline & $05-03-01$ & -- & .21 & -- & .42 & -- & e.05 & -- & 53 \\
\hline & $05-21-01$ & -- & .33 & -- & .39 & -- & $<.08$ & -- & 49 \\
\hline & $08-15-01$ & $<2.0$ & .49 & .50 & .52 & $<1.0$ & $<.08$ & 44 & 44 \\
\hline \multirow[t]{6}{*}{ Well 24} & $10-05-00$ & -- & 1.7 & -- & $<.04$ & -- & $<.08$ & -- & $<1.0$ \\
\hline & $12-20-00$ & -- & 1.8 & -- & $<.04$ & -- & e. 04 & -- & $<1.0$ \\
\hline & 03-29-01 & -- & 2.0 & -- & $<.04$ & -- & e. 07 & -- & $<1.0$ \\
\hline & 05-03-01 & -- & 1.8 & -- & $<.04$ & -- & $<.08$ & -- & $<1.0$ \\
\hline & $05-21-01$ & -- & 2.0 & -- & $<.04$ & -- & $<.08$ & -- & $<1.0$ \\
\hline & $08-15-01$ & -- & 1.8 & -- & $<.04$ & -- & $<.08$ & -- & $<1.0$ \\
\hline \multirow[t]{6}{*}{ Well 25} & $10-04-00$ & -- & 2.4 & -- & $<.04$ & -- & $<.08$ & -- & $<1.0$ \\
\hline & $12-20-00$ & -- & 2.0 & -- & $<.04$ & -- & $<.08$ & -- & $<1.0$ \\
\hline & 03-29-01 & -- & 2.6 & -- & $<.04$ & -- & e. 07 & -- & 1.2 \\
\hline & $05-02-01$ & -- & 3.2 & -- & $<.04$ & -- & e. 05 & -- & 1.8 \\
\hline & $05-21-01$ & -- & 2.6 & -- & $<.04$ & -- & $<.08$ & -- & $<1.0$ \\
\hline & 08-14-01 & 3.0 & 2.7 & $<.04$ & $<.04$ & $<1.0$ & $<.08$ & $<1.0$ & $<1.0$ \\
\hline
\end{tabular}

${ }^{1}$ Spokane River sampled at Post Falls, Idaho (station 12419000).

${ }^{2}$ Number corresponds to wells listed in table 1 and shown in figure 3. 